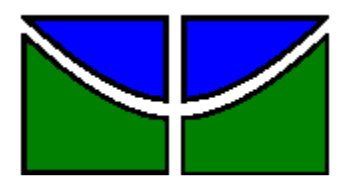

Universidade de Brasília

Faculdade de Administração, Contabilidade, Economia e Gestão de Políticas Públicas Departamento de Gestão de Políticas Públicas

GIULLIO CÉSAR DA SILVA BARBOSA

O FENÔMENO DA INSERÇÃO ESTRATÉGICA DA ÁREA DE GESTÃO DE PESSOAS: ALINHAMENTO ENTRE POLÍTICAS E PRÁTICAS DE GESTÃo ESTRATÉGICA E AS DIRETRIZES ORGANIZACIONAIS

Brasília - DF

2019 


\section{GIULLIO CÉSAR DA SILVA BARBOSA}

\section{O FENÔMENO DA INSERÇÃO ESTRATÉGICA DA ÁREA DE GESTÃO DE PESSOAS: ALINHAMENTO ENTRE POLÍTICAS E PRÁTICAS DE GESTÃo ESTRATÉGICA E AS DIRETRIZES ORGANIZACIONAIS}

Monografia apresentada ao

Departamento de Gestão de Políticas

Públicas como requisito parcial à obtenção do título de Bacharel em Gestão de Políticas Públicas.

Professor Orientador: Doutor Pedro

Paulo Murce Meneses

Brasília - DF 


\title{
O FENÔMENO DA INSERÇÃO ESTRATÉGICA DA ÁREA DE GESTÃO DE PESSOAS: ALINHAMENTO ENTRE POLÍTICAS E PRÁTICAS DE GESTÃo ESTRATÉGICA E AS DIRETRIZES ORGANIZACIONAIS
}

\begin{abstract}
A Comissão Examinadora, abaixo identificada, aprova o Trabalho de Conclusão do Curso de Gestão de Políticas Públicas da Universidade de Brasília do aluno
\end{abstract}

\section{GIULLIO CÉSAR DA SILVA BARBOSA}

Doutor, Pedro Paulo Murce Meneses

Professor-Orientador

$$
\begin{aligned}
& \text { Doutora, Suylan de Almeida Midlej e Silva } \\
& \text { Professora-Examinadora }
\end{aligned}
$$

Mestre, Diogo Ribeiro da Fonseca Professor-Examinador 


\section{AGRADECIMENTOS}

Agradeço aquele que merece toda honra, glória e louvor. O qual sem Suas forças eu não conseguiria ter realizado todo este trabalho. Todo o esforço empreendido nesta atividade só foi possível graças à Deus. O Criador que me ensina constantemente sobre humildade, assim como priorizar sua criação mais importante: pessoas! Também agradeço à Ele por estes quatro anos e meio de graduação, aos quais - através do temor por Ele, aprendi relevantes ferramentas que serão utilizadas em Sua obra.

Agradeço à toda minha família, que me apoiou e deu suporte nos mínimos detalhes, especialmente minha mãe Nilva que nunca mediu esforços para me proporcionar a melhor educação possível! Também agradeço ao meu irmão Gabriel, que sempre me alimentou com esperanças de fazer um bom trabalho, assim como ótimas risadas para relaxar. Também ao meu pai Luiz, homem reto e honesto que sempre priorizou tomar as decisões corretas.

Ao meu orientador Pedro Meneses, que - no ano deste trabalho, me ensinou não só detalhes de como construir um bom trabalho de conclusão de curso; mas me ensinou particularidades da vida, portanto, se tornando um precioso amigo.

Aos líderes e membros da Comunidade Cristã Videira, que me incentivaram durante toda a jornada deste trabalho, assim como, de maneira bastante amorosa, marcaram presença na apresentação final!

Aos pesquisadores da Projectum, que me auxiliaram nos detalhes técnicos deste trabalho, portanto, sendo cruciais e também merecedores das conquistas desta pesquisa. Em especial quero agradecer à Júlia Cássia e Andréia Miguens, que sanaram dúvidas estruturais do trabalho, da mesma forma que me estimularam a transpassar as barreiras deste exercício.

Agradeço ao professor Diogo Fonseca e professora Suylan Midlej, por aceitarem o convite para banca de avaliação deste trabalho, assim como por suas ricas colocações.

Por fim, agradeço ao meu amigo/irmão João Vitor Paiva, que revisou todo o texto horas antes da entrega deste trabalho para a banca. Amigo este, que se faz irmão nos momentos certos! 


\section{RESUMO}

Os desafios do alinhamento estratégico com as políticas e práticas de Gestão Estratégica de Pessoas envolvem não só aspectos institucionais, organizacionais e setoriais, mas sobretudo políticos. O histórico da administração pública brasileira comprova o quanto interesses políticos sobrepunham escolhas técnicas na tomada de decisão, o que resulta em práticas clientelísticas. Para que a unidade de gestão de pessoas alcance o alinhamento estratégico se faz prioritário sua inserção estratégica nas principais arenas decisórias. O objetivo deste trabalho foi descrever o processo de inserção estratégica da área de Gestão de Pessoas e seus profissionais nas arenas decisórias de duas organizações públicas. Esta pesquisa de caráter qualitativo, coletou dados por meio do levantamento de opiniões. Com base em entrevistas semiestruturadas, foram transcritos relatos dos principais representantes de GP das instituições selecionadas. Através da técnica analise de conteúdo, foi possível identificar que as habilidades políticas do líder de GP constituem fator primordial para o sucesso da inserção estratégica. As habilidades mais empregadas pelo representante de Gestão de Pessoas, foram o Produção e Controle de Informações e a construção de uma rede de interação entre os executivos chave da organização (Networking).

Palavras-chave: Gestão Estratégica de Pessoas. Políticas Públicas. Inserção Estratégica de Pessoas. Administração Pública. Habilidades Politicas do Líder de Gestão de Pessoas. 


\section{Lista de Tabelas}

Tabela 1. Sete principais temas da GEP ........................................................................26

Tabela 2. Síntese das categorias propostas para os fatores interferentes .....................................29

Tabela 3. Fatores estratégicos, estruturais e culturais interferentes na implementação. ...................34

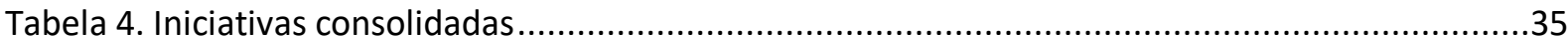

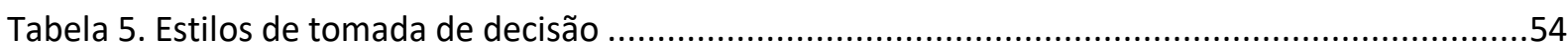

Tabela 6 Especificação dos procedimentos metodológicos da pesquisa ......................................61

Tabela 7 Regras para a categorização na análise de conteúdo ................................................66

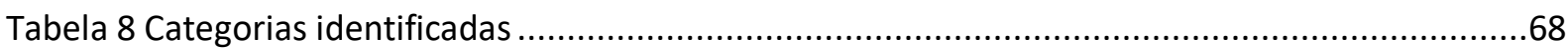

Tabela 9 Conteúdos das políticas abordadas pela área de GP ...............................................70

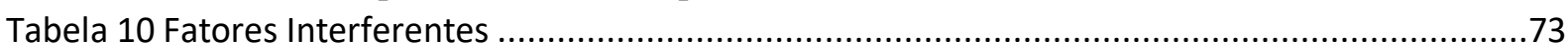

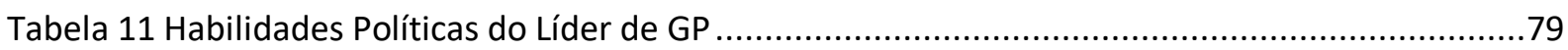




\section{Lista de Figuras}

Figura 1. Modelo simplificado de cadeia de relações entre fatores...........................................31

Figura 2. Modelo lógico das dificuldades enfrentadas. ...............................................................32

Figura 3. Modelo lógico que relaciona as iniciativas implementadas e as dificuldades enfrentadas. ..33

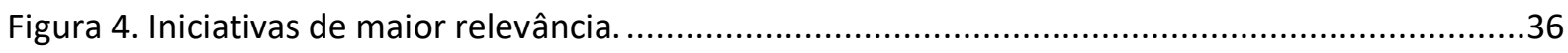

Figura 5. Envolvimento da GP no processo de tomada de decisão. ...........................................41 


\section{Lista de Abreviaturas e Siglas}

APG - Administração Pública Gerencial

CD - Comissão Diretora

DASP - Departamento Administrativo do Serviço Público

DG - Diretoria Geral

GEP - Gestão Estratégica de Pessoas

MARE - Ministério da Administração e da Reforma do Estado

NPM - New Public Management

PDRAE - Plano Diretor da Reforma do Aparelho de Estado

PNDP - Política Nacional de Desenvolvimento de Pessoal

PP - Política Pública 


\section{Sumário}

1. Introdução .................................................................................................................................. 10

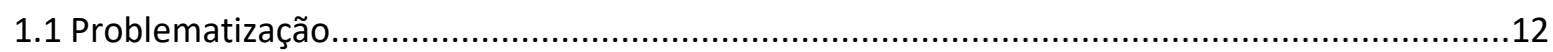

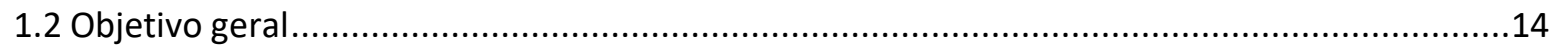

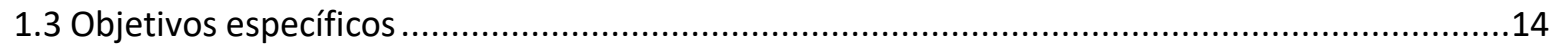

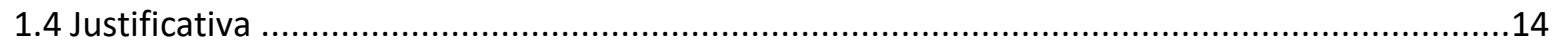

2. Referencial Teórico …………….......................................................................................... 16

2.10 desenvolvimento da administração pública no Brasil: do modelo burocrático ao -

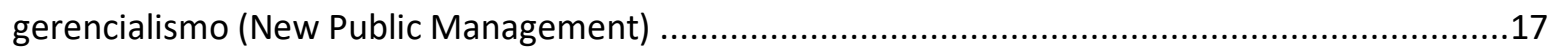

2.2 Gestão Estratégica de Pessoas no Setor Público....................................................................24

2.2.1 Fatores interferentes na implementação da GEP nas organizações públicas .....................28

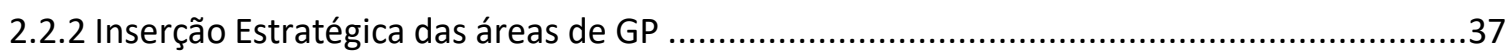

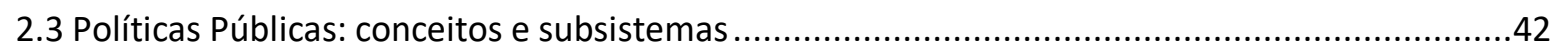

2.3.1 Tomada de decisão e implementação de políticas públicas .................................................48

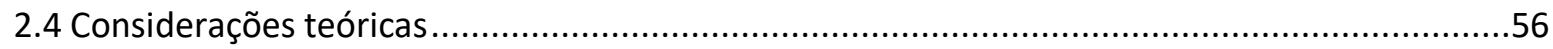

3. Métodos e Técnicas de Pesquisa.................................................................................6 61

3.1 Amostragem

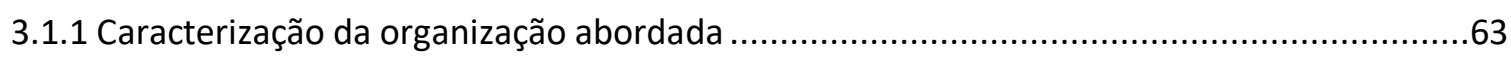

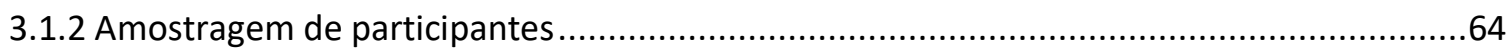

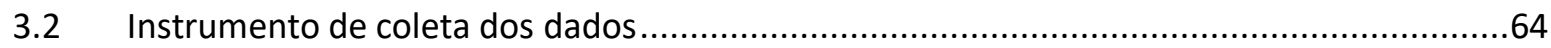

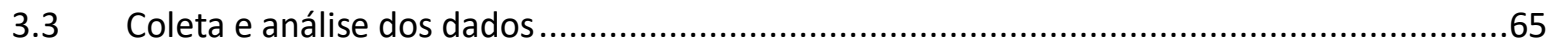

4. Resultados e Discussão ................................................................................................ 68

4.1 Conteúdos das políticas abordadas pela área de gestão de pessoas........................................69

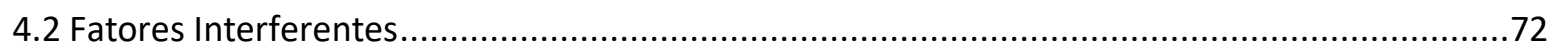

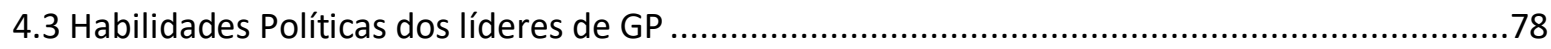

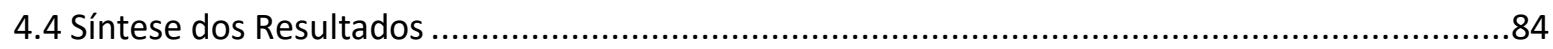

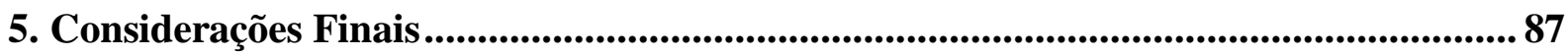

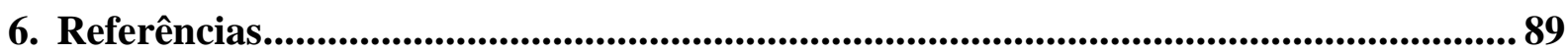

Apêndice A - Roteiro de entrevista semiestruturado ...................................................95

Apêndice B - Carta de Apresentação à Pesquisa.............................................................. 98

Apêndice C - Termo de Consentimento Livre e Esclarecido ........................................ 100 


\section{Introdução}

As reformas administrativas do Estado demonstram incessantes tentativas de sanar problemas da máquina pública provenientes da formação do Estado Nacional. Costa (2008) constrói um panorama histórico das reformas em que, no Estado Novo de 1937, teve-se a primeira tentativa de burocratização do Estado brasileiro advindo da idealização de princípios racionais que conduziram a construção de um sistema centralizado. A impessoalidade, o sistema de mérito, a separação entre público e privado e a hierarquia foram adotados como bases de combate ao patrimonialismo e clientelismo (Costa, 2008; Martins, 1997). Logo percebe-se a necessidade da criação de figuras institucionais que ficariam responsáveis por prover esta nova administração, assim como a implantação de diversos mecanismos de controle com evidência para áreas de pessoal (Costa, 2008). Porém na década de 1990, anos após a primeira tentativa de reforma, o Brasil não conseguiu solucionar o gargalo do patrimonialismo e nem implantar o sistema público burocrático em sua totalidade; fato este acompanhado de crises econômicas, políticas e sociais em âmbito nacional (Bresser, 1997; Costa, 2008).

Surge o New Public Management (NPM) ou administração pública gerencial como proposta de modernização para redução do controle e aumento da flexibilização que, no Brasil, ganhou corpo através do Plano Diretor da Reforma do Aparelho de Estado (PDRAE) do ministro Luiz Carlos Bresser no governo Fernando Henrique Cardoso (Bresser, 1998). O novo modelo propaga o reconhecimento do Estado como reflexo da sociedade, ou seja, a existência do campo de conflito, cooperação e incerteza que se faz presente tanto na sociedade como no setor público; portanto afirmando a extinção parcial da dicotomia entre administração e política pregada por Woodrow Wilson (1887), assim como o novo papel estatal de garantia do interesse coletivo através da definição de práticas administrativas abertas e transparentes (Bresser, 1997).

O debate entorno da aplicação do NPM gerou modelos de avaliação de desempenho, novas formas de controle de orçamento, estruturas de governança, ênfase na qualidade, descentralização da administração de recursos humanos, foco no planejamento coorporativo com metas e objetivos, novas formas de atendimento ao usuário de serviços públicos, estímulo à competitividade e desenvolvimento de habilidades gerenciais do corpo burocrático (Abrucio, 1997; Matias-Pereira, 2008; Secchi, 2009; Camões, 2013). O uso destes modelos modificou a 
forma de gerenciar recursos humanos no setor público, pois houve transferência de conhecimento do setor privado para o público (Secchi, 2009).

Dentro do contexto da adoção de novas tecnologias geradas no gerencialismo as relações de trabalho sofreram alterações, dado a aprendizagem e desenvolvimento se tornarem o foco de interesse dos trabalhadores. Portanto, para Longo (2007), essas alterações propiciaram a área de gestão de pessoas alcançar nível estratégico nas organizações visto sua importância para atingir metas e objetivos. A Gestão Estratégica de Pessoas (GEP) surge dentro da cultura orientada para o bom desempenho da reforma gerencialista com o rearranjo das ações estratégicas pelas instituições para o uso eficiente de recursos organizacionais e humanos (Araújo, 2018).

A GEP se consolida como campo de estudo academicamente em meados da década de 1980 que, sumariamente, preconiza a articulação dos subsistemas de recursos humanos e destes com as diretrizes organizacionais (Lacombe \& Tonelli, 2001; Côrtes, 2016). Ela dissocia-se da antiga administração de recursos humanos, esta presa no formalismo e modelos burocráticos (Camões \& Meneses, 2016) na medida em que as práticas passam a ser pensadas de maneira integrada aos objetivos da organização para recrutar, desenvolver e reter recursos humanos que possuíssem competências estratégicas.

Em resumo, pode-se concluir que a Gestão Estratégica de Pessoas envolve o
reconhecimento das pessoas como elemento central para a organização e pode ser
resumida como: o desenvolvimento de práticas e políticas de distintos subsistemas de
Gestão de Pessoas de maneira coerente e integrada e a favor da estratégia
organizacional, visando colaborar para o alcance de seus objetivos, estimular o bom
desempenho e influenciar a cultura organizacional, considerando ainda o contexto
vivenciado (Araújo, 2018, p. 20-21).

A GEP é cercada por um cenário cada vez mais favorável à sua implantação, dado que aperfeiçoar a gestão de pessoas é um dos maiores desafios da gestão pública tornando-se uma necessidade real que acompanha obstáculos e resistências (Camões, 2013). Outro aspecto é a disseminação de que os gestores e gerentes de linha organizacional também são responsáveis pela Gestão de Pessoas, resultado advindo da defesa pela descentralização e GEP como força motriz da mudança organizacional (Terabe \& Bergue, 2014; Araújo, 2018)

A medida que a produção científica da GEP evoluiu, novas temáticas ganharam espaço na agenda de pesquisa; entre elas a análise da execução das práticas estratégicas e os resultados alcançados, logo implementação da Gestão Estratégica de Pessoas (Côrtes, 2016; Araújo, 2018). Esta temática tem sua relevância "à medida que o marco conceitual da área de gestão estratégica de pessoas se tornou mais complexo e amplo, houve um aumento na preocupação 
das organizações em promover práticas de GP que levassem à emergente de resultados organizacionais" (Camões, 2013, p.24). No entanto, ao serem realizadas pesquisas de Gestão de Pessoas na administração pública brasileira, foi constatado resultados insatisfatórios na implementação de políticas e práticas de GP (Araújo, 2018; Côrtes, 2016). A importação e uso de diferentes modelos de GP produziram mudanças no setor público, porém as transições são caracterizadas como incompletas em que "princípios de um novo modelo muitas vezes coexistiam em conflito com a cultura anteriormente vigente" (Fonseca, 2011, p. 22). Não só a cultura, mas outros aspectos institucionais e políticos também foram identificados na literatura como possíveis obstáculos a implementação. É a partir deste contexto que pesquisadores brasileiros passaram investigar a fundo os principais fatores interferentes na implementação de políticas de Gestão Estratégica de Pessoas no setor público (Fonseca, 2011; Camões, 2013; Côrtes, 2016; Araújo, 2018).

\subsection{Problematização}

O desdobrar da agenda de pesquisa resultou na classificação dos fatores interferentes em quatro dimensões: Institucionais, políticos, organizacionais e setoriais (Côrtes, 2016; Camões, 2013; Fonseca, 2013). A dimensão institucional trata de contingências externas à organização que estão fora de seu controle, mas com impacto direto nas políticas de gestão de pessoas (Fonseca, 2013; Côrtes, 2016; Araújo, 2018), a exemplo de aspectos societais como a política e economia externa ou mecanismos de controle externo tal como os órgãos de controle. Já os fatores de dimensão política "referem-se à forma como a dinâmica das relações interpessoais e intra e intergrupos influenciam a implementação da GEP abordando questões como o uso do poder, conflitos de interesses, negociação, formação de coalizões e apoio político" (Araújo, 2018, p. 24). Classificadas como de maior controle da organização, os fatores de dimensão organizacionais que tratam de questões internas seja estrutura, recursos, aspectos culturais, entre outros; e são os mais abordados pela literatura (Fonseca, 2013; Côrtes, 2016; Araújo, 2018). Por fim, os fatores de dimensão setorial “dizem respeito a variáveis restritas à própria unidade de gestão de pessoas e sob seu próprio controle que exercem influência nas práticas e políticas que desejam implementar" (Araújo, 2018, P. 27).

A pesquisa de Araújo (2018) teve o objetivo de propor relações entre os fatores intervenientes e deixa-se claro que os problemas de natureza política são solucionados de 
maneira não sistêmica, mas de ações isoladas. Além disso, a autora ressalta a imprescindibilidade de capacitação da liderança de GP em habilidades políticas. Este aspecto demonstra que o aumento do desempenho do setor de Gestão de Pessoas tem relação direta sobre o quanto ele está preparado politicamente e se insere nos principais espaços de tomada de decisão da organização. É a atuação do representante de GP e a influência que este tem no processo decisório e arranjo institucional das políticas e programas do setor que garantirá a execução fiel à estratégia organizacional, além de patrocínio da alta liderança e posição central do setor no desenho institucional (Côrtes, 2016; Araújo, 2018). É esta conjuntura que representa o fenômeno da inserção estratégica da área de GP, que trata do "nível de participação do setor nas arenas decisórias e na definição do planejamento estratégico, assim como o grau de alinhamento entre a alta administração e a área" (Araújo, 2018, p. 25). Assim sendo, a viabilidade do debate entre os formuladores das práticas de GP e atores-chaves nos processos decisórios com vista a obtenção de efetividade às políticas GP pode gerar, consequentemente, disseminação de conhecimento e apoio da cúpula administrativa (Araújo, 2018, Camões \& Meneses, 2016; Côrtes, 2016).

A literatura ressalta a importância da área de Gestão de Pessoas estar inserida nas arenas decisórias. O representante do setor - carregado de habilidades interpessoais e políticas, pode contribuir para o processo decisório estratégico (seja na formulação ou avaliação) à medida que realiza o alinhamento entre alta administração e a unidade. A área de GP pode atuar como especialista que incorpora informações necessárias para endireitar as políticas e práticas de pessoas ao ambiente organizacional (Garavan \& Costine \& Heraty, 1995).

Apresentado o contexto, faz-se necessário estudos que relatem o processo da inserção estratégica da área de Gestão de Pessoas nas arenas decisórias organizacionais no setor público. Além disso, também é essencial a análise dos elementos que circundam a inserção estratégica como os fatores que facilitam ou dificultam o acesso, assim como o impacto das habilidades políticas do líder de GP sobre o processo decisório no setor público. Por fim, pergunta-se: De que forma se dá o processo de inserção estratégica da área de GP e seus profissionais nas arenas decisórias de duas organizações públicas. 


\subsection{Objetivo geral}

Descrever o processo de inserção estratégica da área de Gestão de Pessoas e seus profissionais nas arenas decisórias de duas organizações públicas.

\subsection{Objetivos específicos}

i. Identificar os conteúdos das políticas abordadas pela área de GP nas arenas decisórias

ii. Identificar quais fatores facilitam ou dificultam a inserção estratégica da unidade de GP

iii. Identificar quais as habilidades políticas mais utilizadas pelo líder de GP para acesso às arenas decisórias

\subsection{Justificativa}

Advindo de uma linha de pesquisadores brasileiros e seus recentes estudos sobre a Gestão Estratégica de Pessoas - sobretudo na análise de fatores interferentes na implementação de políticas e práticas de GP na administração pública brasileira (Fonseca, 2013; Camões, 2013; Côrtes, 2016; Castro, 2018; Araújo, 2018), este trabalho visa complementar as produções anteriores ao tratar do fenômeno da inserção estratégica da área de gestão de pessoas e seus profissionais nas principais arenas decisórias organizacionais.

Estes estudos anteriores relataram a complexidade de se estudar o contexto organizacional do setor público (Côrtês, 2016), assim como evidenciaram o forte impacto da esfera política sobre a implementação de políticas (Côrtes, 2016; Araújo, 2018). Outro aspecto é a insuficiência teórico-empírica sobre o fenômeno da inserção estratégica na literatura nacional e estrangeira (Araújo, 2018). Porém, diferente dos periódicos anteriores, este trabalho busca transpor essa barreira ao abarcar o campo científico de políticas públicas, pois trata-se de uma literatura especializada na compreensão das decisões políticas e seus impactos na administração pública (Howlett \& Ramesh \& Perl, 2013). 
Sabendo que o fenômeno da inserção estratégica representa uma categoria dentro de fatores políticos, o campo de políticas públicas - junto com os trabalhos de GEP, propicia a compreensão das múltiplas relações entre atores da esfera pública e seus comportamentos, marcados pela não escolha técnica das decisões - mas sim pela formação de alianças para atender interesses comuns (Howlett \& Ramesh \& Perl, 2013; Rua, 2014; Forester, 1984). Esse trabalho também se preocupa em demonstrar que a temática não pode ser estudada fora de seu contexto sociocultural, pois há um padrão comportamental histórico dos atores políticos no setor público brasileiro (Costa, 2008; Lima, 1998).

Visto a garantia de acesso à recursos organizacionais, além de elevar sua reputação (Araújo, 2018) e contribuir significativamente para o alinhamento dos objetivos estratégicos e suas políticas com o gerenciamento do capital humano (Lacombe \& Chu, 2008; Ingraham \& Rubaii-Barret, 2007); compreender de que forma a área de gestão de pessoas se insere nas principais arenas decisórias contém grande relevância para uma administração pública cada vez mais colaborativa, que visa eliminar as barreiras da democracia representativa e combater as contingências políticas (Cavalcante, 2017; Araújo, 2018).

Por fim, este trabalho contribui para a academia ao retratar um fenômeno que carece de explicação. Da mesma maneira contém alta relevância para que os profissionais da gestão de pessoas reconheçam e alterem a diversidade de elementos que impactam seu trabalho e, principalmente, a possibilidade de construir uma administração pública cada vez mais eficiente. Por fim, a oportunidade de aprender sobre o contexto histórico de formação do setor público, suas reformas administrativas, e de que forma as inter-relações políticas afetam a tomada de decisão pública; é o fundamento pilar para a realização desta pesquisa e seu principal beneficiado: a sociedade brasileira. 


\section{Referencial Teórico}

Esta seção tem por objetivo apresentar o arcabouço teórico da Gestão Estratégica de Pessoas (GEP), sobretudo as características que circundam a unidade de gestão de pessoas nas organizações e sua relação com as arenas decisórias - portanto, tratando de toda esfera política associada ao processo de tomada de decisão.

Em primeiro momento, será abordado o aparato histórico, legal e institucional que corporificou a administração pública brasileira contemporânea, assim como as características de cada reforma administrativa e seu impacto na gestão de pessoas no setor público. Por conseguinte, será retratado o campo científico da Gestão Estratégica de Pessoas, seu desenvolvimento no setor privado e público, sua solidificação como política pública e os fatores interferentes na implementação de políticas de GEP. Por fim, será abordado pela recente literatura brasileira e estrangeira o fenômeno da inserção estratégica da área de GP.

Devido insuficiência de produção teórico-empírica que discorra sobre o fenômeno deste trabalho e suas particularidades, em segundo momento, será retratado o campo científico de Políticas Públicas - que se desenvolveu no Brasil paralelamente às reformas administrativas. Elementos e conceitos que circundam a inserção estratégica da área de GP como arenas decisórias, processo decisório e atores - consolidados por este campo, serão tratados; assim como outros aspectos necessários para a compreensão do principal objetivo deste trabalho. 


\subsection{O desenvolvimento da administração pública no Brasil: do modelo burocrático ao - gerencialismo (New Public Management)}

O desgaste do antigo sistema político da República Oligárquica (1889-1930), adjunto de novos conflitos de interesses entre as classes sociais dominantes e novos atores (burguesia industrial e Exército); propiciaram uma luta por ideais modernizadores na agenda pública (Costa, 2008). Além disso, a crise econômica de 1929 com impacto na redução da exportação de produtos primários brasileiros refreou a prática consequente do capital oriundo das exportações, logo; a importação de produtos industrializados (Costa, 2008). A não possibilidade da compra de produtos externos incitou o país a desenvolver seu mercado interno, bem como transferir renda no cunho de gerar emprego e consumidores. Esta conduta keynesiana do Estado ressalta não só a ascensão dos novos agentes no espaço público, mas também intensifica a pressão por uma administração pública que se moderniza ininterruptamente, sendo esta desejada no processo de formação do Estado Nacional (Costa, 2008).

O governo de Getúlio Vargas (1930-1945) foi marcado pela ruptura do antigo sistema patrimonial para a moderna administração pública burocrática weberiana (Costa, 2008); esta "baseada na centralização das decisões, na hierarquia traduzida no princípio da unidade de comando, na estrutura piramidal do poder, nas rotinas rígidas, em uma burocracia estatal formada por administradores profissionais especialmente recrutados e treinados" (Bresser, 1997, p. 9). O Estado brasileiro nesta época caracteriza-se pela concentração de poder no Executivo na finalidade de promover a modernização e - junto com a inserção dos novos atores políticos, a reforma do aparelho estatal racional e padronizado foi corporificado através de mecanismos legais e institucionais (Costa, 2008; Lima, 1998). Estes evidenciam os principais elementos da primeira reforma administrativa a medida que englobavam áreas temáticas clássicas estruturantes para as organizações públicas: administração de material, financeira e pessoal (Lima, 1998).

O Estado de Vargas é conhecido pela criação de diversas autarquias, empresas e aparatos legais como Constituição de 34, Comissão Especial do Legislativo e do Executivo (Comissão Nabuco), Conselho Federal do Serviço Público Civil e Departamento Administrativo do Serviço Público (DASP). O esforço na reforma da área de pessoal com implantação do princípio do mérito, sistema de classificação de cargos, racionalização dos métodos de trabalho e uniformidade remuneratória de cargos semelhantes; se desenvolveu em conjunto com políticas 
de intervenção econômica para equilibrar o consumo e produção do país, cortar despesas infrutíferas, fomentar a indústria e ampliar a infraestrutura (Costa, 2008).

Fica evidente o início do desenvolvimento do corpo profissional, advindo da necessidade estatal de promover uma administração progressista. Porém, o estudo de Lima (1998) ressalta que a influência do aspecto político distorceu o princípio da eficiência racionalformal, essa pregada pelo paradigma weberiano e tanto defendida pelo governo Varguista na tentativa de legitimar suas políticas. A expansão e autonomia do corpo burocrático só foi possível através dos grupos de interesses favoráveis à agenda do governo autoritário, por consequência; o Estado brasileiro não se desvinculou do patrimonialismo e das práticas clientelistas arraigadas culturalmente na máquina pública (Costa, 2008; Lima, 1998; Bresser, 1997).

Após o Estado reformista de Vargas, a literatura aborda o que ocorreu com a administração pública no período Nacional-Desenvolvimentista (1946-1964). Caraterizada pela criação de novos órgãos da administração direta e indireta, diversos relatórios e projetos de lei não aprovados, mas que geraram insumos futuros para uma nova visão; o período democrático pós estadonovista não gerou mudanças expressivas (Lima, 1998). Retrata-se também a contínua não profissionalização do servidor público e sua vulnerabilidade às relações políticas, por essa razão, Lima (1998, p. 11) afirma que "a burocracia brasileira, ao longo de todo o período aqui analisado, nunca serviu efetivamente como meio para implementar as ações políticas do governo", assim como ele reforça a não dicotomia entre política e administração (Woodrow Wilson, 1887), o impacto do clientelismo e o desempenho estatal longe do interesse público.

Para a literatura em administração pública brasileira, o governo militar (1964-1985) foi a segunda tentativa do Estado deslocar a máquina burocrática para eficiência plena e sanar os gargalos. Houve concentração de recursos pela União que possibilitou o governo retomar e examinar os projetos de lei anteriores, assim como produzir novos para aumento da produção da administração federal (Costa, 2008; Lima, 1998). O resultado deste esforço culminou com a institucionalização do Decreto-Lei $n^{\circ} 200$, de 25/02/1967. Costa (2008, p. 851) retrata a importância do instrumento legal que "se apoiava numa doutrina consistente e definia preceitos claros de organização e funcionamento da máquina administrativa". O Decreto-Lei $n^{\circ} 200$ teve por objetivo não só conceber princípios norteadores como planejamento, coordenação, descentralização, delegação de autoridade e controle à administração pública; mas também determinar as diferenças entre administração direta e indireta, fixar a estrutura do poder 
executivo, expandir o sistema de mérito e compor todo o aparato sistêmico de apoio da estrutura administrativa (Costa, 2008; Lima, 1998).

O sucesso do Decreto-Lei nº200 está pautado na adaptação do modelo burocrático contribuindo para consolidação de uma administração pública desenvolvimentista, ao ambiente político autoritário vigente naquele momento (Costa, 2008). Também, as práticas de cunho intervencionistas no objetivo de promover melhor atendimento às demandas do Estado e sociedade (bem-estar social) ressaltam a busca por eficiência e agilidade. Contudo esse enfoque resultou no crescimento da administração indireta e, principalmente, na "dicotomia entre o Estado tecnocrático e moderno das instâncias da administração indireta e o Estado burocrático, formal e defasado da administração direta" (Costa, 2008. p. 853).

Um gargalo bastante visível da reforma foi na área de pessoal. O DASP foi responsável pela atuação dos recursos humanos e, na tentativa de concretizar as demandas governamentais, formulou o novo plano de classificação de cargos fundamentado no estabelecimento de deveres e responsabilidades. Porém, sua implementação foi falha, pois o sistema de mérito permaneceu aos postos inicias de carreira, bem como o processo de seleção de novos servidores foi adulterado ao permitir o ingresso sem necessidade de concurso público (Costa, 2008; Lima, 1998, Barbosa, 1996). Lima (1998) reforça este ponto negativo da execução política militar e a herança para próxima reforma:

O fato é que a desejável e necessária profissionalização do servidor público,
novamente, não ocorreu. Não se institucionalizou a organização do tipo weberiano; a
administração indireta passou a ser utilizada como fonte de recrutamento,
prescindindo-se, em geral, do concurso público ou, na melhor das hipóteses,
recrutando através de exames específicos de habitação (Lima, 1998, p. 14).

Entre o processo de redemocratização e o governo Fernando Henrique Cardoso (19952003), a literatura aborda dois programas de reforma descritos com incrementos contínuos no decorrer das legislaturas presidenciais: desburocratização e desestatização (Costa, 2008; Lima, 1998; Bresser, 1997). Novamente visando a eficiência e eficácia na administração pública, os programas buscavam racionalizar normas organizacionais na busca por órgãos públicos ágeis que gerem benefícios para os servidores e clientes, em vista disso destacou-se o fator da priorização do usuário de serviços públicos como inédito (Costa, 2008). Outro ponto é a imposição de limites aos excessos da administração pública descentralizada, que demonstrou ser uma tentativa do governo de corrigir as práticas clientelistas dominantes (Bresser, 1997). 
As tentativas de reforma administrativa não obtiveram sucesso devido à falta de planejamento governamental e integração dos órgãos coordenadores da reforma (Costa, 2008). A Constituição de 1988 representou um avanço significativo na esfera política ao instituir princípios democráticos na garantia da cidadania, ordem social, ampliação dos mecanismos de inclusão social e outros. Porém, para a administração pública, a Carta Magna não avançou ao gerar diversos mecanismos de controle para equalizar a administração direta à indireta; portanto retirando a flexibilidade necessária da última (Costa, 2008). Além destes pontos, a literatura reforça a problemática do não planejamento governamental que resulta em práticas independentes, como a criação de mecanismos legais na tentativa de solucionar todo o histórico de disfunção burocrática (Costa, 2008; Bresser, 1997). O regime jurídico único (RJU) foi exemplo de ação não planejada que resultou no aumento do custo de pessoal (converteu celetistas em estatutários) com impacto previdenciário e firmou uma barreira "aos esforços de modernização administrativa em todos os níveis de governo (Costa, 2008, p. 859).

A década de 1990 se inicia com diversos desafios a serem enfrentados pelo Estado brasileiro. Porém, antes disso nos anos 70, se consolida o debate ao redor do mundo de que o modelo burocrático weberiano era ineficiente e uma reforma era necessária (Abrucio, 1997). A discussão se intensifica devido à crise do petróleo (1973), que estagnou o crescimento econômico mundial, acompanhado da crise fiscal em que os Estados Nacionais derrubaram o consenso social do Welfare State (Estado do Bem-estar) à medida que aumentaram os impostos sem a devolução de melhoria dos serviços públicos (Abrucio, 1997). Cavalcante (2017, p. 11) retrata a manifestação geral de que "o governo tinha se tornado sobrecarregado e insustentável do ponto de vista financeiro. Em outras palavras, o elevado nível da despesa pública gerou grandes déficits orçamentários”.

O movimento reformista deu-se início nos governos de Ronald Reagan nos Estados Unidos e Margareth Thatcher na Inglaterra. Logo, demais países desenvolvidos e emergentes priorizaram a transição de um Estado intervencionista e locomotor de políticas para "um promotor da regulação" (Cavalcante, 2017, p. 12; Costa, 2008). É incontestável a influência internacional - através do patrocínio de organizações como Fundo Monetário Internacional (FMI) e Banco Mundial, sobre os Estados Nacionais para o aumento da efetividade, eficiência e competitividade na criação e manutenção de uma administração pública inovadora centrada no cidadão (Cavalcante, 2017; Abrucio, 1997; Bresser, 1997). 
Surge a New Public Management (NPM) ou Administração Pública Gerencial (APG). Movimento pós-burocrático que estabelece uma gestão da administração pública baseada em ferramentas gerencias oriundas das organizações privadas pautadas na garantia da efetividade e competividade. Além disso, a literatura da NPM salienta o planejamento organizacional - e estratégico, através de metas e objetivos; foco nos resultados além de processos; a descentralização dos recursos humanos; a competição entre organizações públicas; e autonomia decisória para gestores (Abrucio, 1997; Costa, 2008; Camões, 2013; Cavalvante, 2017; Secchi, 2009).

No Brasil dos anos 1990 no governo Fernando Henrique, a reforma gerencial se inicia através da criação do Ministério da Administração e da Reforma do Estado (MARE) e, em caráter instrumental-legal, do Plano Diretor da Reforma do Aparelho do Estado (PDRAE). O documento traçou um diagnóstico histórico da administração pública brasileira, assim como propôs uma estratégia de mudança expondo os principais projetos (Costa,2008). Nas palavras de Bresser (1997, p. 20), o ministro responsável pela reforma:

Esta reforma terá como objetivos: a curto prazo, facilitar o ajuste fiscal,
particularmente nos estados e municípios, onde existe um claro problema de excesso
de quadros; a médio prazo, tornar mais eficiente e moderna a administração pública,
voltando-a para o atendimento aos cidadãos.

A defesa central da reforma de promover serviços públicos eficientes voltados para o cidadão com instrumentos de gestão aperfeiçoados incluiu o redesenho de estruturas mais descentralizadas, flexibilização de normas e procedimentos e; eliminar o que foi negligenciado nas reformas anteriores: os recursos humanos. Desse modo, a reforma gerencial visou "o aprofundamento das ideias de profissionalização e de permanente capacitação dos servidores públicos" (Costa, 2008, p. 864). As principais mudanças da área de pessoal: a admissão adotou critérios rígidos de mérito, estruturação das carreiras, universalização da remuneração, avaliação contínua de desempenho e treinamento sistemático (Costa, 2008).

No que tange a respeito da descentralização organizacional, a reforma autenticou a participação dos agentes privados e organizações da sociedade civil nas decisões estatais, na garantia de cumprimento da eficiência através da competição. Além disso, o Estado redefiniu seus níveis de atuação se comprometendo com a formulação, implementação e controle de políticas governamentais; descentralizou a execução de políticas exclusivas; e permitiu - para empresas privadas ou associações sem fins lucrativos, a produção de determinados bens e serviços públicos (Costa, 2008). 
Costa (2008) ao retratar o PDRAE, pontua o discurso do governo brasileiro de que: a ineficiência e rigidez da máquina pública limitavam sua capacidade de implementar políticas públicas e tudo isto era causado por um problema de governança ou seja, era necessário aumentar a capacidade de governo do Estado. Fica evidente a associação de governança com desempenho abordado pela literatura, à medida que o foco para aumentar a produtividade fez com que o setor público adotasse critérios de qualidade, estabilidade e precisão; como objetivo central para justificar o combate às práticas de patronagem e corrupção (Cavalvante, 2017).

A reiteração do discurso reformista pela defesa na melhoria da gestão - como fator necessário e único ao combate das disfunções burocráticas e cultura patrimonial; transpareceu aos especialistas da administração pública o principal problema histórico das reformas e da literatura de NPM: a incapacidade de reconhecimento e tratamento das influências políticas sobre a burocracia e poder da burocracia no Estado. Essa lacuna é bem retratada por Martins (1997) que descreve a má interpretação da literatura de weber por autores que difundiram a promessa de felicidade organizacional no gerencialismo. Contudo ele afirma que a "tradição organizacional pós-burocrática se baseou no falso pressuposto de que o problema da burocracia era exclusivamente organizacional” (Martins, 1997, p. 51).

A reforma administrativa de 1990 falhou ao não contemplar o elemento político em sua formulação e implementação, pois não gerou mecanismos suficientes de coordenação política (Costa, 2008). Argumenta-se também que o excesso de preocupação com o ajuste fiscal nas contas públicas (alicerce da política neoliberal) e, consequente pressão para diminuir a máquina; justificam a incapacidade de o Poder Executivo concretizar sua política de governo através da burocracia (Pereira, 2008). Além do Brasil não consolidar sua burocracia pública, a literatura evidência as contraditoriedades político-administrativas e a continua existência da cultura patrimonial exteriorizada pelo clientelismo e corporativismo; portanto, a falsa dicotomia entre administração e política advém do caráter incremental e adaptativo do comportamento dos atores entre as reformas da administração pública brasileira (Costa, 2008; Martins, 1997; Pereira, 2008).

O insucesso e frustação das grandes reformas estatais, embora estas baseadas em ideias e critérios técnicos, dar-se devido aos contextos em que estes estão inseridos: "sistemas políticos com configurações próprias, bem definidas, com padrões regulares de ação e decisão" (Lima, 1998, p. 21). Explora-se o fato de que as estruturas organizacionais vigentes no setor público refletem os interesses dos atores que obtiveram vitória nas arenas políticas, assim como 
o constante argumento de combate ao corporativismo fundamenta aqueles que desejam equilibrar ou alterar as estruturas de poder (Lima, 1998).

Antes de encerrar esta seção, cabe afirmar a tentativa de ampla análise da produção sobre administração pública brasileira para o estudo, assim como as dificuldades para tal devido fatores discutidos por Costa (2008, p. 855) em que "o processo de reforma está estreitamente ligado ao contexto político, social e cultural do país, o que significa que não se pode enfatizar somente os aspectos legais e técnicos". O estudo de Cavalvante (2017) buscou retratar o progresso da literatura sobre os princípios e diretrizes de gestão que circundam o setor público após as reformas da NPM. O trabalho trata de possíveis evidências para um pós-gerencialismo, ou seja, ruptura para um novo modelo de administração pública. Porém, o que ficou evidente foi o aspecto incremental para a formulação de soluções em vez de um novo desenho. Cavalcante (2017) destaca que o Pós-NPM - atual movimento na administração - não descarta a inserção de ferramentas da gestão privada no setor público e os princípios de eficiência e responsividade originários do gerencialismo, mas que insere a "autoridade burocrática do Estado na condução de políticas públicas" (Cavalvante, 2017, p. 25).

O autor ainda ressalta a importância da garantia dos espaços de discussão e debate na esfera pública pois, no cunho da tentativa de enfrentar os antigos problemas da máquina, o Estado deve atuar com "maior priorização da ampliação da cooperação nos processos decisórios, surge uma segunda proposta alternativa que circunda a ideia de governança" (Cavalcante, 2017, p. 25). O argumento recai sobre a necessidade de reconhecer e ampliar os relacionamentos dos diversos atores na administração pública no objetivo de vencer os déficits da democracia representativa (Cavalcante, 2017, p. 25).

Assim, o incremento do controle e da accountability ganha força na construção de
políticas públicas por meio de mecanismos de participação democráticos e
deliberativos que, por conseguinte, impactam no aperfeiçoamento da gestão e da
oferta de serviços públicos. Com essa diretriz, a perspectiva de governança tem como
finalidade tornar o governo melhor informado, mais flexível e menos exclusivo

De forma geral, compreender o modo como a administração pública brasileira foi constituída e alterada pelas suas reformas possibilita interpretar o complexo contexto que circunda a máquina pública. Sobretudo, o ambiente de competição política que impacta as estruturas de poder e revelam as influências políticas, sociais e culturais sobre todo tipo de tomada de decisão no Estado. Decisões governamentais baseadas em práticas clientelistas não priorizando o caráter técnico das decisões, pois qualquer progresso do profissionalismo público 
deveu-se à grupos de interesse que introduziram com sucesso o tema na agenda pública. Sucesso este garantido a partir do incremento e adaptação comportamental dos atores políticos.

Estas características refletem a forma da introdução e desenvolvimento da gestão de pessoas no setor público e, por conseguinte, retratam aspectos necessários para o entendimento do fenômeno da inserção estratégica - à medida que o conceito aborda o grau de participação do setor de GP nas arenas decisórias (Araújo, 2018). Com esse fito, para além do contexto histórico do Estado, a próxima seção abordará o que foi desenvolvido no campo científico da gestão estratégica de pessoas, inicialmente se dedicando a estudos do setor privado até a recente linha de pesquisa sobre a gestão de pessoas no setor público brasileiro e os trabalhos acerca do fenômeno em tela.

\subsection{Gestão Estratégica de Pessoas no Setor Público}

A globalização propiciou grande difusão de conhecimento possibilitando sociedades e culturas serem transformadas, bem como organizações reconhecerem a relevância de seus recursos humanos; conforme expõe Longo (2007, p. 23): “os grandes objetivos de qualquer projeto coletivo contemporâneo parecem depender em boa medida da correta provisão, desenvolvimento e utilização do capital humano". Devido esta retomada de enfoque sobre pessoas, diversos periódicos ressaltaram a importância de a gestão de pessoas estar aliada à valores e exercícios estratégicos (Longo, 2007). A partir desta produção surge umas das abordagens teóricas para o estudo de Gestão de Pessoas (GP). Classificada como estratégica, esta abordagem propicia a análise e entendimento das pessoas como instrumentos para ganho de vantagem competitiva; alinhar as práticas e políticas interna e externamente, à medida que as relacionam com a estratégia de negócios; desenvolver proatividade na gestão; e etc. (Lacombe \& Chu, 2008).

A abordagem estratégica se desenvolve conforme a ruptura da antiga perspectiva sobre recursos humanos. Longo (2007) retrata a transição da administração de pessoal - caracterizada como atividade de suporte para áreas consideradas geradoras de valor como produção, vendas e finanças; para gestão dos recursos humanos. Esta passagem manifestou-se através da elevação das "unidades especializadas de recursos humanos na estrutura de autoridade formal das organizações" (Longo, 2007, p. 49), conforme gerentes romperam com o formalismo extremo 
do modelo anterior resultando, portanto, no surgimento do movimento da Gestão Estratégica de Pessoas (GEP) (Camões \& Meneses, 2016).

A literatura conceitua a GEP como a evolução de políticas e práticas dos múltiplos subsistemas de gestão de pessoas em conformidade com a estratégia organizacional para o alcance de objetivos resultando, consequentemente, em mudanças na geração de bom desempenho e influencia na cultura organizacional (Buyens \& De Vos, 2001; Ingraham \& Rubaii-Barret, 2007; Araújo, 2018; Camões, 2013; Camões \& Meneses, 2016). Ingraham \& Rubaii-Barret (2007) consideram a gestão estratégica de pessoas como primordial para qualquer organização, por construir diretrizes para todas as atividades referentes a pessoal como seleção, remuneração e distribuição de benefícios segundo desempenho; porém, se houver mal gerenciamento, pode resultar na criação de ineficiências.

A GEP - como já abordado, além de propiciar o pensamento de práticas integradas aos objetivos organizacionais para o desenvolvimento de recursos humanos, disseminou o argumento de que a Gestão de Pessoas (GP) também é responsabilidade de todos os gestores da organização descentralizando, portanto, as atribuições da área de recursos humanos para os gerentes de linha (Araújo, 2018). Ocupando posição cada vez mais central nas decisões tomadas em diferentes níveis organizacionais, a GEP relembra os principais tomadores de decisão que o investimento em pessoas é uma prioridade chave da organização (Sheehan, 2015).

Côrtes (2016) retrata o desenvolvimento da gestão estratégica de pessoas como campo científico, à medida que expõe os principais temas de investigação dos pesquisadores (apud Lengnick-Hall et al., 2009; apud Marler \& Fisher, 2013) como: (i) estudos contingenciais para unir práticas e políticas de gestão de pessoas a elementos estratégicos; (ii) investigação da transição entre administração de recursos humanos para gestão de pessoas com defesa da última, devido suas contribuições; (iii) "expansão do escopo das atividades da GEP além das fronteiras organizacionais convencionais" (Côrtes, 2016, p. 29); (iv) construção de estruturas e componentes dos subsistemas de gestão de pessoas; (v) "importância da implementação e execução efetivas das políticas e práticas de GP de forma a assegurar o cumprimento do intento estratégico (Côrtes, 2016, p. 29); (vi) mensuração dos resultados da GEP; e (vii) avaliação de questões metodológicas. A seguir segue a síntese dos sete temas e suas ideias principais na Tabela 1. 
Tabela 1. Sete principais temas da GEP

\begin{tabular}{|c|c|}
\hline Temática & Ideia central \\
\hline $\begin{array}{l}\text { Explicação das perspectivas de } \\
\text { contingência e ajuste }\end{array}$ & $\begin{array}{l}\text { Conjuntos particulares de práticas de GP tendem a ter } \\
\text { melhor desempenho se combinados com objetivos, } \\
\text { condições e interesses estratégicos específicos }\end{array}$ \\
\hline $\begin{array}{l}\text { Mudança de foco da administração } \\
\text { de recursos humanos para a criação } \\
\text { de contribuições estratégicas }\end{array}$ & $\begin{array}{l}\text { Transição da visão de administração de recursos } \\
\text { humanos tradicional para aquela baseada nas } \\
\text { contribuições do capital humano, capacidades } \\
\text { estratégicas e desempenho organizacional competitivo, } \\
\text { além da mudança de papel do profissional de GP }\end{array}$ \\
\hline $\begin{array}{l}\text { Elaboração de componentes e } \\
\text { estruturas do sistema de GP }\end{array}$ & $\begin{array}{c}\text { Políticas e práticas de GP são processos complexos e } \\
\text { interdependentes que não deveriam ser considerados } \\
\text { independentemente, mas sim examinados como } \\
\text { subsistemas ou pacotes }\end{array}$ \\
\hline Expansão do escopo da GEP & $\begin{array}{l}\text { Mudança do foco das ações internas à organização para } \\
\text { aquelas presentes em unidades de negócio, grupos de } \\
\text { interesse, cadeia de valor e contexto internacional }\end{array}$ \\
\hline Implementação e execução da GEP & $\begin{array}{l}\text { Preocupação com a habilidade de uma empresa para } \\
\text { realmente atingir as práticas de GEP almejadas e os } \\
\text { consequentes resultados estratégicos esperados }\end{array}$ \\
\hline Mensuração dos resultados da GEP & $\begin{array}{c}\text { Determinação de medidas válidas e representativas das } \\
\text { atividades de GEP, acerca de questões como } \\
\text { desempenho e resultados }\end{array}$ \\
\hline $\begin{array}{l}\text { Avaliação de questões } \\
\text { metodológicas }\end{array}$ & $\begin{array}{l}\text { Importantes preocupações metodológicas decorrentes do } \\
\text { amadurecimento do campo e do estabelecimento mais } \\
\text { completo de quadros conceituais e suposiçôes teóricas }\end{array}$ \\
\hline
\end{tabular}

Fonte: Retirado de Côrtes (2016) segundo apud Lengnick-Hall et al. (2009).

A literatura sobre gestão estratégica de pessoas não se desenvolveu somente pela análise de organizações privadas. No que tange ao seu desenvolvimento no setor público, o movimento gerencialista propiciou a inserção da GEP e seus modelos como instrumentos adequados para cumprimento das metas reformistas do governo (Fonseca, 2011). A Política Nacional de Desenvolvimento de Pessoal (PNDP), outorgada pelo Decreto 5.707/06, concedeu à gestão de pessoas o status de política pública elevando a gestão do capital humano como condição estratégica. Isto foi possível devido à alta administração pública inserir a gestão de pessoas como um dos fatores efetivos em suas decisões, pois os debates à cerca do tema abarcaram o argumento da defesa à melhoria e eficácia dos serviços públicos (Terabe \& Bergue, 2014; Moura \& Souza, 2016).

Elementos advindos da literatura - análise da gestão estratégica de pessoas no setor privado, como a função de Recursos Humanos estar próxima à alta administração, responsabilização da GP a todos os gestores, e admissão de pessoas como fator primário das 
organizações (Terabe \& Bergue, 2014); não diferem das características da GEP no setor público. Devido maior complexidade, a diferença se encontra ao abordar a importância de posicionar agentes públicos, tanto servidores como atores políticos, no centro da organização (Terabe \& Begue, 2014).

Outra característica da GEP na administração pública é o impacto da perspectiva estratégica sobre a ótica da organização como "um sistema social em permanente interação com seu contexto" (Terabe \& Bergue, 2014, p. 21), pois possibilita reconhecer que o capital humano pode se desenvolver continuamente - independente dos limites organizacionais, gerando; portanto, agregação de valor a toda máquina pública pelos servidores.

Porém, mesmo com avanços da gestão estratégica no setor público, há discrepância entre os discursos e as práticas organizacionais sobre a GEP; estas por vezes são contraditórias (Moura \& Souza, 2016). As ações de gestão estratégica de pessoas no Brasil ocorreram com atraso, mesmo que a literatura já evidenciava a relevância da perspectiva estratégica; devido ao setor de GP prosseguir com suas atividades normativas e poucas atribuições estratégicas (Moura \& Souza, 2016).

Moura \& Souza (2016) também retratam o comportamento contrário ao pensamento estratégico dos gerentes responsáveis pela área de GP, pois - ainda que estes afirmam a necessidade de ações não operacionais, não conseguem discernir o estratégico do operacional. Além da contradição, ficou evidente a adaptação ou importação de modelos e metodologias de gestão estrangeiras pelas áreas de GP com defesa ao discurso da modernidade; "contudo, o que se observa é uma desarticulação entre esses modelos e o não alinhamento desses à estratégica da organização" (Moura \& Souza, 2016, p. 580).

Outra pesquisa relatou algumas distorções como a ausência de um planejamento da força de trabalho e estrutura de incentivos, que dificultam na concretização de uma política de gestão de pessoas efetiva na administração pública (Moura \& Souza, 2016; Marconi, 2010). Ou seja, as ferramentas de GEP têm sido aplicadas erroneamente. Também fica evidente, através dos resultados da OCDE (apud, 2010) apresentados por Moura \& Souza (2016), que os processos de formulação e decisão das políticas de GP são impactados não só por fatores estruturais, mas políticos. O relatório "deixa claro que o planejamento estratégico da força de trabalho decorre ainda de situações emergenciais, pedidos corporativistas e demanda dos órgãos", ao invés de ser um produto da perspectiva estratégica no cumprimento dos objetivos organizacionais (Moura \& Souza, 2016, p. 582). 
De forma geral, é incontestável o impacto que o ambiente da administração pública exerce sobre os subsistemas da gestão de pessoas. A implementação das políticas de GEP contém disparidades aos objetivos que foram previamente formulados - como exemplifica Camões (2013) em seu estudo sobre a PNDP ao retratar que aspectos como a descontinuidade dos atores envolvidos inicialmente na política, a fragmentação e não cooperação dos órgãos responsáveis; demonstram a "importância de considerar aspectos inerentes ao processo político que, conforme apresentados nesse estudo, estão no cerne da questão quando se trata de administração pública" (Camões, 2013, p. 176).

É por meio do estudo da inserção estratégica da área de GP que se pode compreender não só a dimensão política sobre a implementação da GEP, mas também a forma como o setor se comporta frente às descontinuidades políticas e busca apoio da alta administração na garantia de obter recursos para a efetivação das políticas da área (Araújo, 2018). Contudo, para que o estudo do fenômeno fosse possível, uma linha de pesquisas anteriores sobre a implementação e execução das políticas de gestão estratégica de pessoas no setor público além de revelarem os diversos impedimentos na efetuação das políticas, ressaltam também a necessidade das áreas de GP se inserirem nas principais arenas decisórias organizacionais (Araújo, 2018; Camões \& Meneses, 2016; Côrtes, 2016; Camões, 2013). Na próxima sessão, serão abordadas as descobertas desta recente e relevante agenda de pesquisa.

\subsubsection{Fatores interferentes na implementação da GEP nas organizações públicas}

A Gestão de Pessoas tem visível relevância no ambiente público, à medida que organizações necessitam contratar, treinar e reter seus funcionários, assim como desenvolver políticas coerentes de pessoal que abarquem todas estas peculiaridades organizacionais (Côrtes, 2016). Porém, devido às particularidades que circundam o setor público na produção para o atendimento ao interesse público; a complexidade é consequência inerente do processo políticoadministrativo, assim como produz entraves para a ascensão do setor de GP ao nível de parceiro estratégico das organizações públicas (Côrtes, 2016).

A partir do diagnóstico sobre as características que circundam a implementação da gestão estratégica de pessoas; Côrtes (2016) apresenta uma busca bibliográfica em que identifica e classifica, de acordo com a categorização e adaptação de Fonseca (apud, 2013) e 
Camões (2013), quatro dimensões - ou fatores, interferentes na implementação da GEP sintetizados na Tabela 2.

Tabela 2. Síntese das categorias propostas para os fatores interferentes

\begin{tabular}{|c|c|c|}
\hline Fatores & Categorias & Definições \\
\hline \multirow{3}{*}{ Institucionais } & Aspectos societais & $\begin{array}{l}\text { Conjuntura econômica, macro política e } \\
\text { social externa }\end{array}$ \\
\hline & $\begin{array}{l}\text { Legislação e normas } \\
\text { externas }\end{array}$ & $\begin{array}{l}\text { Coerência, constância, unidade e } \\
\text { completude do conjunto de leis, decretos e } \\
\text { normas produzidas fora da organização que } \\
\text { disciplinam assuntos relativos à GP }\end{array}$ \\
\hline & $\begin{array}{l}\text { Mecanismos de controle } \\
\text { externo }\end{array}$ & $\begin{array}{l}\text { Atividades de verificação e controle do } \\
\text { cumprimento das regras contidas no } \\
\text { arcabouço legal e jurídico de GP }\end{array}$ \\
\hline \multirow{5}{*}{ Políticos } & $\begin{array}{l}\text { Configuração política da } \\
\text { organização }\end{array}$ & $\begin{array}{l}\text { Padrão de uso das influências e de critérios } \\
\text { políticos na formação da agenda da alta } \\
\text { cúpula }\end{array}$ \\
\hline & $\begin{array}{l}\text { Apoio da alta } \\
\text { administração }\end{array}$ & $\begin{array}{l}\text { Nível de suporte decisório e fornecimento de } \\
\text { recursos para a consecução das atividades de } \\
\text { GP }\end{array}$ \\
\hline & $\begin{array}{l}\text { Descontinuidade } \\
\text { administrativa }\end{array}$ & $\begin{array}{l}\text { Instabilidade das coalizões, mandatos } \\
\text { políticos curtos e rotatividade de gestores }\end{array}$ \\
\hline & $\begin{array}{l}\text { Habilidade política da } \\
\text { liderança de GP }\end{array}$ & $\begin{array}{l}\text { Capacidade do dirigente de GP de } \\
\text { influenciar atores e grupos de interesse }\end{array}$ \\
\hline & $\begin{array}{l}\text { Inserção estratégica da } \\
\text { unidade de GP }\end{array}$ & $\begin{array}{l}\text { Presença da unidade de GP nas arenas } \\
\text { decisórias, com liberdade para discutir, } \\
\text { formular, monitorar e revisar propostas para } \\
\text { a área }\end{array}$ \\
\hline \multirow{7}{*}{ Organizacionais } & Aspectos culturais & $\begin{array}{l}\text { Valores predominantes e grau de resistência } \\
\text { à mudança }\end{array}$ \\
\hline & Recursos organizacionais & $\begin{array}{l}\text { Quantidade e qualidade dos recursos } \\
\text { humanos, tecnológicos e financeiros } \\
\text { controlados pela organização }\end{array}$ \\
\hline & Estrutura organizacional & $\begin{array}{l}\text { Configuração da estrutura organizacional, } \\
\text { envolvendo os níveis de hierarquização e } \\
\text { departamentalização e a presença de } \\
\text { mecanismos de governança }\end{array}$ \\
\hline & $\begin{array}{c}\text { Engajamento de gestores e } \\
\text { servidores }\end{array}$ & $\begin{array}{l}\text { Envolvimento e participação dos gerentes de } \\
\text { linha e servidores nas políticas e práticas de } \\
\text { GP }\end{array}$ \\
\hline & $\begin{array}{l}\text { Comunicação } \\
\text { institucional }\end{array}$ & $\begin{array}{l}\text { Nível de transparência na disponibilização } \\
\text { de informações ao público externo e interno }\end{array}$ \\
\hline & Normas internas & $\begin{array}{l}\text { Arcabouço normativo sobre GP produzido } \\
\text { no âmbito interno das organizações }\end{array}$ \\
\hline & $\begin{array}{c}\text { Planejamento estratégico } \\
\text { organizacional }\end{array}$ & $\begin{array}{l}\text { Processo intencional e objetivo de } \\
\text { planejamento que culmina em um plano } \\
\text { estratégico organizacional }\end{array}$ \\
\hline
\end{tabular}




\begin{tabular}{|c|c|c|}
\hline \multirow{7}{*}{ Setoriais } & $\begin{array}{c}\text { Integração estratégica de } \\
\text { GP }\end{array}$ & $\begin{array}{l}\text { Interdependência entre os subsistemas de } \\
\text { GP e coerência destes com a estratégia } \\
\text { organizacional }\end{array}$ \\
\hline & $\begin{array}{l}\text { Reputação da unidade de } \\
\text { GP }\end{array}$ & $\begin{array}{l}\text { Percepção de servidores, gestores e alta } \\
\text { administração sobre a efetividade da } \\
\text { unidade de GP no atendimento às suas } \\
\text { expectativas }\end{array}$ \\
\hline & $\begin{array}{l}\text { Recursos da unidade de } \\
\text { GP }\end{array}$ & $\begin{array}{l}\text { Quantidade e qualidade dos recursos } \\
\text { humanos e materiais controlados pela } \\
\text { unidade de GP }\end{array}$ \\
\hline & $\begin{array}{l}\text { Autonomia da unidade de } \\
\text { GP }\end{array}$ & $\begin{array}{l}\text { Liberdade de ação da unidade de GP para } \\
\text { condução de suas atividades }\end{array}$ \\
\hline & $\begin{array}{l}\text { Estrutura da unidade de } \\
\text { GP }\end{array}$ & $\begin{array}{l}\text { Configuração da estrutura da unidade de GP, } \\
\text { envolvendo sua posição na estrutura } \\
\text { organizacional e seus níveis internos de } \\
\text { hierarquização e departamentalização }\end{array}$ \\
\hline & $\begin{array}{l}\text { Metodologia de } \\
\text { implementação }\end{array}$ & $\begin{array}{l}\text { Grau de adequação e de complexidade do } \\
\text { modelo estratégico de GP adotado }\end{array}$ \\
\hline & $\begin{array}{l}\text { Coexistência do papel } \\
\text { funcional de GP }\end{array}$ & $\begin{array}{l}\text { Proporção da divisão de tempo e esforço da } \\
\text { unidade de GP dirigidos para suas atividades } \\
\text { funcionais e estratégicas }\end{array}$ \\
\hline
\end{tabular}

Fonte: Côrtes (2016), p. 103-104.

O fator - ou dimensão, institucional está relacionado aos aspectos externos a organização, fora de seu controle; porém afetam o processo político-administrativo das políticas de GP, estruturação ou gestão das atividades finalísticas, portanto, "podendo gerar dificuldades em relação à flexibilidade e às adaptações necessárias para mudanças internas" (Côrtes, 2016, p. 38; Araújo, 2018). Aspectos societais, legislação e normas externas e mecanismos de controle externos são categorias desta dimensão.

Configuração política da organização, apoio da alta administração, habilidade política da liderança de GP, descontinuidade administrativa e a inserção estratégica da área de GP são categorias da dimensão política; esta que aborda de que forma as relações de poder, barganha, negociação, conflito de interesses, coalizões e apoio político - advindas das dinâmicas de relações interpessoais e intra e intergrupos, impactam na implementação da GEP (Côrtes, 2016; Araújo, 2018). Côrtes (2016) também destaca a sobreposição de critérios técnicos por políticos nas escolhas referentes à GP, divergência das agendas dos atores políticos com os gestores da organização (Ingraham \& Rubaii-Barrett, 2007), mudanças de prioridade nas atividades de GP por causa do ambiente político.

As categorias do fator organizacional são: aspectos culturais, recursos organizacionais, estrutura organizacional, engajamento de gestores e servidores, comunicação institucional, normas internas e planejamento estratégico organizacional. Está dimensão representa as 
questões internas, logo engloba as categorias de maior controle organizacional e recorrente tratamento destas pela literatura (Araújo, 2018, apud Fonseca, 2013).

Por fim, a dimensão setorial aborda "as variáveis restritas à própria unidade de GP e sob seu próprio controle que exercem influência nas práticas e políticas que desejam implementar" (Araújo, 2018, p. 27). Fazem parte deste fator categorias como: integração estratégica de GP; reputação, recursos, autonomia e estrutura - todos da unidade de GP; metodologia de implementação; e coexistência do papel funcional de GP.

No decorrer do estudo ao analisar as relações entre as dimensões, Côrtes (2016) verifica o vínculo entre os fatores intervenientes e o processo político-administrativo das políticas de GEP. Segundo o autor é possível visualizar "uma cadeia de relações, em que o ambiente institucional influencia precipuamente o político, em especial quanto à formação da agenda e condicionamento do processo decisório" (Côrtes, 2016, p. 109). A partir do âmbito político das decisões, estas resultam em ações oficiais que modelarão as práticas organizacionais e, por conseguinte, as setoriais (Côrtes, 2016). Outro ponto é que os recursos e a estrutura pertencentes à unidade de GP são condicionados ao contexto organizacional (Côrtes, 2016). Por fim, o autor aborda a possibilidade de retroalimentação na cadeia de relações em que a reputação da unidade de GP influi nas decisões que atinge o setor, podendo ou não serem alteradas. A Figura 1 simplifica a cadeia de relações.

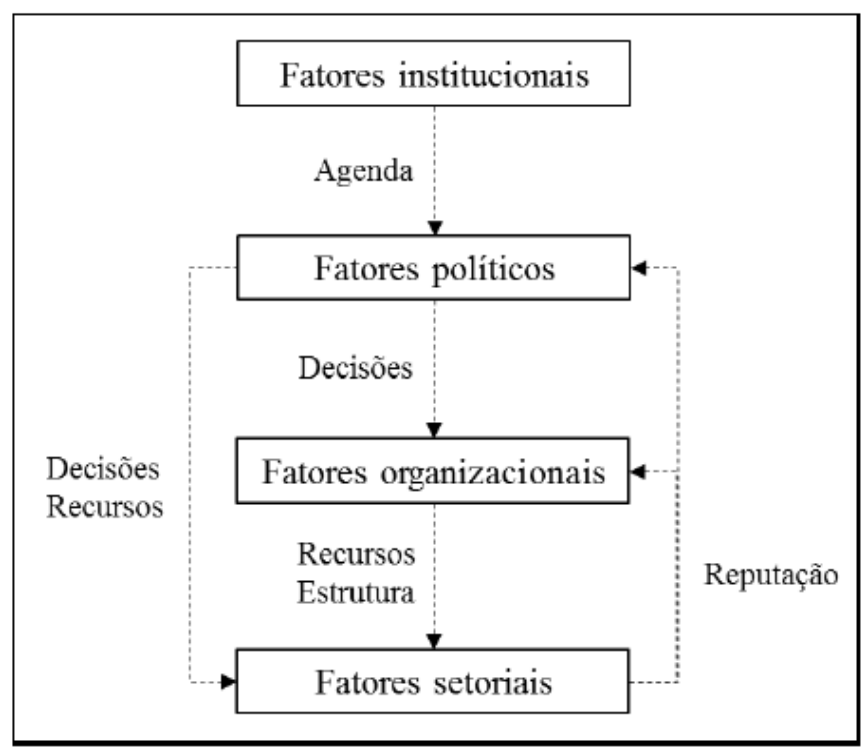

Figura 1. Modelo simplificado de cadeia de relações entre fatores

Nota. Fonte: Côrtes (2016) 
Além do modelo de Côrtes (2016), uma pesquisa sobre a gestão de desempenho no executivo federal - que buscou identificar iniciativas para o enfrentamento aos fatores intervenientes na implementação, por Araújo (2018); sucedeu na proposição de um modelo que representasse as relações entre as categorias, seus impactos e efeitos de uma sobre a outra. Segundo a autora, categorias como apoio da alta administração, engajamento de gestores e servidores e aspectos culturais são os que mais recebem impactos das demais categorias. Em vista disso, Araújo (2018) ressalta a complexidade existente na administração pública devido as diversas relações entre categorias. A seguir segue o modelo lógico na Figura 2 em que unidade de GP, mesmo se optar pela solução de determinada interferência, deverá conjecturar outras limitações.

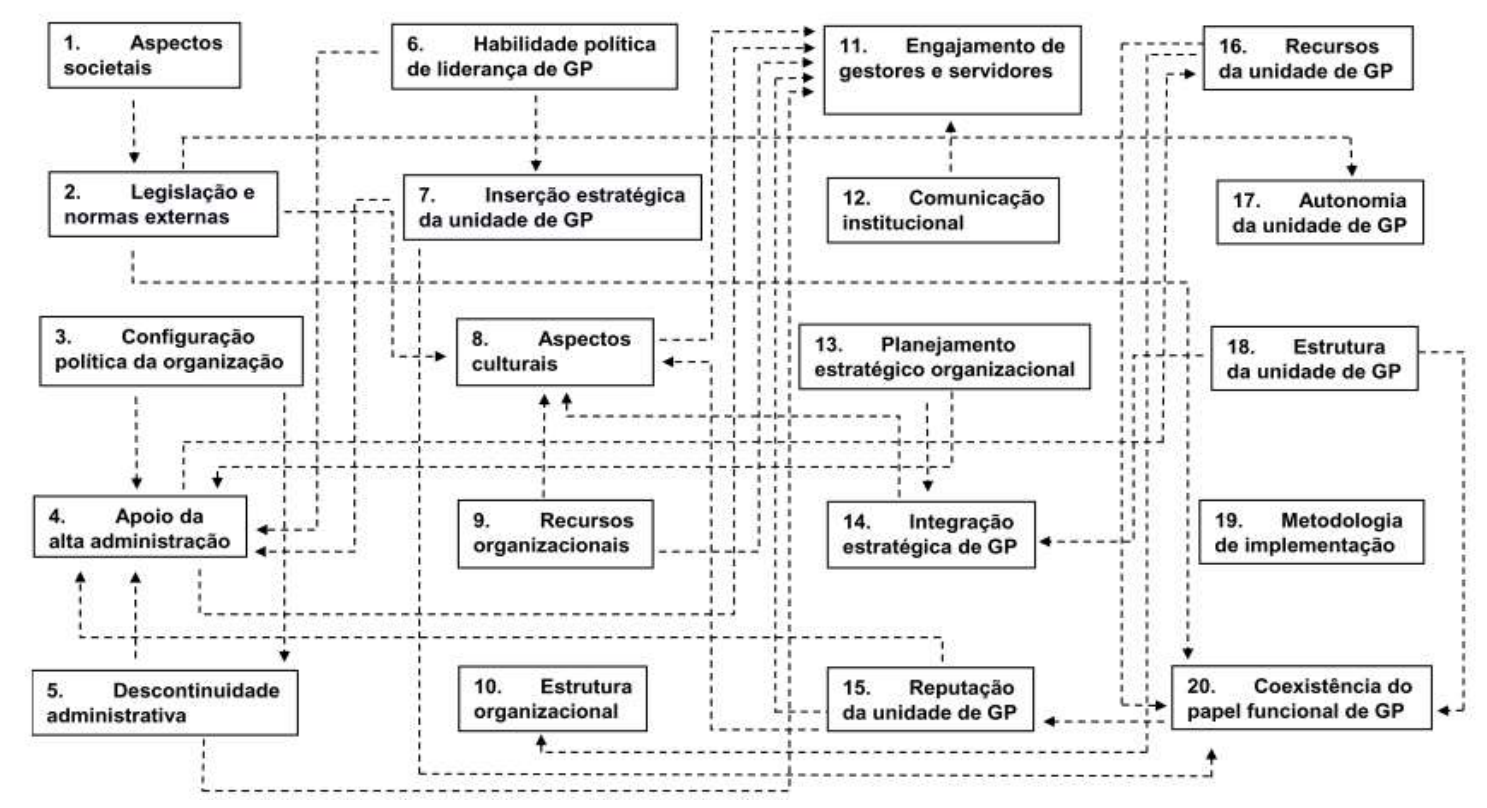

Figura 2. Modelo lógico das dificuldades enfrentadas.

Fonte: Extraído de Araújo (2018)

Sobre o modelo, é necessário ressaltar a categoria da inserção estratégica da unidade de Gestão de Pessoas, por ser objeto deste estudo. Definido como a "presença das unidades de GP nas arenas decisórias, com liberdade para discutir, formular, monitorar e revisar propostas para área" (Côrtes, 2016, p. 75); esta sofre influência da habilidade política da liderança de GP e, consequentemente, ocasiona o apoio da alta administração para que o setor tenha acesso à recursos próprios e eleve sua reputação. O modelo de Araújo (2018) se relaciona com a descoberta de Côrtes (2016) ao ressaltarem a forte presença do fator político como chave para 
implementação das políticas de GEP - devido o apoio da alta administração ser a categoria com mais variáveis influentes, os autores acentuam a necessidade do aumento de investimento das habilidades políticas da liderança de GP para consecutiva inserção estratégica da área de GP (Côrtes, 2016; Araújo, 2018).

A inserção estratégica e sua relação com a coexistência do papel funcional de GP, evidencia que o nível de acesso da unidade às arenas decisórias reflete diretamente nas atribuições da unidade - portanto, possibilitando modificar e delimitar o papel funcional do setor (Araújo, 2018). Outro modelo lógico - no cunho de relacionar os fatores interferentes com iniciativas organizacionais implementadas para solução, foi desenvolvido por Araújo (2018). Este constructo reafirma de que forma as dimensões política, setorial e institucional instigam às alterações organizacionais, ao invés deste último refletir sobre as demais (Araújo, 2018). Sobre a inserção estratégica da unidade de GP, a solução para elevar o nível de participação foi a criação de uma unidade de governança de pessoas central - que resultaria na instigação do desenvolvimento das habilidades políticas da liderança de GP (Araújo, 2018). A seguir segue o modelo representado na figura 3.

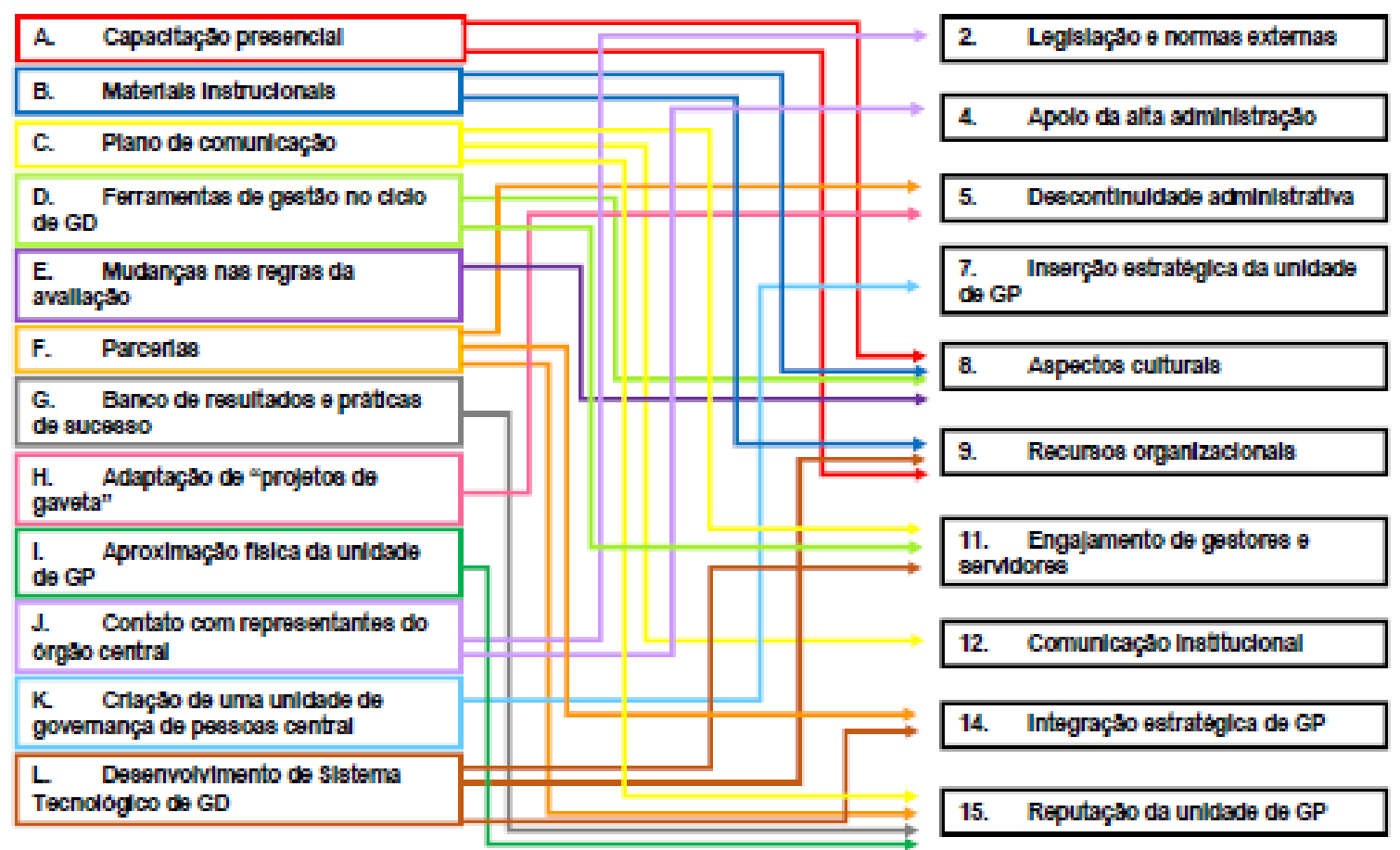

Figura 3. Modelo lógico que relaciona as iniciativas implementadas e as dificuldades enfrentadas.

Fonte: Extraído de Araújo (2018) 
Corroborando para continuidade da linha de pesquisa sobre GEP, um novo estudo a respeito das iniciativas adotadas por organizações públicas no cunho de facilitar a implementação de políticas e práticas estratégicas - nas dimensões estratégica, estrutural e cultural; contribuiu para a identificação de 21 fatores organizacionais intervenientes (Castro, 2018). O estudo ressaltou que, dentre os distintos fatores representados na Tabela 3, cinco obtiveram maior relevância após a aplicação da Análise de Redes Sociais (ARS): Papel da Unidade de GP na implementação de estratégias organizacionais, Grau de participação dos funcionários nos processos de mudança, Grau de flexibilidade da cultura, Natureza dos processos de trabalho e Comunicação interna. A ARS possibilitou a interpretação de padrões de conexão entre diferentes atores integrantes de uma rede, portanto, avaliando-os sistematicamente o relacionamento entre eles (Castro, 2018).

Tabela 3. Fatores estratégicos, estruturais e culturais interferentes na implementação.

\begin{tabular}{|c|c|}
\hline Fator & Categorias \\
\hline \multirow{4}{*}{ Estratégico } & Existência de planejamento estratégico organizacional \\
\hline & Papel da unidade de GP na implementação das estratégias organizacionais \\
\hline & Existência de um plano estratégico da área de GP \\
\hline & Unidade de GP focada em atividades operacionais \\
\hline \multirow{11}{*}{ Estrutural } & Comunicação interna \\
\hline & Natureza dos processos de trabalho \\
\hline & Instabilidade estrutural \\
\hline & Desenho de cargos \\
\hline & Centralização do processo decisório \\
\hline & Posição da unidade de GP na hierarquia da organização \\
\hline & Normas internas \\
\hline & Estrutura informal \\
\hline & Número de níveis hierárquicos na organização \\
\hline & Quantidade de servidores \\
\hline & Rigidez estrutural \\
\hline \multirow{6}{*}{ Cultural } & Grau de flexibilidade da cultura \\
\hline & Capacitação dos servidores \\
\hline & Grau de participação dos funcionários nos processos de mudança \\
\hline & Grau de conhecimento da cultura \\
\hline & Comprometimento \\
\hline & Recompensas financeiras e motivacionais \\
\hline
\end{tabular}

Fonte: Adaptado de Castro (2018)

Sobre a análise da dimensão estratégica no estudo, particularmente o "Papel da unidade de GP na implementação das estratégias organizacionais”; Castro (2018) ressalta o vínculo desta categoria com as diversas iniciativas adotadas pelo setor público representadas na Tabela 
4. Estas soluções foram definidas através da análise das propostas existentes na literatura, assim como os insumos advindos das entrevistas nas organizações pesquisadas. O autor reafirma as características teóricas da abordagem estratégica em gestão de pessoas, à medida que atesta a categoria como elemento central para a implementação - pois sobre esta predominam "as influencias estabelecidas por iniciativas estruturais e estratégicas” (Castro, 2018, p. 180).

“O Papel da unidade de GP na implementação das estratégicas organizacionais" contém possível relação com a inserção estratégica, devido à conexão entre os estudos apresentados (Côrtes, 2016; Araújo, 2018; Castro, 2018). No modelo lógico das relações de Araújo (2018), a categoria "Coexistência do papel funcional de GP" de dimensão setorial alega a divisão de atenção equivalente do setor para os papéis funcionais e estratégicos, contudo; a partir da inserção estratégica que se definirá o nível de acesso às arenas decisórias e - consequente, definição destas atribuições. Por fim, o papel da unidade de GP frente às implementações será estabelecido via acesso e participação nas arenas.

\section{Tabela 4. Iniciativas consolidadas}

\begin{tabular}{|l|l|}
\hline Categoria & Iniciativa \\
\hline \multirow{4}{*}{ Estratégica } & Realizar parcerias estratégicas \\
\cline { 2 - 3 } & Adotar um plano estratégico da unidade de GP \\
\cline { 2 - 3 } & $\begin{array}{l}\text { Assunção pela unidade de GP de um lugar no nível estratégico da } \\
\text { organização }\end{array}$ \\
\hline \multirow{5}{*}{ Estrutural } & Mapear e redesenhar os processos de trabalho \\
\cline { 2 - 2 } & Ampliar os canais de informação \\
\cline { 2 - 2 } & Estimular o relacionamento interpessoal entre os servidores \\
\cline { 2 - 2 } & Adotar estruturas de trabalho baseadas em equipes \\
\cline { 2 - 2 } & Adotar sistemas informatizados de GP \\
\cline { 2 - 2 } & Desenhar cargos com atribuições ampliadas \\
\cline { 2 - 2 } & Adotar estruturas organizacionais mais achatadas \\
\cline { 2 - 2 } & Criar novas unidades estruturais \\
\cline { 2 - 2 } & Descentralizar a unidade de GP \\
\hline \multirow{5}{*}{ Cultural } & Implementar programas de capacitação apropriados \\
\cline { 2 - 2 } & Realizar mudanças com a participação dos funcionários \\
\cline { 2 - 2 } & Sensibilizar os colaboradores antes do início de um processo de mudança \\
\cline { 2 - 2 } & Instituir mecanismos de reconhecimento \\
\cline { 2 - 2 } & Realizar estudos para analisar a cultura organizacional \\
\hline
\end{tabular}

Fonte: Adaptado de Castro (2018)

As 17 iniciativas adotadas pelas organizações públicas foram analisadas e, por causa de seu efeito mitigador em pelo menos três fatores interferentes, cinco iniciativas - Figura 4, foram caracterizadas como de maior relevância: "Realizar parcerias estratégicas", "Adotar estruturas 
de trabalho baseadas em equipes", "Descentralizar a unidade de GP", "Implementar programas de capacitação apropriados" e "Realizar mudanças com participação de funcionários" (Castro, 2018, p. 185).

É relevante destacar que a iniciativa de "Realizar parcerias estratégicas" reflete o sucesso de alinhamento estratégico das organizações pesquisadas, pois a unidade de GP se integra à outras unidades organizacionais a partir da formação de parcerias estratégicas com atores e trabalho conjunto aos gerentes de linha (Castro, 2018). Segundo Castro (2018) e sua análise da literatura, a busca por alinhamento estratégico (ajuste e viabilização da gestão estratégica de pessoas) representa a ação conjunta dos diferentes atores centrais da implementação que - através da formação de parcerias, ampliarão o escopo da unidade de GP e favorecerão o sucesso da implementação (Castro, 2018).

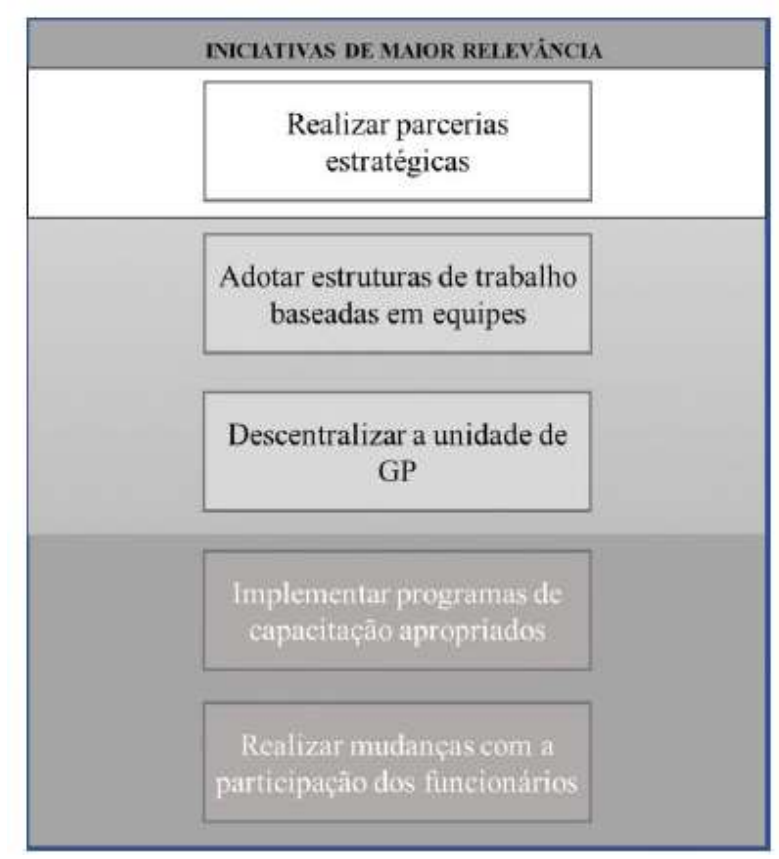

Figura 4. Iniciativas de maior relevância.

Fonte: Castro (2018)

Novamente a iniciativa estratégica se relaciona com o fator do "Papel da unidade de GP na implementação das estratégias organizacionais" e pode haver conexões com a inserção estratégica da unidade de GP. Castro (2018, p. 186) retrata que a iniciativa de parcerias estratégicas reflete na mitigação da interferência do "Papel da unidade de GP", na medida que amplia "o poder de atuação da unidade além de suas competências técnicas e funcionais, potencializando sua atuação, inclusive por meio da realização de parcerias com outras 
organizações". Devido ao arranjo estrutural por vezes dificultar a inserção estratégica da unidade de GP nas arenas decisórias, estratégias informais serão adotadas (Castro, 2018); ou seja, a iniciativa de "Realizar parcerias estratégicas" constitui a tentativa da unidade de GP para a tentativa legítima de acesso às arenas decisórias.

A partir da exploração acerca dos diferentes modelos apresentados, pode-se ratificar a necessidade de considerar a influência dos aspectos políticos sobre qualquer processo decisório da administração pública, assim como na implementação da Gestão Estratégica de Pessoas. Sobretudo, não se trata somente de reconhecer o modelo político na Gestão de Pessoas (Borges \& Mourão, 2013); mas também fundamentar a relevância da inserção estratégica da unidade de GP como fator chave para que o setor alcance posição central na organização, da mesma forma que o setor obterá maior sucesso na implementação de suas políticas. Através da habilidade política da liderança de GP que o setor conquistará parcerias com diferentes gerentes da organização propiciando, portanto, acesso e voz nas arenas decisórias que - consequentemente, modificaram o papel da unidade de GP na implementação de estratégias organizacionais. Todos estes elementos representam faces do fenômeno da inserção estratégica, porém, é necessário analisar outros aspectos na literatura acerca do principal objeto deste estudo.

\subsubsection{Inserção Estratégica das áreas de GP}

A participação da unidade de Gestão de Pessoas nas principais arenas decisórias para o alinhamento entre alta administração sobre as políticas e práticas de Gestão Estratégica de Pessoas, assim como incrementos no planejamento estratégico, corresponde a categoria da inserção estratégica das áreas de GP (Araújo, 2018). Classificado como fator político, explorar as formas como o setor de GP acessa as arenas, participa e influencia o processo decisório é de extrema importância; pois como já foi abordado na literatura, o simples acesso as arenas decisórias reconhece o poder legítimo da GEP e provê a função de GP oportunidades para criar uma visão compartilhada com outros executivos seniores sobre o que a GEP pode contribuir (Sheehan, 2007).

Até o presente momento, foram abordados periódicos que tratam do fenômeno não só no setor público - mas sobretudo a grande maioria de estudos em organizações privadas. A literatura recente aborda as diferentes formas como a inserção estratégica da área de GP se manifesta, portanto, serão abordados os "Papeis da unidade de GP”, "As ações formais e 
informais da área", e "O envolvimento do setor no processo de tomada de decisão" e como estes influem no acesso às arenas; assim como suas ligações com as habilidades políticas de GP.

Sheehan \& De Cieri \& Cooper (2015) abordam como os papeis dos profissionais de GP afetam o fenômeno da inserção estratégica. Estes papeis se referem tanto a unidade de GP, quanto a atribuições específicas dos representantes - ou líderes, da unidade. Os autores abordam a relevância das habilidades políticas, sendo estas definidas como habilidades de interpretar pessoas e situações no trabalho para traduzir este conhecimento em objetivos direcionados para influenciar outros. A partir disso os profissionais de GP ampliam a legitimidade e tornam a função de GP apta para impactar o desempenho organizacional. É através da habilidade política de GP que os profissionais e representantes da unidade gerenciam o compartilhamento de ideias e soluções nas arenas decisórias e em todo ambiente organizacional, além de encorajar todos os atores nos comportamentos esperados e descritos nas políticas de GEP.

Sheehan et al. (2016) aborda alguns fatores que impactam na transição do antigo modelo de administração de recursos humanos para gestão de pessoas, sobretudo nas novas atribuições da unidade de GP. Devido à mudança, a autora retrata a importância do novo papel da liderança de GP para a necessidade de formar parcerias estratégicas com vista ao alinhamento da área com a organização. Buyens \& De Vos (2001) já abordavam este papel e a relevância de reorganizar a função de GP para refletir tarefas operacionais e estratégicas de acordo com as necessidades do negócio organizacional, portanto, atuar sobre a "Coexistência do Papel Funcional de GP" a partir do acesso das arenas decisórias (Araújo, 2018; Côrtes, 2016).

Não só como atribuição ao gerente do setor, mas a função estratégica também requer dos profissionais o entendimento claro de como a gestão de pessoas encaixa - e suporta, a missão e estratégia organizacional tão bem como devem conhecer os processos básicos de negócio. Este novo contexto demonstrou a prática organizacional de repetida reformulação da função de GP. Porém os próprios profissionais da área têm dificuldades para definir suas atribuições, da mesma forma que a literatura não conseguiu definir um modelo principal que abarcasse todas as atribuições da unidade de GP (Sheehan \& De Cieri \& Cooper \& Shea, 2016).

Dado este fato, os papeis dos profissionais de GP tem impacto direto na inserção estratégica. A partir da teoria sobre atribuições de Welch \& Welch (apud 2012), Sheehan (2016) relata que os comportamentos esperados e descritos formalmente para determinado cargo são impactados por normas e crenças geradas em um sistema social. Problemas no controle das 
atribuições pelos profissionais de GP são potencialmente geradas pelo sistema social que o setor está inserido - este marcado não só pelas descrições formais de trabalho, mas também pela competição de expectativas de diferentes atores sobre a unidade de GP. Para ingressarem nas arenas decisórias da organização, a unidade de GP deve estar atenta a diversidade real de papéis desempenhados pelos seus profissionais, assim como gerenciar estas expectativas dos inúmeros atores da melhor maneira possível (Sheehan \& De Cieri \& Cooper \& Shea, 2016; Buyens \& De Vos, 2001).

O pouco tempo disponível aos profissionais de GP - acompanhados da pressão sobre o conflito de expectativas sobre o setor, podem reduzir a confiança nas capacidades estratégicas dos profissionais, assim como impactar as probabilidades de estes estarem incluídos nas discussões formais e informais dos processos decisórios (Sheehan \& De Cieri \& Cooper \& Shea, 2016).

As ações formais e informais da área de GP representam outra face do fenômeno da inserção estratégica, pois os processos de tomada de decisão formais ou informais exprimem formas de acesso ao planejamento estratégico pelos profissionais e representantes de GP (Sheehan \& De Cieri \& Cooper \& Shea, 2016). Sheehan (2005) aborda a necessidade de representação da unidade no ambiente organizacional, à medida que - no processo de tomada de decisão estratégica, argumenta-se que o nível da representação no quadro de diretores é fator crítico, pois é necessário analisar se os gestores de GP têm permissão (ou espaço) apropriado para incrementar às decisões respaldados pelos mecanismos formais de acesso. Porém, sendo a unidade representada ou não, a autora argumenta que isto não diminui a influência no ambiente organizacional por causa de outras formas de envolvimento nos processos decisórios; como o sucesso no desenvolvimento da rede informal de relacionamento do gestor de GP com os executivos chave (Sheehan, 2005).

As ações formais e informais se relacionam com as habilidades políticas de GP a partir de, quanto mais dotados de aptidões políticas, maior as oportunidades para inclusão nos processos de tomada de decisão estratégica (Sheehan, 2015). A literatura aborda aspectos do relacionamento entre os diversos atores organizacionais e a unidade de GP. Os profissionais de GP têm estado inseridos em uma posição que os obriga a exercitar maior influência sem autoridade; pois, eles estão próximos a necessidade de criar e manter a percepção de que a GEP é crítica e estrategicamente importante. Além disso, uma possível resistência na relação entre a unidade, gerentes de linha e grupos executivos; pode minimizar os benefícios das políticas e práticas de GEP. É através de meios formais e informais e das habilidades políticas que 
propiciam o gestor de GP apresentar dos benefícios de cada política, controlar a percepção das informações, manipular as impressões dos atores sobre os valores das iniciativas e fortalecer a conexão entre o conteúdo das práticas de GEP e os objetivos organizacionais (Sheehan, 2015, Buyens \& De Vos, 2001).

Outra face da inserção estratégica da área de GP é o envolvimento da unidade no processo de tomada de decisão. Estar envolvido nos processos estratégicos possibilitam o setor de GP impactar as tomadas de decisão; pois, a maneira e o momento que este se insere revela importantes características (Buyens \& De Vos, 2001). Segundo a literatura, cada tipo de envolvimento - seja na etapa de formulação ou implementação, pode ser importante para a efetivação das políticas de gestão estratégica; porém segundo Buyens \& De Vos (2001, p. 75) de acordo com Dyer (apud, 1983) "quanto mais cedo os profissionais de GP se envolvem no processo, melhor poderá ser o impacto destes sobre as decisões estratégicas”. Estar envolvido cedo na etapa de formulação estratégica aumenta as chances das reivindicações do setor de GP refletirem sobre as metas organizacionais.

Sobre a etapa de formulação estratégica, são retomadas as práticas de ações formais e informais da área de GP. Segundo Dyer (apud, 1983) há duas maneiras de formulação da estratégia: a primeira através do processo formal de planejamento estratégico, padronizado e hierárquico; segundo através de um processo menos formal de base ad hoc que caracteriza a maioria dos processos de formulação estratégica (Buyens \& De Vos, 2001). Para a unidade e gestores de GP, "isto implica que eles devem conhecer os dois processos de formulação estratégica se eles querem estar envolvidos nos estágios iniciais" (Buyens \& De Vos, 2001, p. 75).

Em discordância com Dyer (apud, 1983), Buyens \& De Vos (2001) adotaram o termo "tomada de decisão" ao invés de "formulação estratégica", devido o primeiro estar relacionado a realidade das decisões sobre GP. A partir da análise sobre a literatura, os autores confeccionaram um modelo em que o envolvimento da unidade de GP é representado em diferentes estágios do processo decisório, conforme a Figura 5. 


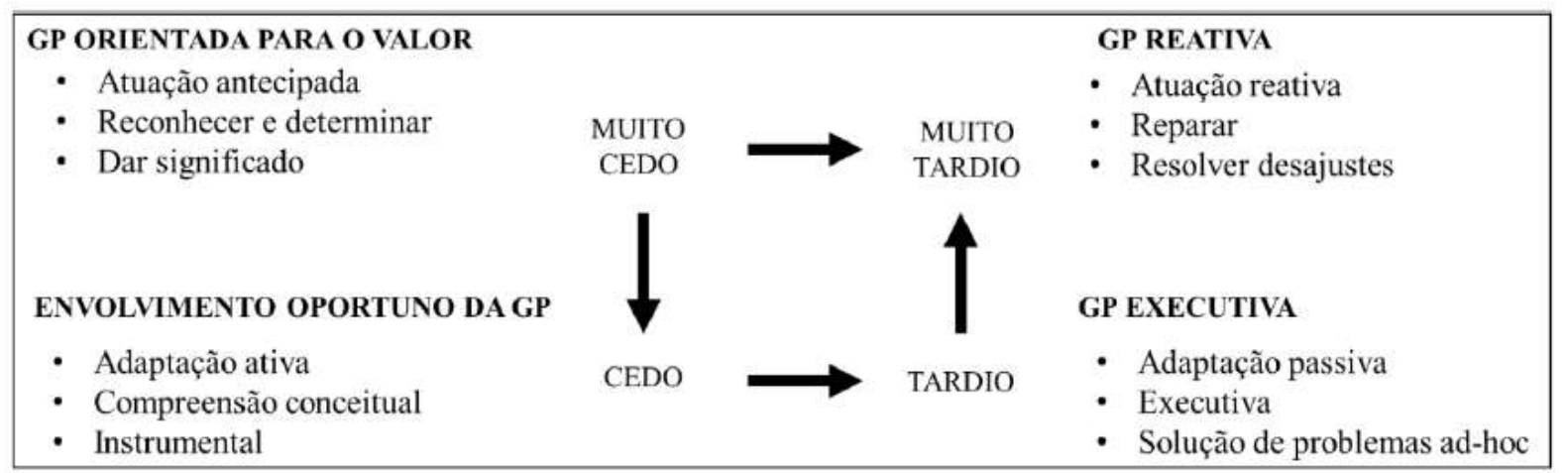

Figura 5. Envolvimento da GP no processo de tomada de decisão.

Fonte: Buyens \& De Vos (2001).

A partir da concordância de que o processo decisório se inicia com a observação das discrepâncias entra a situação atual e a desejada, " GP orientada para o valor” corresponde aos os profissionais do setor que se envolvem no estágio inicial e serem reconhecidos como parceiros estratégicos. "Envolvimento oportuno da GP" se refere os profissionais de GP que são ativamente envolvidos no processo decisório pela criação de instrumentos e suporte aos gerentes de linha responsáveis pela implementação. Se o envolvimento na decisão for caracterizado pela restrição das atividades de GP somente à implementação, sem a possibilidade dos profissionais de GP incrementarem algo na etapa, o envolvimento é a "GP executiva". Por fim a "GP reativa" implica que os profissionais do setor são consultados somente para controle ou se as soluções não trabalham conforme o esperado.

Ressalta-se novamente a importância da unidade se envolver cada vez mais cedo no início do processo decisório, pois através da atuação antecipada que a Gestão Estratégica de Pessoas terá maior impacto na decisão; além dos autores argumentarem que a GEP oferece valor em cada estágio da tomada de decisão (Buyens \& De Vos, 2001). Outro ponto relevante dos autores sobre o modelo confeccionado é que "a queda do envolvimento junto das diferentes decisões tomadas é considerada um indicador de importância e valor que outros atores têm das contribuições vindas da unidade de GP" (Buyens \& De Vos, 2001, p. 76). O envolvimento da unidade de GP representa uma face da inserção estratégica, devido seu nível influenciar nos resultados organizacionais; além de demonstrar como a área é uma importante parceira estratégica. 
De forma geral, a literatura sobre gestão estratégica de pessoas no setor público contém avanços consideráveis - ainda assim é um campo de estudo carente no qual, segundo Côrtes (2016) e Araújo (2018), grande parte das publicações estão centralizadas em pesquisas de natureza técnica em vez de estudos contextuais. Esta conjuntura vai contra a realidade da administração pública, em que se comprova a predominância dos interesses pessoais e políticos - isto retratado em todo este trabalho, acima de critérios técnicos e prioridades organizacionais (Araújo, 2018).

Compreender de que forma o fenômeno da inserção estratégica da área de GP se manifesta - assim como elementos que o circundam, representa não só a necessidade de enfrentamento a contingência política que a produção acadêmica almeja (Araújo, 2018); mas principalmente a tentativa de descrever com fidelidade a realidade de múltiplos interesses dos atores presentes nas arenas decisórias e seu impacto na confecção de políticas. A centralização da análise do ambiente organizacional, a partir da unidade de gestão de pessoas, dos periódicos estrangeiros limitaram a captura de outros elementos essenciais que retratam a complexa multiplicidade de interesses sobre os processos decisórios.

A partir da insuficiência de estudos que demonstram o fenômeno da inserção estratégica na administração pública - especialmente sua relação com a tomada de decisão, arenas decisórias e representantes destas; é necessário recorrer a outro campo científico que apresentam estes e outros elementos do jogo político nas arenas e são variáveis do processo político-administrativo (Rua, 2014; Howllet \& Ramesh \& Perl, 2013; Forester, 1984)

\subsection{Políticas Públicas: conceitos e subsistemas}

Advindo das diversas áreas de conhecimento da Ciência Política, as Políticas Públicas (PPs) foram se consolidando como campo científico, autônomo e incumbido de interpretar os fenômenos político-administrativos no século XX nos Estados Unidos e Europa (Dias \& Matos, 2012; Secchi, 2010). Analisar o papel do Estado e o processo de formação das políticas públicas para resolução de problemas da sociedade é o principal objetivo dos pesquisadores de policysciences, como afirma Secchi (2010, p. 12) que “onde há problemas públicos, a área de políticas públicas dá subsídio para a sua análise e para a tomada de decisão”. No Brasil, o campo inaugurou seus estudos no final da década de 1970 a partir de obras relacionadas a "formação histórica das ações de governo" (Dias \& Matos, 2012, p. XII). 
A evolução do campo científico nos países de língua latina se deu inicialmente pelo reconhecimento da distinção do vocabulário, pois o termo política assume duas conotações na língua inglesa. Secchi (2010) descreve a distinção entre Politics e Policy em que os termos podem: o primeiro significar a ação humana em obter e manter recursos necessários para o exercício do poder, então gerando competição política; o segundo que se refere às "orientações para decisão e ação" (Secchi, 2010, p. 1). Esta distinção se faz necessária devido ao fato de a Política Pública (Public Policy) englobar esta segunda característica, pois se trata da compreensão de múltiplas decisões, do conteúdo político inserido e o impacto produzidos das escolhas governamentais na sociedade (Howlett \& Ramesh \& Perl, 2013).

Coube a literatura definir o conceito de Política Pública, porém não houve unanimidade entre os especialistas devido questionamentos sobre quais os atores - definido com aqueles "que exercem alguma influência sobre os processos e outcomes de uma política pública" (Howlett \& Ramesh \& Perl, 2013, p. 69), que atuam nos processos estatais ou não; se as PPs também remetem à não ação ou negligência do Estado; e se empreendimentos operacionais além dos estruturantes, também fazem parte do escopo conceitual (Secchi, 2010). Independente do obstáculo, mantém-se que as diversas definições de política pública "tentam captar a ideia de que a policy-making é um processo técnico-político que visa definir e compatibilizar objetivos e meios entre atores sociais sujeitos a restrições" (Howlett \& Ramesh \& Perl, 2013, p. 6). É um processo técnico porque aborda a relação mútua entre os diferentes instrumentos e objetivos utilizados na resolução de problemas públicos, sendo estes úteis ou não; assim como também é um processo político porque há divergências dos atores sobre o que forma um problema político e suas melhores soluções (Howlett \& Ramesh \& Perl, 2013).

"Tudo o que um governo decide fazer ou deixa de fazer" (Howlett \& Ramesh \& Perl, 2013, p. 6; apud Dye, 1972, p. 2) é uma das definições mais conhecidas da literatura. Esta definição é tratada pela literatura como simplista visto a complexidade do tema, porém ela retrata três aspectos importantes analisados por Howlett \& Ramesh \& Perl (2013): (i) ela especifica o agente principal do processo político-administrativo que é o governo; (ii) evidencia que a policy-making compreende que a tomada de decisão governamental inclui agir ou manter o status quo de um problema; e (iii) que a política pública é uma ação consciente dos governos, pois qualquer decisão pode produzir externalidades negativas e não esperadas em que o autor as caracteriza como subprodutos.

Howlett \& Ramesh \& Perl (2013) também ressaltam a importância da definição de Jenkins (apud, 1978) devido à sua utilidade em clarificar os instrumentos e objetivos do 
conteúdo da política, assim como o caráter de decisões inter-relacionadas tomadas por diferentes atores no processo político-administrativo; portanto atribui-se um nível maior de complexidade ao conceito de política pública pelo conjunto cumulativo de decisões que gerarão efeitos ou impactos.

Jenkins (1978) defini a política pública como 'um conjunto de decisões interrelacionadas, tomadas por um ator ou grupo de atores políticos, e que dentro de uma situação específica em que o alvo dessas decisões estaria, em princípio, ao alcance desses atores' (Jenkins, 1978) (Howlett \& Ramesh \& Perl, 2013, p. 8).

Outras definições permeiam a literatura como: "Políticas públicas são a totalidade de ações, metas e planos que os governos (nacionais, estaduais ou municipais) traçam para alcançar o bem-estar da sociedade e do interesse público" (Sebrae, 2008, p. 5); e "fluxo de decisões públicas, orientado a manter o equilíbrio social ou a introduzir desequilíbrios destinados a modificar essa realidade" (Saravia, 2006, p. 28).

Mais do que a adoção de um conceito, o importante é compreender as abordagens teóricas que conduzem os estudos de políticas públicas. Devido o foco do objeto de estudo não ser a análise de múltiplas lentes, algumas serão tratadas brevemente. A literatura retrata diferentes abordagens de análise, algumas classificadas de multidisciplinares (Howlett \& Ramesh \& Perl, 2013) por causa dos diferentes campos - como Geografia, História, Psicologia, Sociologia, Economia e Ciência Política - que as produziram; outras categorizadas por Secchi (2010) de estatista ou estadocêntrica e multicêntrica.

Entre as multidisciplinares, a teoria da escolha pública (Public Choice) está alicerçada em valores da economia neoclássica com objetivo de análise comportamental dos atores políticos, partidos, burocratas e eleitores que procuram agir racionalmente de maneira individualista na intenção de maximizar seus lucros, ou seja; são dirigidos por aquilo que lhes é benéfico (Howlett \& Ramesh \& Perl, 2013). Por conseguinte, haverá aumento da intervenção estatal na economia em que serão oferecidas soluções (políticas e programas) para elevar o nível de popularidade dos parlamentares. O combate deste comportamento egocêntrico se dará através da fundação e desenvolvimento de instituições que limitaram as ações de todos os atores (Howlett \& Ramesh \& Perl, 2013).

Alguns críticos da public choice argumentaram contra a concentração das análises sobre o indivíduo, visto que simplificava por demais o estudo de políticas públicas; portanto, novas teorias surgiram "para explicar toda a amplitude do comportamento social e da atividade organizacional que alicerça a policy-making” (Howlett \& Ramesh \& Perl, 2013, p. 50). A teoria 
neoinstitucionalista, ou institucionalista centrada no ator, argumenta que o ambiente tem maior influência sobre o comportamento humano, pois a forma como regras, normas, símbolos e instituições do governo estão configuradas resultam na futura limitação de escolhas para soluções de problemas públicos (Howlett \& Ramesh \& Perl, 2013). Os atores políticos, mesmo dotados de interesses individuais e coletivos, só concretizaram suas intenções por meio dos instrumentos normativos pré-estabelecidos pelas instituições. Porém a abordagem não explica como as mesmas instituições e regras são criadas e alteradas (Howlett \& Ramesh \& Perl, 2013).

No intuito de solidificar uma base para a teoria de políticas públicas, surge uma nova lente a partir do institucionalismo envolto pela sociologia e história. A abordagem estatista se iniciou no século XX a partir de estudos sobre como o desenvolvimento da sociedade é influenciado pelas instituições criadas no Estado moderno (Howlett \& Ramesh \& Perl, 2013). Segundo Secchi (2010, p. 3). As políticas públicas são exclusividade do Estado em que este é o principal ator pois, além de produzir leis e garantir seu cumprimento, ele é o único dotado de superioridade hierárquica para retificação de possíveis "desvirtuamentos que dificilmente mercado e comunidade conseguem corrigir sozinhos". Outro ponto da ótica estatista é o estudo necessário do contexto social em que o Estado está introduzido, visto que facilita a compreensão das preferências e práticas políticas (Howlett \& Ramesh \& Perl, 2013).

Porém Secchi (2010) levanta críticas ao estadocentrismo ao retratar que o Estado não é o principal agente de elaboração de políticas públicas. $\mathrm{O}$ autor defende estudos policêntricos da política - que propagam a existência de inúmeros centros decisórios regimentados por regras respeitadas, por conseguinte "as políticas públicas são elaboradas dentro do aparato institucional-legal do Estado, embora as iniciativas e decisões tenham diversas origens" (Secchi, 2010, p. 3). A abordagem multicêntrica contém enfoque interpretativo do que é uma política pública, à medida que analisa o entendimento de inúmeros atores políticos sobre os problemas públicos. Além disso, permite-se a análise de fenômenos político-administrativos não estatais através dos aparatos instrumentais e conceituais da área de políticas públicas (Secchi, 2010). Outro ponto recai sobre a existência não só dos instrumentos legais e punitivos criados pelo Estado para garantir a execução de suas políticas, mas também dos instrumentos de política pública (informação, incentivos positivos, prestação de serviços) revelando, pois, que não há só mecanismos de coerção (Secchi, 2010).

Howlett \& Ramesh \& Perl (2013) também retratam as debilidades da abordagem estatista sobre o excesso de foco no Estado, assim como a impossibilidade de explicar como os Estados não conseguem concretizar suas vontades em tempos de crise, tal qual a existência de 
liberdades individuais e privilégios sociais. Mas os autores ressaltam que a exacerbação Estadocêntrica foram escritas por poucos e que a abordagem não elimina por completo a participação de múltiplos atores, em vez disso eles afirmam que é necessário explorar as diversas estruturas do Estado sobre as relações políticas - todas influentes no processo político-administrativo. Por fim, defende-se que o estatismo salienta as relações entre o Estado e a sociedade pois:

Vê-se o Estado com um ator autônomo com a capacidade de divisar e implementar
seus próprios objetivos; ele não responde necessariamente apenas à pressão dos
grupos ou das classes sociais dominantes. Sua autonomia e capacidade derivam de seu
corpo de funcionários, que têm ambições pessoais e interesses organizacionais, bem
como do fato de ser uma organização soberana, com recursos financeiros, de pessoal
e, em última instância, de coerção sem paralelos (Howlett \& Ramesh \& Perl, 2013, p.
54).

Feita a descrição das diferentes abordagens para estudo das políticas públicas, compete este trabalho discorrer sobre o ciclo político-administrativo (Policy Cycle). Os inúmeros detalhes que elevaram a dificuldade de interpretação sobre os estudos políticos fomentaram nos pesquisadores na busca por meios populares para simplificar a policy-making. Percebeu-se que a divisão por etapas interconectadas como um processo possibilitou, aos pesquisadores e inexperientes, melhor compreensão e análise (Howlet \& Ramesh \& Perl, 2013; Dias \& Matos, 2012; Secchi, 2010; Souza, 2006).

São importantes dois aspectos a serem tratados sobre o ciclo de políticas públicas: primeiro, que sua adoção pelos especialistas partiu da lógica para resolução aplicada à problemas, pois a divisão em etapas e subetapas facilita a investigação de elementos isolados ou relacionados a outros estágios do ciclo (Howlett \& Ramesh \& Perl, 2013). Esses elementos se referem as relações de poder, redes políticas e sociais, atores, restrições, decisões e resultados que podem ser próprios de uma ou mais etapas do ciclo, além de estarem em constante interação recíproca (Dias \& Matos, 2012). O segundo aspecto é a não linearidade do policy cycle, ou seja, os policy-makers não resolvem problemas públicos de maneira sistemática; mas "os estágios são, muitas vezes, comprimidos ou evitados, ou são seguidos numa ordem diferente da especificada pelo modelo" (Howlett \& Ramesh \& Perl, 2013, p. 16).

Os estágios no ciclo político são: (i) montagem da agenda, que "se refere ao processo pelo qual os problemas chegam à atenção dos governos" (Howlett \& Ramesh \& Perl, 2013, p. 14); (ii) formulação da política, que trata de que forma as propostas políticas são elaboradas no sistema governamental; (iii) tomada de decisão, o processo em que os governos optam por ato específico de intervir ou se manter inerte; (iv) implementação da política, que está relacionado "ao modo pelo qual os governos dão curso efetivo a uma política" (Howlett \& Ramesh \& Perl, 
2013, p. 15); e (v) avaliação da política, quando os resultados da política são monitorados por diferentes atores gerando retroalimentação do ciclo em um ou mais estágios. Para cumprir os objetivos deste trabalho, serão abordados em maior grau os estágios da tomada de decisão e implementação devido suas particularidades; mas os demais também serão citados no decorrer da exposição devido à não linearidade já abordada.

A literatura especializada em PPs constantemente aborda o termo "atores", aqueles com influência direta ou indireta sobre o conteúdo e resultados do processo político-administrativo (Secchi, 2010). Como retratado anteriormente, a abordagem estatista tem preocupação em levantar variáveis como estruturas e atores para análise de políticas. Secchi (2010) ao analisar os diferentes tipos de atores, propôs a classificação destes em dois grandes grupos. A primeira categoria compõe os atores governamentais: políticos, designados politicamente, burocratas e juízes. Grupos de interesse, partidos políticos, meios de comunicação, think tanks, destinatários das políticas públicas, organizações do terceiro setor, especialistas, financiadores e etc., representam a categoria de atores não governamentais. É essencial abordar quatro tipos de atores, devido sua frequência na literatura.

Atores políticos são cruciais no processo de políticas públicas, à medida que (empossados em cargos do Legislativo ou Executivo) identificam os problemas públicos e determinam quais PPs serão prioritárias no combate à situação (Secchi, 2010). Outro aspecto é que eles são os detentores legítimos e institucionais da tomada de decisão, porém - mesmo que principais, estão sujeitos a representar interesses próprios, de partidos políticos, grupos de pressão e categorias profissionais; todos inúmeras vezes conflitantes (Secchi, 2010). Atores designados politicamente descrevem "uma faixa intermediária de cargos públicos ocupada por pessoas indicadas pelo político eleito para servir em funções de chefia, direção e assessoramento na administração pública" (Secchi, 2010, p. 103). Esses atores têm bastante impacto na administração pública visto estes serem constituídos de poder no objetivo de transmitirem as orientações políticas a todo corpo burocrático (Secchi, 2010).

Burocratas são, diversas vezes, chave no processo político-administrativo e podem exercer forte influência no contexto da política, pois são regimentados por legislação própria com carreiras longas e estáveis. Seus conhecimentos técnicos subsidiam políticos na escolha de soluções (estágio de formulação da política) e ressaltam a dependência destes representantes ao corpo burocrático, conforme afirmam Howlett \& Ramesh \& Perl (2013, p. 75) que a "autonomia da burocracia em relação às forças políticas e aos grupos societários também contribui para sua força e eficácia na policy-making”. 
Grupos de interesse, também conhecidos como grupos de pressão, são grupos de pessoas organizados voluntariamente que influenciam as políticas públicas - sobretudo as decisões, através da utilização de recursos financeiros, cognitivos e organizacionais (Secchi, 2010). Sindicatos, associações comerciais e movimento sociais são exemplos de grupos de interesse. Segundo Secchi (2010), os grupos de pressão podem ser analisados por duas perspectivas: primeiro como "patologia do sistema democrático, pois conseguem desvirtuar, a seu favor as decisões sobre políticas públicas" (Secchi, 2010, p. 109); ou são compreendidos como naturais para as políticas públicas, à medida que a variação de recursos - assimetria dos grupos, determina a prevalência de um grupo sobre outro.

Discorridos a capacidade destes quatro atores sobre a política pública, é perceptível que a literatura demonstra a importância de conhecer quem são os atores incluídos no processo político-administrativo, devido a influência que cada um destes pode exercer. Este aspecto é relevante para a compreensão do processo de inserção estratégica. Será tratado na seguinte sessão em detalhes de que forma ocorre as decisões e implementação de políticas segundo a literatura.

\subsubsection{Tomada de decisão e implementação de políticas públicas}

Após o debate e exame das diversas alternativas para o problema público nos estágios anteriores, a tomada de decisão compreende o momento específico de escolha e aprovação de uma ação oficial (Howlett \& Ramesh \& Perl, 2013). A literatura evidencia, neste estágio, o confronto de posicionamentos do maior número possível de atores no ciclo político, além de retratar que as decisões muitas vezes são caracterizadas como não racionais ou incoerentes mas que possibilitam equacionar os interesses e as intenções (objetivos e métodos) dos atores envolvidos (Howlett \& Ramesh \& Perl, 2013; Dias \& Matos, 2012; Secchi, 2010).

Howlett \& Ramesh \& Perl (2013) destacam uma importante característica do estágio da tomada de decisão que é o seu não exercício técnico, mas visível caráter político. Este ponto ressalta o conflito entre atores em torno das decisões, sendo que estas disputas públicas ocorrem no espaço, ambiente ou cena (contexto interativo ou sistêmico) onde este é denominado pela literatura de "arena política" por Reis (2013) e Rua (2014) - ou "arena decisória” por demais aqui citados (Howllet \& Ramesh \& Perl, 2013; Dias \& Matos, 2012; Secchi, 2010). O uso dos termos é bastante comum na literatura em que estes se referem ao local onde são tomadas as 
decisões, ou onde ocorrem o processo decisório - portanto não há distinção entre os termos (Reis, 2013). As particularidades da arena política irão estabelecer o jogo político, ou seja, como ocorre o processo decisório; pois sua configuração está em conformidade com as instituições decisórias em rigor; a configuração organizacional dos grupos; e as prioridades estratégicas dos competidores.

Lowi (1964, apud 1992) foi responsável por desenvolver as tipologias sobre política pública e, conforme sua obra, os tipos de política têm relação direta com as quatro configurações possíveis de arena política. Além de retomar os conceitos do autor, Rua (2014) descreve o comportamento político dos atores em cada arena. (i) As arenas distributivas estão relacionadas com as políticas distributivas, "decisões tomadas pelo governo, que desconsideram a questão dos recursos limitados, gerando impactos mais individuais do que universais, ao privilegiar certos grupos sociais ou regiões, em detrimentos do todo" (Souza, 2006, p. 28). Em relação aos atores, há pouca disputa entre este tipo de política - pois não é possível mensurar o quanto cada ator terá que despender pela política, ou seja, seu custo (Rua, 2014). O conflito provável de políticas distributivas recaí sobre a ampliação dos benefícios ou inclusão de novos beneficiários (Rua, 2014).

(ii) Políticas redistributivas "impõem perdas concretas e no curto prazo para certos grupos sociais, e ganhos incertos e futuro para outros; são, em geral, as políticas sociais universais, o sistema tributário, o sistema previdenciário e são as de mais difícil encaminhamento" (Souza, 2006, p. 28). As arenas redistributivas são descritas como jogo de soma-zero, pois o sucesso de alguns atores resulta no fracasso de outros (Rua, 2014). (iii) Responsável por determinar regulamentos, as políticas regulatórias contêm alta possibilidade de conflito, visto que resulta estabelecer regras, sanções e critérios para o acesso de recursos; portanto, a arena regulatória representa um embate entre beneficiados e prejudicados (Rua, 2014). (iv) As políticas constitucionais contêm caráter estruturador, pois criam e modelam instituições; modificam o sistema de governo; e os processos de negociação, cooperação e consulta entre diferentes atores (Rua, 2014). Devido sua característica de formular o aparato geral para negociação de demais políticas, a "arena constitucional é abrangente, centralizada e fortemente coercitiva" (Rua, 2014, p. 74).

Ao abordar sobre a dinâmica das relações entre os atores, Rua (2014) destaca lutas, jogos e debates como três padrões possíveis. O contexto de conflito e confronto, advindo da condição em que um ator ganhar e outro perde é chamado de lutas (Rua, 2014). Porém a autora destaca a possibilidade de os atores entrarem em acomodação, evitar o conflito 
temporariamente e ceder em alguns pontos, como estratégia para adiar o conflito para momento oportuno. Sobre os jogos, refletem a competição entre atores que não visam eliminar por completo o adversário, mas podem se tornar aliados através de negociações ou barganhas (Rua, 2014). Outro fator dos jogos é a criação de acordos ou alianças para atingir objetivos mútuos, chamado de coalizão, em que "os atores constroem alianças com base em um pequeno ponto de interesse comum, embora permaneçam suas divergências com relação a muitos outros temas" (Rua, 1024, p. 76). Alianças para prejudicar terceiros é chamado de conluio (Rua, 2014).

Por último, os debates retratam a exposição de pontos de vista e propostas no cunho de convencer o adversário da melhor argumentação e transformá-lo em aliado (Rua, 2014). O uso de recursos (conhecimento técnico) para busca de adesão é caracterizado como fator de persuasão; assim como o intercâmbio é bastante utilizado pelos atores sendo a troca de favores, benefícios e apoios (Ruas, 2014). Quando estes últimos não garantem sucesso na formação de aliança, os atores podem utilizar de ameaças - "promessas de imposição de danos ou prejuízos ou de suspensão de favores ou benefícios” (Rua, 2014, p. 77), ou exercício da autoridade direta (A ordena e B obedece) ou indireta (A ordena a B, que ordena a C, e então C obedece).

Visto o conceito de arena política e os comportamentos possíveis dos atores, cabe abordar os modelos de tomada de decisão. O modelo racional foi o pioneiro ao determinar que a tomada de decisão política incluía reunir informações sobre a política e, através de métodos científicos, avaliar e optar pelas soluções "maximizadoras para problemas complexos" (Howlett \& Ramesh \& Perl, 2013, p. 161). Os tomadores de decisão são técnicos que, além de coletar a analisar dados relativos à política, buscam eficácia e eficiência na solução de problemas públicos (Howlett \& Ramesh \& Perl, 2013). O modelo perdeu apoio à medida que a literatura comprovou a não escolha racional dos tomadores de decisão, mas sim baseadas em aspectos ideológicos, culturais, profissionais ou aleatórios. Outro ponto foi o não conhecimento, na prática, das consequências de cada decisão pelos seus tomadores (Howlett \& Ramesh \& Perl, 2013).

Surge o modelo incremental quando seus pesquisadores afirmam que os recursos para uma política pública "não partem do zero e sim, de decisões marginais e incrementais que desconsideram mudanças substantivas nos programas públicos” (Souza, 2006, p. 29). É previsto como inerente a existência de barganhas e concessões no processo político-administrativo, em razão das decisões refletirem a viabilidade política - ao invés da melhor escolha técnica (Howlett \& Ramesh \& Perl, 2013). A característica incremental nas políticas advém do comportamento dos governos se firmarem na análise de decisões passadas para orientar 
processos decisórios futuros, pois a familiaridade constitui um forte peso para mudanças marginais em relação às vigentes (Souza, 2006; Howlett \& Ramesh \& Perl, 2013). As limitações do modelo como sua não orientação para objetivos; não análise dos efeitos do aumento no número de atores; e os efeitos de uma nova política sobre o processo decisório (Howlett \& Ramesh \& Perl, 2013).

As lacunas teóricas e práticas dos modelos anteriores subsidiaram a literatura na produção de novas teorias que ou tentaram romper, ou propuseram um equilíbrio entre as duas. Howlett \& Ramesh \& Perl (2013) retratam outros modelos como da "cesta de lixo" ou garbage can, modelo da "decisão por acreção", modelo do mixed scanning, etc.; que trouxeram diversas contribuições para o entendimento do complexo processo político decisório. Não houve um modelo que pudesse representar com máxima fidelidade as importantes variáveis do processo decisório, porém o modelo sobre os estilos de tomada de decisão confeccionado por Forester (1984, apud 1989) é considerado como promissor na tentativa de unificar teoria e prática (Howlett \& Ramesh \& Perl, 2013).

Forester (1984) retoma os dois modelos pioneiros da tomada de decisão - racionalismo e incrementalismo, e suas limitações para afirmar a dificuldade real da existência de todas as pressuposições necessárias para a tomada de decisão pregadas por cada constructo. $\mathrm{O}$ autor não exclui por completo a possibilidade de ocorrência das pressuposições - e sim retifica a existência de algumas destas na prática, mas ele argumenta que o tomador de decisão deve seguir a estratégia que for viável ao contexto: "Novamente, o que é prático - e racional, a fazer numa situação depende em parte da estrutura daquela situação. Então a análise situacional do tomador de decisão por si só é essencial para a escolha e direcionamento da ação para a situação" (Forester, 1984, p. 25).

A partir da comparação com vertentes compatíveis ao racionalismo (types of Boundedness of Rationality), Forester (1984) pontua que as variáveis agente ou ator (agent), informação (information), tempo (time), definição do problema (problem) e cenário (setting); determinam os estilos da tomada de decisão conforme retratam Howlett \& Ramesh \& Perl (2013, p. 175):

Assim, o número de agentes (atores e tomadores de decisão) pode se expandir quase ad infinitum; o cenário pode incluir muitos tipos diferentes de organizações e pode ser mais ou menos aberto a influências externas; o problema pode ser ambíguo ou suscetível a múltiplas interpretações competitivas; a informação pode ser incompleta, enganosa ou intencionalmente retida ou adulterada; e o tempo pode ser limitado ou artificialmente restringido e manipulado. 
Conforme a variação destes elementos, Forester (1894) propôs cinco estratégias para a tomada de decisão. (i) A otimização (Optimize ou Solve) como estratégica é representada pelo cenário perfeito do método racional visto que: só há um agente para considerar e este busca maximizar sua escolha; o canário é simples e fechado a influências de outros agentes (Howlett \& Ramesh \& Perl, 2013); o problema está bem definido pois seu escopo, valores ou custos, dimensões e consequências estão claras; a "informação é perfeita, completa, acessível e compreensível" (Forester, 1984, p. 25); e o tempo é infinito

(ii) O estilo satisfatório (Satisfice) como estratégia ocorre em estruturas de limites cognitivos - modelo da racionalidade limitada de Simon (apud, 1955), devido a existência de um único agente que agora não seguirá os ditames matemáticos de maximização (Forester, 1984). O cenário é aberto ao ambiente, em que o tomador de decisão pode analisar o comportamento de outros; o problema já não está bem definido e seu escopo é ambíguo; a informação está incompleta; e o tempo é finito (Forester, 1984). O estilo satisfatório será adotado, à medida que os tomadores de decisão buscam por soluções que atinjam a satisfação, portanto, sendo obrigados a diminuir as expectativas de sucesso (Forester, 1984).

(iii) A estratégia como estilo de sondagem (Social Intelligence Networks) caracteriza-se pela participação de burocratas, tomadores de decisão, população e etc., ou seja - pela existência de diferentes atores; o cenário "do tomador de decisão não é somente seu escritório, mas inclui vários outros, cada qual com pessoas relevantes, todas conectadas" por diversos canais de comunicação (Forester, 1984, p. 26); a definição do problema contém múltiplas interpretações dos atores e é possível os tomadores de decisão apreciarem aspectos que os demais não; a informação contém altas variâncias quati e qualitativas, além de menor acessibilidade; e o tempo se torna um recurso social desigual, pois cada ator terá diferentes somas de tempo para dedicação ao problema (Forester, 1984). O autor retrata que a estratégia dos tomadores de decisão é a busca por redes de contato, ou seja, estabelecem alianças entre diversos atores, cultivam bons relacionamentos de trabalho com contatos de organizações similares ou não, assim como em diferentes níveis de governo. O ambiente complexo e variável de relações instiga que o tomador de decisão adapte suas práticas - como utilizar o conhecimento técnico para angariar alianças, de acordo com a situação (Forester, 1984).

(iv) O estilo de tomada de decisão barganha (Bargain ou Increment) abarca confrontos e resistências dos atores que forjam suas alianças, são leais aos próprios interesses ou buscam proteger suas organizações, status e benefícios (Forester, 1984). O autor ressalta o vínculo das teorias pluralista e de grupos de interesse com o estilo de barganha, devido estas explanarem o 
ambiente, pois: "toda organização reflete a mobilização particular de interesses e preferências, assim como formuladores e administradores públicos rotineiramente se encontram confrontados por diversas e conflituosas reivindicações de competitivos interesses, advindos de diferentes atores (Forester, 1984, p. 27). O cenário é "agora caracterizado por diferentes níveis de organização, acesso e interesses" (Forester, 1984. p. 27); a definição do problema é múltipla e plural, pois há diferentes grupos de interesse com opiniões e senso próprios sobre o assunto; as informações se tornam um importante recurso político podendo ser distorcida, manipulada e contestada; tempo permite a formação de alianças, contatar outros atores da rede de contatos e permitir geração de pesquisas para obter mais informações (Forester, 1984).

A estratégia dos tomadores de decisão se associam às ideias incrementais de Lindblom (apud 1955, 1958, 1959), devido ao estilo de barganha que guiará os atores na inserção de pequenas mudanças nas políticas, conforme afirma Forester $(1984$, p. 27) que este ambiente "é composto por conflito de interesses, e o compromisso incremental é a ordem do dia". O autor também ressalta a relação direta entre o nível de complexidade do ambiente na tomada de decisão e a práticas estratégicas que, se o primeiro aumentar, as práticas tenderam a mudanças.

(v) Por fim, a última estratégia é a organizacional (Antecipate ou Organize ou Democratize) em que Forester (1984) aborda o nível de complexidade existente não só no setor público, mas em toda sociedade. O pluralismo levanta alguns entraves porque, na prática, nem todos os atores são integrantes de um grupo de interesse, pois - se o fossem, não haveria como distingui-los. O autor retrata a teoria política da palavra "poder" através da argumentação de que este não é difundido de igual maneira na sociedade, pois há inúmeras desigualdades sóciopolíticas. Portanto, Forester (1984, p. 28) afirma que "o poder e a habilidade para agir e investir nesta sociedade são desigualmente distribuídos, e esses contrastes propiciam e moldam o contexto onde formuladores e gestores públicos - sendo mais comum a tomadores de decisão, trabalham e agem".

O estágio organizacional se refere a um ambiente em que atores estão organizados em uma estrutura social, política e econômica bastante diversificada, portanto o contexto afirma um pluralismo exacerbado (diferente do anterior) “onde estrutura e poder são elementos raramente separáveis" (Forester, 1984, p. 28); os problemas são definidos a partir do reflexo das fontes sociais (Forester, 1984); a informação também é reflexo dos interesses de participantes no processo decisório na busca por verem representados na política seus objetivos independentes (Forester, 1984); e o tempo é caracterizado como poder, mas que não é distribuído igualitariamente. De acordo com o contexto vigente, ideias incrementais são 
insuficientes para sanar as desigualdades existentes, portanto, a orientação é a adoção a estratégias de reestruturação: "estratégias que trabalham na direção para igualdade efetiva, participação democrática e voz" (Forester, 1984, p. 28). Estratégias para formular políticas reformistas e redistributivas; empoderar a população alterando "as estruturas de poder na sociedade" (Forester, 1984, p. 29); e direcionar o trabalho de gestores públicos e formuladores para mudanças política e econômica, através da parceria com movimentos sociais, serão tomadas neste estágio (Forester, 1984). A Tabela 5 sintetiza os estilos possíveis de tomada de decisão e suas variáveis.

\section{Tabela 5. Estilos de tomada de decisão}

\begin{tabular}{|c|c|c|c|c|c|c|}
\hline \multirow{2}{*}{$\begin{array}{l}\text { Modelos de tomada } \\
\text { de decisão (Types of } \\
\text { Boundedness } \\
\text { Rationality) }\end{array}$} & \multicolumn{6}{|c|}{ Condições das Variáveis (Conditions of Administrative/Planning Action) } \\
\hline & Ator & Contexto & Problema & Informação & Tempo & $\begin{array}{l}\text { Estratégia } \\
\text { prática }\end{array}$ \\
\hline $\begin{array}{l}\text { Racionalismo/ } \\
\text { Compreensiva }\end{array}$ & $\begin{array}{l}\text { Um ator racional } \\
\text { decide e } \\
\text { executa }\end{array}$ & $\begin{array}{l}\text { Sistema } \\
\text { fechado }\end{array}$ & $\begin{array}{l}\text { Bem } \\
\text { definido }\end{array}$ & Perfeita & $\begin{array}{l}\text { Infinito ou } \\
\text { sempre } \\
\text { suficiente }\end{array}$ & $\begin{array}{l}\text { Otimização (i), } \\
\text { técnicamente } \\
\text { perfeita, ótima }\end{array}$ \\
\hline Limitação Cognitiva & $\begin{array}{l}\text { Ator não racional, } \\
\text { falível }\end{array}$ & $\begin{array}{l}\text { Sistema } \\
\text { aberto para o } \\
\text { ambiente }\end{array}$ & $\begin{array}{l}\text { Definido de } \\
\text { forma } \\
\text { imprecisa, } \\
\text { ambíguo }\end{array}$ & Imperfeita & Limitado & $\begin{array}{l}\text { Satisfatório } \\
\text { (ii), baseada em } \\
\text { baixas } \\
\text { expectativas e } \\
\text { satisfação }\end{array}$ \\
\hline Diferenças sociais & $\begin{array}{l}\text { Diversos atores } \\
\text { e competências em } \\
\text { coperação }\end{array}$ & $\begin{array}{l}\text { Sistema } \\
\text { aberto com } \\
\text { diversos } \\
\text { canais }\end{array}$ & $\begin{array}{l}\text { Interpretaçã } \\
\text { o variável a } \\
\text { cada ator }\end{array}$ & $\begin{array}{l}\text { Qualidade } \\
\text { acesso } \\
\text { variados }\end{array}$ & $\begin{array}{l}\text { Varia } \\
\text { entre } \\
\text { atores }\end{array}$ & $\begin{array}{l}\text { Sondagem (iii), } \\
\text { atuação em } \\
\text { redes }\end{array}$ \\
\hline Pluralista & $\begin{array}{l}\text { Atores competindo } \\
\text { organizados em grupos } \\
\text { de interesse }\end{array}$ & $\begin{array}{l}\text { Sistema } \\
\text { organizado } \\
\text { por } \\
\text { variações de } \\
\text { acesso }\end{array}$ & $\begin{array}{l}\text { Multiplas } \\
\text { definições } \\
\text { de valores, } \\
\text { impactos e } \\
\text { direitos }\end{array}$ & $\begin{array}{l}\text { Contestada e } \\
\text { aceita como } \\
\text { manipulada }\end{array}$ & $\begin{array}{l}\text { Tempo é } \\
\text { poder }\end{array}$ & $\begin{array}{l}\text { Barganha (iv), } \\
\text { Incremental, } \\
\text { com variações e } \\
\text { ajustes }\end{array}$ \\
\hline Limitação estrutural & $\begin{array}{l}\text { Atores em estruturas } \\
\text { políticas e econômicas } \\
\text { com desigualdade }\end{array}$ & $\begin{array}{l}\text { Sistema } \\
\text { organizado } \\
\text { por } \\
\text { variações de } \\
\text { poder }\end{array}$ & $\begin{array}{l}\text { Definições } \\
\text { em bases } \\
\text { ideológicas }\end{array}$ & $\begin{array}{l}\text { Desinformação } \\
\text { ideológica e } \\
\text { vinculada ao } \\
\text { poder }\end{array}$ & $\begin{array}{l}\text { É poder e } \\
\text { é limitado } \\
\text { conforme } \\
\text { interesse } \\
\text { dos atores }\end{array}$ & $\begin{array}{l}\text { Organizaciona } \\
\mathbf{l}(\mathbf{v}), \text { Baseada } \\
\text { em antecipação, } \\
\text { neutralização, } \\
\text { organização }\end{array}$ \\
\hline
\end{tabular}

Fonte: Forester (1984), traduzido por Dagnino (2002) e adaptado pelo autor. 
O modelo de Forester (1984) representou um avanço na literatura se comparado aos modelos anteriores sendo considerado o primeiro passo para evolução da temática (Howlett \& Ramesh \& Perl, 2013). Mesmo com as limitações do modelo como sua classificação em cinco estilos, podendo serem definidas outras, e a dificuldade de distinção prática entre os estilos (Howlett \& Ramesh \& Perl, 2013); este será adotado para o desenvolvimento do trabalho. Os estilos de Forester (1894) propiciam compreensão da complexidade sobre o estágio da tomada de decisão ao determinar variáveis que a afetam, além de possibilitar insumos na previsão dos impactos de uma determinada política, conforme afirmam Howlett \& Ramesh \& Perl (2013, p. 177): “O foco nessas variáveis pode ajudar a prever o tipo de outcome que provavelmente surgirá do estilo de tomada de decisão adotado no processo político em questão”.

O estágio de implementação no ciclo político-administrativo compreende uma das etapas mais importantes, pois a política se corporifica transformando teorias, normas e decisões em ações (Dias \& Matos, 2012; Secchi, 2010). Considerar somente aspecto técnicos de gestão pública, e não sua dimensão política e os conflitos existentes, é um equívoco; pois ótimas formulações podem acompanhar péssimas implementações (Dias \& Matos, 2012; Secchi, 2010). O estágio não deve ser visto como simplista, devido à diversidade de atores que serão impactados direta ou indiretamente pelo processo de concretização da política.

Os estudos da fase de implementação contêm grande relevância para os pesquisadores, pois permitiu "visualizar, por meio esquemas analíticos mais estruturados, os obstáculos e as falhas que costumam acometer" (Secchi, 2010, p. 56); assim como explorar e interpretar erros de estágios anteriores. A literatura procurou logo produzir modelos que pudessem facilitar a compreensão do estágio de implementação de políticas públicas; logo Howlett \& Ramesh \& Perl (2013) retratam o debate em torno das duas óticas de análise mais conhecidas. O modelo ou perspectiva top-down ou "de cima para baixo" é caracterizado pela separação entre políticos e o corpo burocrático em que, os primeiros representam os tomadores de decisão e os últimos os implementadores (Howlett \& Ramesh \& Perl, 2013; Secchi, 2010; Dias \& Matos, 2012). Outro aspecto é a "primazia hierárquica da autoridade" e "clara separação, tanto conceitual como temporal, entre formulação e a decisão política" da implementação (Dias \& Matos, 2012, p. 81).

Com a realização de novas pesquisas e exame acurado dos afetados e engajados pelo processo de implementação, a perspectiva bottom-up ou "de baixo para cima" argumenta que 
burocratas e rede de atores possuem autonomia no modo de implementar políticas públicas (Howlett \& Ramesh \& Perl, 2013; Secchi, 2010). A eficácia do estágio provinha da forma como os burocratas de nível de rua (Lotta, 2012; apud Lipsky, 1980) - servidores que trabalham diretamente com a sociedade e representam a própria política, se adaptavam aos meios para atingir as metas políticas determinadas. Outra característica é a participação do corpo burocrático no processo de retroalimentação, visto que esses oferecem e inserem soluções no decorrer da implementação e, subsequentemente, "os tomadores de decisão legitimam as práticas já experimentadas" (Secchi, 2010, p. 61).

O debate entre modelos anteriores resultou na produção de recentes instrumentos de pesquisa sobre implementação como a teoria dos jogos e agente principal (Howlett \& Ramesh \& Perl, 2013). Este trabalho não pretende apresentar modelos contemporâneos do estágio de implementação e nem adotar algum, visto que seus objetivos se concentram em aspectos relacionados à tomada de decisão. Sobre este estágio da política pública, muito já foi abordado pela literatura que fundamenta este estudo (Camões, 2013; Côrtes, 2016, Araújo, 2018; Camões \& Meneses, 2016).

\subsection{Considerações teóricas}

Para melhor compreensão do fenômeno da inserção estratégica da área de gestão de pessoas foram abordados os campos científicos da Gestão Estratégica de Pessoas e das Políticas Públicas, sobretudo relevantes variáveis e faces representativas da inserção no ambiente organizacional. No discorrer destes dois campos, foram apresentados estudos oriundos de análises do setor privado e público. Diante das duas literaturas apresentadas, cabe retratar alguns aspectos pertinentes ao objeto analisado.

Ao abordar os dois campos de estudo e suas perspectivas sobre os diferentes elementos do fenômeno, percebe-se algumas paridades e complementaridade que explicam as faces da inserção. A habilidade política da liderança do setor de GP, descrito por Araújo (2018) e Côrtes (2016), transparece como elemento central para compreensão da inserção estratégica, pois a "realização de parcerias" (Castro, 2018) - como iniciativa para mitigação das contingências, se dá através da expertise do representante da área de GP na formação de alianças.

A forma como o líder de GP constrói parcerias pode ser explanada pelo estudo de Rua (2014) ao tratar do jogo político e comportamento dos atores dentro das arenas decisórias, 
sobretudo na dinâmica das relações como lutas, jogos, debates e persuasão. A conexão dos campos torna-se mais clara a medida que o processo de tomada de decisão é elemento inato ao fenômeno da inserção. Assim como os tipos de política (Distributiva, Redistributiva, Regulatória e Constitucional) de Lowi (1964) demonstram ser uma importante variável/indicador ao comportamento dos atores, Forester (1984) também retrata que a definição do problema (problem) é variável influente ao estágio da tomada de decisão. Á vista disso, converge-se que o conteúdo da política discutida nas arenas define o comportamento dos atores justamente por estes terem múltiplas interpretações sobre o problema/política discutido.

Fato a existência destas múltiplas interpretações do problema, que os líderes de GP através de suas habilidades políticas, podem gerenciar o compartilhamento de ideias e soluções nas arenas decisórias em vista a influenciar o comportamento dos atores. O que se deve enfatizar deste diálogo entre os dois campos científicos abordados é que - enquanto Forester (1984, p. 25) aborda a importância da análise situacional do tomador de decisão como "essencial para a escolha e direcionamento da ação para a situação", Sheehan \& De Cieri \& Cooper (2015) traduzem isto como habilidades de interpretar pessoas e situações no trabalho para traduzir este conhecimento em objetivos direcionados para influenciar outros, ou seja; os dois campos comprovam que a habilidade política da liderança de GP é fator primordial para a inserção estratégica da área de GP nas arenas decisórias.

Outro ponto de convergência que revela preciosos detalhes sobre o fenômeno, tal qual aprofunda a conexão com a habilidade política, é a relação entre a "Realização de parcerias" (Castro, 2018), “As ações formais e informais da área de GP” (Sheehan, 2005), o comportamento dos atores na arena de Rua (2014) e os estilos de tomada de decisão de Forester (1984). Dois estilos são os que mais se assemelham ao que retrata a literatura de GEP.

A estratégica do estilo de sondagem (Social Intelligence Networks) é a busca por redes de contatos, ou seja, a realização de parcerias demostra ser uma estratégica comum aos tomadores de decisão e - conforme Forester (1984), utilizar de conhecimento técnico para angariar alianças é uma possível prática a ser usada pelos atores. Rua (2014) converge e aprofunda a discussão, à medida que retrata a utilização do domínio técnico dos atores sobre o conteúdo da política no intuito de convencer (persuasão) os adversários da melhor argumentação e transformá-los em aliados. Porém, quando a persuasão não resulta no triunfo da formação de alianças, Rua (2014) detalha outros comportamentos prováveis - intercâmbios, ameaças, coalizões e exercício da autoridade direta e indireta; para a obtenção de parcerias. 
Outro estilo de tomada de decisão relacionada a iniciativa descoberta por Castro (2018) é o estilo barganha (bargain ou increment), pois além da multiplicidade de definições do problema/política relatada por este, Forester (1984) afirma que a principal estratégia dos atores é a manipulação, distorção e contestação das informações para incrementar suas ideias à política discutida - à medida que conquistam aliados na arena decisória. Além dos comportamentos já abordados de Rua (2014), Sheehan (2015) e Buyens \& De Vos (2001) convergem a discussão ao retratar que o representante e unidade de GP - através dos meios formais ou informais, apresentam os benefícios de cada política, controlam a percepção das informações e manipulam as impressões dos demais atores sobre os valores das iniciativas da GEP.

O comportamento do representante da unidade de gestão de pessoas frente às informações/conteúdo da política discutida reflete o nível de envolvimento do setor no processo de tomada de decisão. Uma "GP orientada para o valor" (setor reconhecido como parceiro estratégico) ou "envolvimento oportuno da GP” (setor ativo na criação de instrumentos e suporte para implementação de políticas) representam não só a percepção da organização sobre a unidade de gestão de pessoas, mas principalmente o quanto as informações produzidas pelo setor de GP são relevantes e essenciais para a organização e principais atores decisórios. Estas informações podem subsidiar à escolha das principais soluções no processo decisório, assim como o gestor de GP pode ser convocado a envolver-se na arena. A credibilidade dada às informações produzidas pelo setor de GP, traduz-se como face da "Reputação da unidade de GP” de Côrtes (2016) - pois, são os juízos de valor provenientes dos membros da cúpula "acerca de suas expectativas quanto à qualidade dos serviços fornecidos pela unidade de GP” (Côrtes, 2016, p. 41).

Enquanto o campo científico da Gestão Estratégica de Pessoas contribui com uma análise da unidade de GP frente aos desafios organizacionais - sobretudo o comportamento do representante do setor no processo decisório, a literatura de Políticas Públicas enriquece a discussão ao abordar as complexas inter-relações que ocorrem nas arenas, assim como o funcionamento do jogo político entre atores na administração pública. O que se deve ter em vista é a forte conexão das habilidades políticas do representante de GP com a inserção estratégica, pois os elementos anteriores retratam quais comportamentos são comumente utilizados pelo gestor de GP na arena decisória (persuasão e manipulação das informações), não excluindo a possibilidade de outros (coalizão, ameaças ou exercício da autoridade direta ou indireta). Contudo, assim como o representante de GP pode utilizar destes comportamentos para exercer influência, este também sofre do exercício político dos demais atores decisórios. Este 
impacto dos atores políticos sobre os gestores de GP traduz-se na "Configuração Política da Organização" de Côrtes (2016), por destacar a divergência das agendas dos atores políticos com os gestores da organização (Ingraham \& Rubaii-Barrett, 2007), ou mudanças de prioridade nas atividades de GP por causa do ambiente político.

Os dois campos científicos também convergem ao apresentar soluções tanto para a contingência da inserção estratégica da unidade de gestão de pessoas, quanto para os prejudiciais comportamentos políticos enraizados desde à formação da administração pública brasileira (Lima, 1998; Costa, 2008; Cavalvante, 2017). Ao tecer a relação das iniciativas organizacionais com os fatores interferentes nas políticas de GEP, o modelo de Araújo (2018) ressalta a criação de uma unidade de governança de pessoas central, ou seja, uma estrutura formal de acesso do setor de GP ao processo decisório que - consequentemente, instigaria o desenvolvimento das habilidades políticas da liderança da unidade. Cavalcante (2017) descreveu esta mesma iniciativa, à medida que ele aponta uma atual transição colaborativa do setor público para ampliação da cooperação entre atores nos processos decisórios (governança) - portanto, a ampliação do relacionamento dos diversos atores pode resultar no combate aos comportamentos políticos prejudiciais à implementação das políticas de GEP.

A construção de mecanismos de participação democráticos e deliberativos que Cavalcante (2017) disserta, assemelha-se ao que Castro (2018) trata sobre a "realização de parcerias". Porém, enquanto o primeiro tem por objetivo a institucionalização de uma nova arena decisória formal, o segundo representa a tentativa desta formalização pelos representantes e unidades de GP a partir de meios informais. O que se deve salientar é a possibilidade da unidade de gestão de pessoas fomentar a construção de novas estruturas decisórias descentralizadas. Ao tratar de políticas constitucionais - que contém caráter estruturador, modificam instituições e processos de negociação; Rua (2014) retrata sobre a possibilidade de reestruturação, assim como Forester $(1984$, p. 28) relata a necessidade dos tomadores de decisão adotarem estratégias (Organizacional, Antecipate ou Democratize) "que trabalham na direção para igualdade efetiva, participação e voz", ou seja, comportamentos que objetivarão a alternância das estruturas de poder.

A incitação da unidade de GP pela confecção ou reconfiguração de novas arenas representa uma face do fenômeno da inserção estratégica, visto que - a partir das habilidades políticas, o representante de GP pode moldar seu comportamento no intuito de obter alianças com atores estratégicos que patrocinem seu acesso formal às arenas decisórias reconfiguradas. 
Como último ponto de relato das considerações teóricas, a habilidade política de GP dentro das relações já feitas, impacta diretamente no "Papel da unidade de GP na implementação das estratégias organizacionais" e na "Coexistência funcional de GP" (Côrtes, 2016; Castro, 2018; Araújo, 2018). Devido ao gerenciamento das expectativas dos atores organizacionais - o que recobra a unidade de GP estar atenta a diversidade real de seus papéis (Sheehan \& De Cieri \& Cooper \& Shea, 2016; Buyens \& De Vos, 2001), quanto mais as habilidades políticas do representante da unidade serem desenvolvidas, possivelmente o acesso às arenas e processos decisórios aumentará e, por fim, mais papeis estratégicos o setor receberá.

Porém, pode-se deduzir o contrário: a "Coexistência funcional de GP” pode servir como indicador da inserção estratégica - pois, se o setor de GP despende mais tempo na execução de atividades operacionais, consequentemente este reduz "a possibilidade de despender esforços em ações de maior valor estratégico" (Araújo, 2018, p. 28). Neste caso, pela não presença nas arenas decisórias, as habilidades políticas do representante de GP poderão ser atrofiadas.

Sem ser redundante, retoma-se o conceito que: a participação da unidade de Gestão de Pessoas nas principais arenas decisórias para o alinhamento entre alta administração sobre as políticas e práticas de Gestão Estratégica de Pessoas, assim como incrementos no planejamento estratégico, corresponde a categoria da inserção estratégica das áreas de GP (Araújo, 2018). Nítido é o elemento da habilidade política da liderança de GP como fator primordial para a descrição e compreensão do processo de inserção estratégica. A partir da análise dos comportamentos políticos da liderança de GP - no intuito de obter alianças, sobre as informações/conteúdo da política discutida na arena, a inserção de novas ideias/soluções dentro e fora da arena e a proposição/fomento de uma nova estrutura decisória que abarque o setor de GP; é possível descrever a forma como o setor de gestão de pessoas garante acesso formal aos principais espaços decisórios organizacionais. 


\section{Métodos e Técnicas de Pesquisa}

Esta seção tem por objetivo descrever os métodos e técnicas de pesquisa que serão empregados neste trabalho para cumprimento dos objetivos. A Tabela 6 sumariza os procedimentos metodológicas da pesquisa.

Tabela 6 Especificação dos procedimentos metodológicos da pesquisa

\begin{tabular}{|c|c|}
\hline Tipo & Teórico-empírica \\
\hline Natureza & Descritiva \\
\hline Abordagem & Qualitativa \\
\hline Escopo & Unidades de Gestão de Pessoas \\
\hline Recorte temporal & Transversal com características longitudinais \\
\hline \multirow{3}{*}{ Objetivos específicos } & $\begin{array}{l}\text { i) Identificar os conteúdos das políticas abordadas } \\
\text { pela área de GP nas arenas decisórias }\end{array}$ \\
\hline & $\begin{array}{l}\text { ii) Identificar quais fatores facilitam ou dificultam a } \\
\text { inserção estratégica da unidade de GP }\end{array}$ \\
\hline & $\begin{array}{l}\text { iii) Identificar quais as habilidades políticas mais } \\
\text { utilizadas pelo líder de GP para acesso às arenas } \\
\text { decisórias }\end{array}$ \\
\hline Métodos & Levantamento de opiniões \\
\hline Amostragem & Rígida \\
\hline Amostra & $\begin{array}{l}\text { a) Gestor principal da unidade de GP } \\
\text { b) Gestores secundários da unidade de GP }\end{array}$ \\
\hline Técnicas de coleta & Entrevista semiestruturada \\
\hline
\end{tabular}




\begin{tabular}{|c|c|}
\hline Instrumento & Roteiro de entrevista \\
\hline Análise dos dados & Análise de conteúdo pré-categórica \\
\hline
\end{tabular}

Fonte: Elaborado pelo autor

Devido as informações serem coletadas em campo, no objetivo de descrever o processo de inserção estratégica da área de Gestão de Pessoas de duas organizações públicas e seus profissionais nas arenas decisórias, a pesquisa é de tipo teórico-empírico. Sua natureza é descritiva, pois procura a "descrição das características de determinada população ou fenômeno ou o estabelecimento de relações entre variáveis" (Gil, 2008, p. 28).

A abordagem deste trabalho é qualitativa, visto que busca tratar o nível de determinada realidade que não pode ser quantificado e que busca trabalhar com o universo de significados nos espaços mais profundos das "relações, dos processos e dos fenômenos" (Minayo, 2012, p. 22). Portanto, o caráter qualitativo oferecerá melhor entendimento sobre o ambiente complexo de múltiplas relações interpessoais que circunda as arenas políticas que, consequentemente, influenciam o fenômeno da inserção.

Pela inserção estratégica não ser considerada um fenômeno estático, que varia a cada mudança representativa em organizações públicas, o recorte temporal é caracterizado como transversal com características longitudinais; pois os dados serão coletados em um único ponto no tempo - mas estes representam períodos atuais e anteriores (Flick, 2009; Creswell, 2007).

Na finalidade de alcançar os objetivos específicos do trabalho, que resultaram atingir a proposta deste estudo, o levantamento qualitativo de opiniões foi preferido como método de condução. Justifica-se a escolha devido o procedimento - que foi por meio de entrevistas semiestruturadas, representar a procura por memórias, experiências e opiniões dos indivíduos entrevistados sobre o assunto analisado (Cooper \& Schindler, 2016; Minayo, 2012). 


\subsection{Amostragem}

Para dar prosseguimento ao estudo, a seleção de amostra adequada seguiu duas camadas: (i) a escolha da organização pública para a pesquisa e (ii) os participantes que foram entrevistados.

\subsubsection{Caracterização da organização abordada}

Foram selecionadas duas relevantes organizações da administração pública federal. Foi mantido o sigilo tanto da organização, quanto dos entrevistados. Portanto, apresenta-se informações relevantes para o estudo sobre as duas organizações, que são denominadas de organização “A” e organização "B”.

A primeira organização - “A”, contém a Presidência como instância máxima superior, assim como uma Diretoria Geral (DG) responsável pela condução estratégica de todo o aparato administrativo do órgão. Subordinada ao DG, a unidade de Gestão de Pessoas de "A" tem as seguintes atribuições: planejar, orientar, coordenar, acompanhar e avaliar as atividades inerentes à gestão de pessoas e à gestão do programa de assistência à saúde dos servidores e seus dependentes; gerenciar os sistemas de gestão de pessoas e assegurar a atualização das bases de dados relativas a pessoal e ao controle da estrutura funcional; etc.

A organização "B” contém em sua estrutura administrativa uma Diretoria Geral (DG) responsável por todo o aparato administrativo do órgão. A DG é subordinada à unidade superior colegiada, responsável pela atividade fim do órgão. A unidade de gestão de pessoas é subordinada a DG e tem por atribuições planejar, supervisionar, coordenar e dirigir as atividades de formulação de políticas e a administração de pessoal, seja ativo ou inativo; formular, propor, coordenar e apoiar planos, programas, projetos e ações relacionadas ao planejamento e desenvolvimento de recursos humanos; propor diretrizes para recrutamento, seleção e dimensionamento da força de trabalho; realizar pesquisa de clima organizacional e etc. 


\subsubsection{Amostragem de participantes}

Para ajuste ao estudo, a escolha da amostra foi do tipo rígida - ou seja, procedimentos de seleção pré-determinados e reconhecidos (Flick, 2009); pois a amostra será constituída a partir da comunicação com a principal unidade de GP das organizações pesquisadas. A partir do contato formal com a unidade de Gestão de Pessoas das organizações " $A$ " e "B" que, mediante entrevista e apresentação do projeto de pesquisa, foi investigado quais são os representantes que contêm vínculo direto ou indireto com as arenas decisórias; tal qual de que forma a diretoria administrativa hierarquicamente superior a unidade de GP está vinculada às arenas.

Por intermédio do contato com a secretaria, a amostra foi delimitada nos principais gestores de GP com acesso ou não às principais arenas decisórias, ou seja, estruturas formais onde ocorrem o processo decisório e resultam em novas diretrizes políticas para todo o sistema administrativo. Estes participaram das pesquisas no cunho de que as características e fatos do fenômeno foram esclarecidos por suas perspectivas, portanto, permitindo contrastar ou acrescentar os relatos prestados por cada participante.

Ao todo foram realizadas três entrevistas individuais com os gestores da unidade de Gestão de Pessoas de suas organizações, sendo um entrevistado na organização "A” e dois na organização "B”. Cabe destacar que, na organização “A”, o entrevistado não é o gestor máximo de GP, porém é um dos representantes da unidade. Na organização "B" foram realizas entrevistas com o principal representante e outro gestor subordinado. $\mathrm{O}$ entrevistado de " $\mathrm{A}$ " está a mais de um ano no cargo, enquanto os entrevistados de "B" contém três e seis, respectivamente, meses de ocupação dentro do setor de gestão de pessoas.

\subsection{Instrumento de coleta dos dados}

O uso da entrevista semiestruturada como instrumento de coleta se justifica na sua adequação para obter informações acerca dos atores e interações sociais - comportamento humano (Gil, 2008; Cresswell, 2007), na arena política possibilitando identificar e prescrever o fenômeno da inserção estratégica da área de GP por meio de sua manifestação na tomada de decisão organizacional. Novamente os principais entrevistados foram membros das arenas decisórias e representantes da unidade de gestão de pessoas. 
A partir do roteiro semiestruturado (Apêndice A), foram realizadas entrevistas de pergunta aberta em seções - ou pautas, correlacionadas para que o entrevistado tivesse liberdade de discorrer livremente sobre o assunto, assim como o pesquisador pode intervir no propósito de direcionar a pauta; desta maneira proporcionando o alcance dos objetivos da pesquisa (Gil, 2008). As perguntas aplicadas foram destinadas aos dois grupos de participantes.

O roteiro de pesquisa foi construído com base em perguntas que possibilitem a identificação e descrição de características do fenômeno em estudo, ou seja, comportamentos políticos dos líderes de GP e membros das arenas decisórias sobre as informações/conteúdo das políticas de GP, proposição de soluções/ideias dentro e fora das arenas decisórias e fomento a construção de nova estrutura decisória. Portanto, o roteiro objetiva capturar a percepção dos participantes sobre o fenômeno, assim como comparação destas com a literatura disponível.

O roteiro contém três seções que visaram cumprir os objetivos deste trabalho, contudo, as perguntas não foram alocadas em cada seção para capturar os objetivos específicos (i, ii, iii e iv) separadamente. Devido à complexidade do fenômeno e a inter-relação deste com as habilidades políticas, há questionamentos que se referem à mais de um objetivo específico. As três seções são abertas, onde os entrevistados relatam livremente.

\subsection{Coleta e análise dos dados}

As entrevistas foram realizadas presencialmente e houve gravação para análise futura, para isso foi entregue um termo de consentimento (Apêndice $C$ ) aos entrevistados no objetivo de autorizar as gravações e uso dos dados para a pesquisa, desde que respeitado o sigilo. Para que houvesse busca completa das informações teóricas, as entrevistas foram realizadas dentro do período de um mês. Também foi remetido uma carta de apresentação da pesquisa (Apêndice B) às organizações selecionadas com as principais informações do estudo e pedido de agendamento, na finalidade de estabelecer contato inicial com a organização e entrevistados (Gil, 2008).

Utilizado para analisar materiais de texto advindos de qualquer origem, inclusive dados de entrevistas, e descrever sistematicamente as características principais e formais das mensagens dentro de seu contexto social (Flick, 2009; Gil, 2008; Bardin, 1977; Bauer, 2002); a análise de conteúdo foi o método para tratamento e análise dos dados deste trabalho. 
Após o período de coleta das entrevistas semiestruturadas, a análise do conteúdo prosseguiu por três etapas. Na pré-análise (i) - com o objetivo de operacionalizar e sistematizar as ideias iniciais (Bardin, 1977), as entrevistas gravadas foram transcritas e informações referentes a amostra codificadas. A segunda etapa, exploração do material (ii), é caracterizada pelo tratamento dos dados e sua categorização. Após a transcrição, os dados foram submetidos a categorização temática - que consiste classificar o conteúdo da transcrição em elementos temáticos correlacionados ao que aborda a literatura do objeto a ser investigado (Bardin, 1977). Para as perguntas das três seções do roteiro de pesquisa, a análise do conteúdo foi póscategórica. Na terceira e última etapa (iii) - para cumprir com os objetivos deste trabalho, inferências e interpretações dos resultados da análise dos dois grupos da amostra foram realizados.

Após a transcrição de todos os áudios das entrevistas individuais, realizou-se uma análise pré-categórica em que se procurou atender as regras para definição das categorias de Bardin (1977), representadas na Tabela 7.

\section{Tabela 7 Regras para a categorização na análise de conteúdo}

\begin{tabular}{c|c}
\hline Regra & Significado \\
\hline Exclusão mútua & $\begin{array}{r}\text { Cada elemento ou trecho não pode existir em mais de uma divisão ou estarem } \\
\text { classificados em mais de uma categoria }\end{array}$ \\
\hline Homogeneidade & $\begin{array}{r}\text { Um único princípio ou uma única forma de classificação deve nortear o } \\
\text { trabalho, a exemplo de adotar o tema como critério }\end{array}$ \\
\hline Pertinência & $\begin{array}{r}\text { O sistema de categorias deve refletir e estar compatível com o intuito da } \\
\text { pesquisa, com as teorias de fundo e com o objetivo do pesquisador }\end{array}$ \\
\hline Objetividade & $\begin{array}{c}\text { Os critérios de categorização devem ser claros, de forma que a entrada dos } \\
\text { elementos em uma categoria não tenha subjetividade e possa ser corroborada } \\
\text { por outros que não o analista }\end{array}$ \\
\hline Produtividade & $\begin{array}{c}\text { Um conjunto de categorias deve fornecer resultados férteis e úteis à pesquisa, } \\
\text { sendo passíveis de se trabalhar junto com o referencial teórico adotado }\end{array}$ \\
\hline
\end{tabular}

Fonte: elaborada pelo autor com base em Bardin, L. (1977)

Durante análise dos dados transcritos, categorias provenientes de pesquisas anteriores (Côrtes, 2016; Araújo, 2018) - da literatura que abarca este estudo, foram reutilizadas. Por fim, a análise de conteúdo como método para o tratamento dos dados propiciou esclarecimentos sobre o fenômeno da inserção estratégica da área de gestão de pessoas pois - conforme Bardin (1977, p. 133) a "análise de conteúdo fornece informações suplementares ao leitor crítico de uma mensagem". Pelo objeto de estudo e o ambiente da administração pública serem 
constituídos de natureza política cabe, portanto, utilizar de métodos que captem as particularidades existentes das inter-relações dos atores nas arenas decisórias. 


\section{Resultados e Discussão}

A presente seção tem intuito de apresentar os resultados desta pesquisa, assim como cumprir com os objetivos específicos e geral deste trabalho. Na finalidade de apresentação estruturada dos resultados, é apresentada a seguinte estrutura: primeiro, foram abordados os conteúdos das políticas abordadas pela área de Gestão de Pessoas nas arenas decisórias e - em subseção posterior, os fatores interferentes que impactam na inserção estratégica de GP. Retratou-se, em nova subseção, quais foram as habilidades políticas mais utilizadas pelos representantes de GP para acesso às arenas expondo uma discussão integrada dos resultados. Por fim na subseção intitulada conclusão, apresenta-se uma discussão integrada de todo argumento científico deste trabalho.

Novamente, no intuito de respeitar o sigilo das organizações e participantes, não foram revelados a qual organização os dados se referem - assim como o cargo que ocupavam os entrevistados. Algumas precauções foram tomadas para evitar a possibilidade de identificação dos respondentes e organização, portanto, alguns trechos apresentados tiveram informações ocultadas. Com vistas a capturar de que forma o fenômeno da inserção estratégica se exprime em ambientes distintos, as duas organizações retratadas foram codificadas e apresentadas como organização "A” e organização "B”.

Após a transcrição dos dados, devido a análise de conteúdo das entrevistas ser précategórica, categorias provenientes de pesquisas anteriores (Côrtes, 2016; Araújo, 2018) foram reutilizadas, porém algumas categorias foram criadas com base na literatura para complementar o estudo. A Tabela 8 sumariza as descobertas, bem como a recorrência nas organizações que se verificou cada categoria classificada.

Tabela 8 Categorias identificadas

\begin{tabular}{c|c|c|c}
\hline Categoria & Definições & Recorrência & $\begin{array}{c}\text { Frequência } \\
\text { de citação }\end{array}$ \\
\hline \multirow{2}{*}{$\begin{array}{c}\text { Práticas Específicas } \\
\text { da Gestão da Força } \\
\text { de Trabalho }\end{array}$} & A: 4 & \multirow{2}{*}{7} \\
\cline { 2 - 3 } $\begin{array}{c}\text { Garantia de direitos } \\
\text { dos servidores }\end{array}$ & B: 3 & \multirow{2}{*}{1} \\
\cline { 2 - 2 } & A: 1 & B: 0 &
\end{tabular}




\begin{tabular}{|c|c|c|c|}
\hline \multirow{2}{*}{$\begin{array}{c}\text { Recursos } \\
\text { organizacionais }\end{array}$} & \multirow{2}{*}{$\begin{array}{l}\text { Quantidade e qualidade } \\
\text { dos recursos humanos, } \\
\text { tecnológicos e } \\
\text { financeiros controlados } \\
\text { pela organização }\end{array}$} & A: 3 & \multirow{2}{*}{7} \\
\hline & & B: 4 & \\
\hline \multirow[b]{2}{*}{$\begin{array}{l}\text { Configuração Política } \\
\text { da Organização }\end{array}$} & \multirow{2}{*}{$\begin{array}{l}\text { Padrão de uso das } \\
\text { influências e de } \\
\text { critérios políticos na } \\
\text { formação da agenda da } \\
\text { alta cúpula }\end{array}$} & A: 1 & \multirow[b]{2}{*}{8} \\
\hline & & B: 7 & \\
\hline \multirow{2}{*}{$\begin{array}{l}\text { Habilidade Política } \\
\text { da Liderança de GP }\end{array}$} & \multirow{2}{*}{$\begin{array}{l}\text { Capacidade do } \\
\text { dirigente de GP de } \\
\text { influenciar atores e } \\
\text { grupos de interesse }\end{array}$} & A: 14 & \multirow{2}{*}{16} \\
\hline & & B: 2 & \\
\hline \multirow{2}{*}{$\begin{array}{c}\text { Coexistência do } \\
\text { Papel Funcional de } \\
\text { GP }\end{array}$} & \multirow{2}{*}{$\begin{array}{l}\text { Proporção da divisão } \\
\text { de tempo e esforço da } \\
\text { unidade de GP } \\
\text { dirigidos para suas } \\
\text { atividades funcionais e } \\
\text { estratégicas }\end{array}$} & A: 0 & \multirow[b]{2}{*}{2} \\
\hline & & B: 2 & \\
\hline \multirow{2}{*}{$\begin{array}{c}\text { Recursos da Unidade } \\
\text { de GP }\end{array}$} & \multirow{2}{*}{$\begin{array}{l}\text { Quantidade e qualidade } \\
\text { dos recursos humanos } \\
\text { e materiais controlados } \\
\text { pela unidade de GP }\end{array}$} & $\mathrm{A}: 1$ & \multirow[b]{2}{*}{1} \\
\hline & & B: 0 & \\
\hline
\end{tabular}

Fonte: Elaboração do autor

Segue a apresentação de cada categoria nas seções subsequentes com base nos objetivos específicos desta pesquisa.

\subsection{Conteúdos das políticas abordadas pela área de gestão de pessoas}

No decorrer das entrevistas, perguntas abertas (Apêndice A) foram realizadas no intuito de capturar quais os principais assuntos tratados pela área de gestão de pessoas no ambiente organizacional, sobretudo nas arenas decisórias. A Tabela 9 sumariza os resultados encontrados ao exibir a frequência em que cada categoria foi abordada, isto é, a quantidade de trechos destacados e classificados em cada categoria ao longo da análise, bem com a recorrência nas organizações que se verificou a categoria classificada. 
Tabela 9 Conteúdos das políticas abordadas pela área de GP

\begin{tabular}{c|c|c}
\hline Conteúdo abordado & Recorrência nas organizações & $\begin{array}{c}\text { Frequência de } \\
\text { citação }\end{array}$ \\
\hline \multirow{2}{*}{$\begin{array}{c}\text { Práticas Específicas da Gestão } \\
\text { da Força de Trabalho }\end{array}$} & A: 4 & \multirow{2}{*}{7} \\
\cline { 2 - 2 } & B: 3 & \multirow{2}{*}{1} \\
\hline $\begin{array}{c}\text { Garantia de direitos dos } \\
\text { servidores }\end{array}$ & A: 1 & B: 0 \\
\hline
\end{tabular}

Fonte: Elaborado pelo autor

O conteúdo das políticas abordadas se refere aos assuntos que tanto foram inseridos na pauta de discussão pela área de GP, quanto os principais atores decisórios solicitaram parecer à área. Os entrevistados das duas organizações públicas relataram temas convergentes, ou seja, ambas unidades de GP têm tratado nos diferentes níveis organizacionais o conteúdo "Práticas Específicas da Gestão da força de trabalho".

Segundo os relatos, a cúpula administrativa, gerentes de linha e servidores têm requisitado às unidades de GP soluções referentes à planejamento, formulação, implementação e acompanhamento de soluções/políticas para os problemas de quadro de pessoal. Essas soluções foram exemplificadas por ambas organizações como: implementação da nova política de teletrabalho, abertura de concurso público, automação de processos, contratos de força terceirizada e carga horária de trabalho. Seguem relatos dos entrevistados:

"Certamente o que a gente tem mais enfrentado é necessidade de alocação de pessoas, que no serviço público você não tem uma possibilidade de reposição rápida. Os servidores precisam fazer concurso, então garante que nós não temos feito e o número de pessoas têm diminuído. Você vai alocar, realocar, redistribuir as pessoas e otimizar o uso das pessoas é a principal preocupação do cenário ultimamente. Essa é uma discussão permanente nos níveis decisórios da casa" (Entrevistado 1, organização B)

"A organização é feita de pessoas e, ultimamente, um dos grandes desafios da gestão pública é fazer mais com menos ou pelo menos fazer o mesmo com menos. Porque a gente perde pessoas diariamente de aposentadoria" (Entrevistado 2, organização B)

"Bom, especificamente aqui na organização "A", uma coisa que tem bastante impacto é a questão orçamentária e acho que nos órgãos públicos isso é uma verdade de maneira geral, porque a gente gasta muito com pessoal. Então o que envolve o orçamento - geralmente, ou questões orçamentárias impactam na questão de pessoal ou vice-versa. Às vezes alguma ação, alguma política, uma coisa relacionada a pessoal vai impactar também" (Entrevistado 1, organização A)

"A gente tem um número grande de terceirizados e colaboradores. Isso também é uma coisa que é muito cobrado e que a gente também leva uma via de mão dupla, porque, para você contratar os colaboradores, renovar um contrato desse, a área de gestão de pessoas também tem que fazer uma análise. Tem que se manifestar se é necessário, se já tem um cargo que supre isso ou não. A gente utiliza força terceirizada também como cliente dessas áreas. Eu acho que uma coisa que é muito cobrado é a necessidade de 
pessoal, que é frequentemente trazida pelos gestores que levam ao nível estratégico e muitas vezes retornam isso." (Entrevistado 1, organização A)

"A políticas que está sendo implementadas é de automação de processos, justamente por causa desse cenário de perda de pessoal. Basicamente as políticas que vem são para solucionar esse problema" (Entrevistado 2, organização B).

"Tanto em nível estratégico, o que que acontece por exemplo: Teletrabalho. Foi uma política relativamente recente que foi proposta pela Secretaria de Gestão de Pessoas, mas tanto para ela ser proposta ela já era uma demanda que existia" (Entrevistado 1, organização A)

"Essa questão de horas extras é coisa que sempre acontece. A questão não é na verdade de carga horária. É sempre uma questão, porque a gente tem uma sazonalidade então vai impactar de um jeito ou de outro. Isso sempre é uma coisa que tanto é demandado, quanto é levado. Novamente, hora extra envolve dinheiro" (Entrevistado 1, organização A)

Essa necessidade sobre uma melhor gestão da força de trabalho não é característica exclusivas de ambas organizações. O referencial teórico deste trabalho já retratou as disfunções da gestão estratégica de pessoas no setor público, sobretudo as pesquisas de Moura e Souza (2016) e Marconi (2010) que relatam a ausência de um planejamento da força de trabalho e estrutura de incentivos pautados no cumprimento dos objetivos estratégicos. Também foi ressaltado o uso errôneo de ferramentas de GEP, assim como a forte característica da influência política nos processos de formulação e decisão das políticas de GP. Portanto, esta adversidade da gestão da força de trabalho é uma característica da atual administração pública brasileira.

Além de expor qual o principal conteúdo abordado, a alta frequência da categoria “ Gestão da força de trabalho" em ambas organizações permite - através dos relatos, identificar uma contingência influente para a inserção estratégica de GP. Infere-se que o conteúdo advém de aspecto externo a organização, ou seja, fora de seu controle e que afetam os processos políticos-administrativos internos. Côrtes (2016) intitula esta característica de fator institucional, precisamente "aspectos societais", que compõem "variáveis do ambiente externo decorrentes da estrutura, organização e função da sociedade, que podem impactar indiretamente as organizações e, consequentemente, suas unidades de GP” (Côrtes, 2016, p. 38).

Para a compreensão da inserção estratégica da área de GP, devido o conteúdo da "Gestão da força de trabalho" traduzir-se em "aspecto societal", pode-se inferir que os atores decisórios mais solicitam parecer da área de GP, do que a unidade insere o assunto na pauta de discussão - pois, o conteúdo pertence a agenda política central do governo. A agenda não é exclusiva da alta cúpula das organizações apresentadas. A área de gestão de pessoas pode não obter acesso 
às principais arenas decisórias, se os conteúdos interpostos por ela forem divergentes da agenda central.

Outro conteúdo abordado pela área de GP é a "Garantia de direitos dos servidores". Com baixa frequência e identificado somente na organização "A”, este assunto está relacionado à pressão dos servidores da "A" para que seus diretos - relativos a políticas de pessoal, sejam cumpridos e mantidos.

\begin{abstract}
A gente também tem que sido bem cobrado assim, no caso do lado dos Servidores. Então, os servidores cobram muito a área de gestão de pessoas para fazer coisas por eles, para fazer o direito deles valerem, para conseguir novos direitos, para não perderem coisas; então servidores demandam muito também da área de gestão de pessoas. Não só níveis estratégicos, também o servidor consegue - muitas vezes, chegar no nível estratégico. Por via do estratégico chega de volta na área de gestão de pessoas (Entrevistado 1, organização A)
\end{abstract}

Deste conteúdo merecem dois pontos de destaque. Primeiro, o entrevistado retrata a existência de outro ator influente na arena decisória da "A": os servidores destinatários das políticas de pessoal da organização, ou seja, os destinatários das políticas implementadas (Secchi, 2010). Segundo, devido ao conteúdo estar diretamente relacionado aos servidores, assim como versa sobre seus direitos e normas, esta pressão dos destinatários sobre o setor de GP e nível estratégico era prevista. Rua (2014) retrata que políticas regulatórias contém alta possibilidade de conflito, visto que sua arena é caracterizada pelo embate entre beneficiados e prejudicados - pois, direitos, sanções e regras são estabelecidas para determinar o acesso a recursos.

Por fim, pode-se concluir que a análise do conteúdo abordado pela área de GP permite visualizar quais sãos as principais demandas da área, ou seja, sobre o que e quando as unidades são convocadas para estarem presentes nas arenas decisórias. No roteiro de pesquisa (Apêndice A), direcionar as perguntas abertas relacionando-as ao assunto prioritário da área de GP permitiu, pois, capturar as interações sociais existentes na arena - assim como quais fatores facilitam ou dificultam a inserção do representante de GP nos espaços de discussão.

\title{
4.2 Fatores Interferentes
}


Novamente, o trabalho de definição das categorias tomou como alicerce aquilo que já se encontrava na literatura. As categorias dos fatores interferentes de Côrtes (2016) foram retomadas neste estudo, visto a relação destas com o fenômeno da inserção estratégica. A partir dos relatos dos entrevistados, visando identificar quais fatores facilitam ou dificultam a inserção estratégica da unidade de GP, a Tabela 10 apresenta as categorias encontradas e suas frequências de citações.

\section{Tabela 10 Fatores Interferentes}

\begin{tabular}{|c|c|c|c|c|}
\hline Fatores & Categoria & Definições & Recorrência & $\begin{array}{c}\text { Frequência de } \\
\text { citação }\end{array}$ \\
\hline \multirow[t]{2}{*}{ Organizacionais } & \multirow{2}{*}{$\begin{array}{c}\text { Recursos } \\
\text { organizacionais }\end{array}$} & \multirow{2}{*}{$\begin{array}{l}\text { Quantidade e qualidade } \\
\text { dos recursos humanos, } \\
\text { tecnológicos e } \\
\text { financeiros controlados } \\
\text { pela organização }\end{array}$} & A: 3 & \multirow[t]{2}{*}{ (2) } \\
\hline & & & B: 4 & \\
\hline \multirow{4}{*}{ Políticos } & \multirow{2}{*}{$\begin{array}{l}\text { Configuração Política } \\
\text { da Organização }\end{array}$} & \multirow{2}{*}{$\begin{array}{l}\text { Padrão de uso das } \\
\text { influências e de critérios } \\
\text { políticos na formação da } \\
\text { agenda da alta cúpula }\end{array}$} & A: 1 & \multirow{2}{*}{8} \\
\hline & & & B: 7 & \\
\hline & \multirow{2}{*}{$\begin{array}{l}\text { Habilidade Política da } \\
\text { Liderança de GP }\end{array}$} & \multirow{2}{*}{$\begin{array}{l}\text { Capacidade do dirigente } \\
\text { de GP de influenciar } \\
\text { atores e grupos de } \\
\text { interesse }\end{array}$} & A: 14 & \multirow[t]{2}{*}{16} \\
\hline & & & B: 2 & \\
\hline \multirow{4}{*}{ Setoriais } & \multirow{2}{*}{$\begin{array}{l}\text { Coexistência do Papel } \\
\text { Funcional de GP }\end{array}$} & \multirow{2}{*}{$\begin{array}{l}\text { Proporção da divisão de } \\
\text { tempo e esforço da } \\
\text { unidade de GP dirigidos } \\
\text { para suas atividades } \\
\text { funcionais e estratégicas }\end{array}$} & A: 0 & \multirow{2}{*}{2} \\
\hline & & & B: 2 & \\
\hline & \multirow{2}{*}{$\begin{array}{c}\text { Recursos da Unidade } \\
\text { de GP }\end{array}$} & \multirow{2}{*}{$\begin{array}{l}\text { Quantidade e qualidade } \\
\text { dos recursos humanos e } \\
\text { materiais controlados } \\
\text { pela unidade de GP }\end{array}$} & A: 1 & \multirow{2}{*}{1} \\
\hline & & & B: 0 & \\
\hline
\end{tabular}

Fonte: Elaborado pelo autor

As categorias "Habilidade Política da Liderança de GP" e "Configuração Política da Organização" obtiveram elevado número de citações. Este resultado reafirma o considerável impacto da esfera política sobre os processos político-administrativos da unidade de gestão de pessoas, assim como as habilidades políticas do representante de GP são determinantes para o acesso às arenas decisórias. "Recursos organizacionais" também obteve grande número de citações, os quais convergiram para um tema central nas duas organizações pesquisadas. Por fim, mesmo com baixa frequência, as demais categorias revelam notáveis especificidades que não devem ser descartadas. 
No intuito de retratar todos os fatores interferentes que impactam no fenômeno da inserção estratégica de pessoas, de modo que haja exposição completa com base na literatura, as categorias foram descritas de acordo com a ordem crescente de frequências, ou seja, do menor número de aparições para o maior.

A categoria de menor frequência é "Recursos da unidade de GP" e só foi detectada na organização “A”. Conforme Araújo (2018) e Côrtes (2016), ela trata dos impactos causados pela quantidade e qualidade dos recursos humanos, materiais, orçamentários e financeiros do setor de GP. Durante análise dos dados, foi possível a captura de que o gestor de GP - que conhece a natureza do cargo e as particularidades da organização, tem maior probabilidade de sucesso em suas iniciativas. Segue o relato.

\footnotetext{
"Hoje o nosso gestor é uma pessoa bem eloquente. Ele é antigo do tribunal, então conhece muita gente e aqui na "A" as coisas funcionam muito na camaradagem, no certo sentido" (Entrevistado 1, organização A)
}

Retoma-se a discussão de Sheehan (2016) dos profissionais de GP terem entendimento claro de como a gestão de pessoas encaixa - e suporta, a missão e estratégia organizacional da mesma maneira em que devem dominar os processos básicos de negócio. Este domínio traduzse no representante de GP reconhecer os pormenores da organização como cultura, os atores, meios formais e informais de comunicação - portanto, utilizando destas informações de modo a agregar seu trabalho. A qualificação do gestor de GP - no quesito de tempo no cargo, é um elemento influente para a inserção estratégica da área de GP.

Pela ordem de frequência, a segunda categoria de menor aparição é "Coexistência do Papel Funcional de GP”. Esta só foi detectada duas vezes na organização "B”. Sobre a "Coexistência do Papel Funcional de GP”, no decorrer dos relatos foi possível perceber que a organização "B" prioriza a alocação de seu esforço em atividades operacionais, dispensando as estratégicas. Conforme abordado por Araújo (2018, p. 28), a unidade de GP que consome mais tempo em tarefas operacionais reduz "a possibilidade de despender esforços em ações de maior valor estratégico". Consequentemente, a unidade de GP terá menos oportunidade de se inserir na arena decisória e ser reconhecida como parceira estratégica ou "GP orientada para o valor" de Buyens \& De vos (2001). Seguem os relatos:

\footnotetext{
"A gente não tem muitas outras preocupações grandes, ou grandes políticas estratégicas de pessoal, porque a gente tá tendo que apagar incêndio de falta de pessoal. Então, quando você apaga incêndio, você não pensa em grandes reformulações ou mudanças de estrutura" (Entrevistado 2, organização B)
} 
"No concurso tem a área de contratações, advocacia, a Secretaria Geral da mesa. Precisa englobar o órgão como um todo e raramente alguma política nasce aqui e é decidida daqui. Sempre a advocacia participa. A diretoria-geral sempre, a gente é subordinado a ela. A gente não toma nenhuma política por iniciativa própria. A não ser no nível operacional mesmo. Mas alguma reformulação, nada é feito sem o aval da diretoria geral" (Entrevistado 2, organização B)

Os relatos demonstram a realidade da organização "B" e sua primazia em demandas emergenciais e atividades operacionais, não restando tempo para o debruçar em questões estratégicas. A literatura ressalta a importância de o representante da unidade de gestão de pessoas estar atento ao gerenciamento das expectativas dos atores organizacionais, além da diversidade real dos papéis da área (Sheehan \& De Cieri \& Cooper \& Shea, 2016; Buyens \& De Vos, 2001). Se a unidade de GP é vista pela organização somente como setor operacional significa que: ou o setor e representante tomaram posse desta característica, ou ambos têm dificuldade para definir suas atribuições (Sheehan \& De Cieri \& Cooper \& Shea, 2016).

A próxima categoria na ordem crescente de aparições diz respeito a quantidade e qualidade dos recursos tecnológicos, humanos e financeiros de controle pela organização (Côrtes, 2016). "Recursos organizacionais" foi identificada sete vezes, porém, todos os relatos convergiram para o impacto da qualificação dos gestores da organização sobre os processos políticos-administrativos. Nos relatos, a palavra "visão sistêmica" favoreceu a identificação e compreensão do impacto da categoria.

Os entrevistados de ambas organizações relataram uma frequente dificuldade que os gestores, seja de linha/intermediários ou da alta cúpula administrativa, têm de compreenderem as especificidades de cada setor da organização e de que forma cada específico impacta no todo. "Acredito que sim. Acho que é uma questão também das pessoas terem tempo, de
terem uma valorização disso, de terem uma valorização do trabalho do outro, de você
ter essa visão sistêmica" (Entrevistado 1, organização A)

"Então você tem pessoas que são os gestores maiores da casa como X, secretário-geral da presidência etc. Nem sempre é assim, mas frequentemente são pessoas da área do direito que trabalharam fazendo análise processual a vida inteira. Então eles não têm muito essas vivências e não acreditam muito nessa visão sistêmica das coisas etc. Mais hierarquizado que afeta todos" (Entrevistado 1, organização A)

"De maneira geral a área de pessoas daqui tem um olhar bem sistêmico. Então é uma área que os gestores aqui (alta gestão da secretaria) geralmente procuram inclusive buscar esse tipo de informação para complementar. Politicamente é muito importante. Então sim. Eu acho que nós somos uma esponjinha. A gente está sempre tentando absorver informações."(Entrevistado 1, organização A)

"Gerir as pessoas na verdade não é só da área de gestão de pessoas. Todo gestor é um gestor de pessoas e é preciso trabalhar em conjunto. Então essa visão sistêmica do tema está presente na organização B sim" (Entrevistado 1, organização B)

"Sim. É isso. Ter essa visão muito sistêmica. É preciso alinhar sempre as informações" (Entrevistado 1, organização B) 


\begin{abstract}
"Você não tem uma unidade de visão na Organização B (Entrevistado 1, organização B)"

"Quando a gente discute muitas vezes sobre alocação de mão de obra é óbvio. Há uma tendência de que as pessoas acham que estão sobrecarregadas e de que precisam de mais gente. Esse é um debate que você precisa administrar recursos que são, normalmente, escassos. E aí tem que juntar as diferentes visões para ter uma visão do todo" (Entrevistado 1, organização B)
\end{abstract}

Através dos relatos, é possível perceber a dificuldade que os gestores têm durante o exercício de análise dos macro impactos que uma determinada decisão pode tomar. Outro aspecto é o diferencial que a unidade de GP, sobretudo o representante, tem no desempenho desta tarefa, pois o setor está em constante contato com diferentes áreas organizacionais. A qualificação dos gestores, para o exercício de visão sistêmica necessária à organização, relaciona-se com os constructos que fundamentaram a gestão estratégica de pessoas. É a partir do alinhamento vertical e horizontal ao qual a GEP se propõe, que a unidade de gestão de pessoas não só alcança os objetivos de negócio, mas consequentemente promovem mudanças na geração de bom desempenho, influência na cultura organizacional e conversão do pensamento setorizado dos gestores para uma visão integrada (Buyens \& De Vos, 2001; Ingraham \& Rubaii-Barret, 2007; Araújo, 2018; Camões, 2013; Camões \& Meneses, 2016). Por fim, a unidade de GP tem a oportunidade de fomentar uma cultura de visão sistêmica nos gestores, ao apresentar suas iniciativas.

Para fins de compreensão da inserção estratégica da área de GP, a qualificação dos gestores de diferentes níveis organizacionais tem impacto significativo no acesso da unidade de GP à arena decisória - porém, a influência deste aspecto tanto pode ser um empecilho para a inserção, quanto uma oportunidade. Para a introdução de iniciativas na arena pela unidade de GP, os gestores de GP devem considerar a lacuna do conhecimento sistêmico dos atores. Portanto, o plano de apresentação de suas iniciativas deve conter informações suficientes para que os atores compreendam os macros impactos da Gestão Estratégica de Pessoas.

A categoria "Configuração política da organização" teve elevado número de citações. Os relatos dos entrevistados evidenciam o quanto a unidade e líder de GP são suscetíveis a influências políticas. Novamente pode-se ressaltar o constante comportamento dos atores decisórios em priorizar aspectos políticos, de interesses por vezes ocultos, no lugar de aspectos técnicos. No decorrer deste trabalho, tomou destaque o impacto deste prejudicial comportamento dos atores decisórios. Não só para a unidade de gestão de pessoas - mas 
sobretudo para administração pública brasileira (Costa, 2008; Dias \& Matos, 2012; Secchi, 2010; Côrtes, 2016; Araújo, 2018). Seguem os relatos.

\begin{abstract}
"Então o que a Secretaria de Gestão de Pessoas fez foi colocar num formato de normas de procedimentos, e quando ela sobe - porque toda política aqui vai para ser aprovado pelo nível estratégico (muitas vezes sobe até a presidência, a depender do tipo até para o plenário), então ali também sofre alterações. Porque quem tá nesse degrau aí no topo da hierarquia, muitas vezes tem servidores que têm suas agendas. Influenciam isso. Então, não raro, embora a proposição geralmente venha da secretaria de pessoas alterações são feitas lá no nível estratégico. É bem comum" (Entrevistado 1, organização A)
\end{abstract}

"Fatores políticos, orçamentários, prioridades. Tivemos uma política de gratificação de desempenho (de avaliação de desempenho) que já estava toda regulamentada, e por vontade política/orçamento não foi implementada e todo o trabalho ficou parado. Perdido" (Entrevistado 2, organização B)

"Eu não sei quando é político, que é fora da área administrativa. A gente consegue manejar, discutir, contrapor. Não sendo ordens superiores, é tudo muito bem conversado "(Entrevistado 2, organização B)

"Prototipa, testa e apresenta os resultados para ver se aquilo vira uma política ou não. Se aquilo não é interessante, não é prioritário para a organização" (Entrevistado 2, organização B)

"Respeitando as diretrizes estabelecidas pelos titulares dos cargos e caminhando com prazos tranquilos, para diminuir o impacto disso no auxílio a solução de continuidade" (Entrevistado 1, organização B)

"Que é essa natureza da organização "B" de ele ser sempre colegiado e formado por seus titulares, que têm diferentes visões" (Entrevistado 1, organização B)

"Você tem uma diversidade que é da natureza democrática. Cada ator foi escolhido por diferentes agendas, ideologias e etc. então você tem o desafio de fazer uma gestão que atenda a diferentes demandas e demandas que às vezes são contraditórias" (Entrevistado 1, organização B)

"Normalmente as nossas limitações tem a ver com as vezes ausência de orçamento, ausência de pessoal disponível ou - quando você tem uma necessidade de mudança de normas ou legislação, que demandam convencimento daquilo que está acima da capacidade gerencial. Aquilo que está na esfera da decisão política. Aí você precisa de mais tempo para conseguir trabalhar. Mudar uma lei é algo que gastar algum tempo. (...). Essas são as maiores dificuldades da natureza mesmo da administração pública, enquanto você enfrenta à necessidade de modificar normas, que aí precisa acionar um aparelho de Estado mais elaborado para fazer essa mudança" (Entrevistado 1, organização B)

Cabe ressaltar alguns pontos de atenção advindos dos relatos. A categoria da "Configuração política" representa justamente o efeito dos comportamentos dos membros da arena decisória sobre o líder e unidade de GP. Pode-se afirmar que o setor de GP da organização "B" é bastante afetado pela contradição das agendas dos atores decisórios (Ingraham \& RubaiiBarrett, 2007), portanto, gerando embates e dificuldades no atendimento às demandas pela unidade de GP. 
Diferente da organização "B", a categoria de "Configuração política da organização" só foi evidenciada uma única vez na organização "A". Percebe-se a liberdade que a unidade de gestão de pessoas da "A" tem na proposição de soluções, mesmo se essas sofrem alterações pelos membros das arenas. Novamente, a compreensão da atual configuração política da organização auxilia a unidade de gestão de pessoas se posicionar de maneira eficaz contra os comportamentos contraditórios. A forma como o líder de GP se apropria das informações da configuração política - múltiplas agendas de interesse dos atores, e usa ao seu favor, é descrito pela categoria seguinte.

Identificada quatoze vezes na organização "A" e duas na "B", totalizando dezesseis frequências, a categoria "Habilidade Política da Liderança de GP" tem influência direta na inserção estratégica de pessoas. Cabe novamente conceituar as definições de habilidade política, visto a relevância desta. Conforme Sheehan \& De Cieri \& Cooper (2015), as habilidades políticas significam interpretação de pessoas e situações no trabalho para traduzir este conhecimento em objetivos direcionados para influenciar outros. A relevância desta categoria, para a inserção estratégica da área de GP, clarifica-se na análise das inter-relações dos atores dentro das arenas decisórias, ou seja - dentre as dinâmicas de Rua (2014) e estratégias de Forester (1984), quais os recorrentes padrões de comportamento do gestor de GP no decorrer do jogo político.

Na finalidade de cumprir com o terceiro objetivo específico deste trabalho, a próxima seção discorre a respeito das principais habilidades políticas utilizadas pelo líder de GP e seu impacto no acesso às arenas decisórias.

\subsection{Habilidades Políticas dos líderes de GP}

Por meio da análise dos dados coletados, no intuito de capturar essas interações sociais entre o representante de GP e demais atores, com base nas referências da literatura (Forester, 1984; Rua, 2014) - sobretudo Côrtes (2016) e o constructo de política organizacional, foram identificados cinco comportamentos que representam faces da "Habilidade política de GP". A Tabela 11 sumariza as categorias encontradas, assim como suas frequências de citações. As categorias foram descritas de acordo com a ordem crescente de frequências, ou seja, do menor número de aparições para o maior. 
Tabela 11 Habilidades Políticas do Líder de GP

\begin{tabular}{|c|c|c|c|}
\hline Categoria & Definições & Recorrência & $\begin{array}{l}\text { Frequência de } \\
\text { citação }\end{array}$ \\
\hline \multirow{2}{*}{ Persuasão } & \multirow{2}{*}{$\begin{array}{l}\text { Procurar convencer alguém do } \\
\text { seu ponto de vista pelo uso de } \\
\text { argumentações racionais } \\
\text { selecionadas }\end{array}$} & A: 2 & \multirow{2}{*}{$\begin{array}{lllll}3 & & & \\
\end{array}$} \\
\hline & & B: 0 & \\
\hline \multirow{2}{*}{$\begin{array}{l}\text { Produção e } \\
\text { Controle de } \\
\text { Informações }\end{array}$} & \multirow{2}{*}{$\begin{array}{l}\text { Selecionar quais informações } \\
\text { serão distribuídas e quem as } \\
\text { receberá }\end{array}$} & A: 6 & \multirow{2}{*}{7} \\
\hline & & B: 1 & \\
\hline \multirow{2}{*}{ Coalizão } & \multirow{2}{*}{$\begin{array}{l}\text { Aliar-se temporária ou } \\
\text { permanentemente com outros } \\
\text { indivíduos ou grupos para } \\
\text { aumentar o apoio à sua posição } \\
\text { ou para atingir um objetivo } \\
\text { específico }\end{array}$} & A: 2 & \multirow{2}{*}{2} \\
\hline & & B: 0 & \\
\hline \multirow{2}{*}{$\begin{array}{l}\text { Fomento a } \\
\text { Novas } \\
\text { Estruturas } \\
\text { Decisórias }\end{array}$} & \multirow{2}{*}{$\begin{array}{l}\text { Incentivar à construção de novas } \\
\text { estruturas decisórias } \\
\text { descentralizadas }\end{array}$} & A: 1 & \multirow[t]{2}{*}{1} \\
\hline & & B: 0 & \\
\hline \multirow{2}{*}{ Networking } & \multirow{2}{*}{$\begin{array}{l}\text { Aproveitar-se do acesso a } \\
\text { especialistas ou a pessoas que } \\
\text { detêm poder na organização }\end{array}$} & A: 3 & \multirow{2}{*}{4} \\
\hline & & B: 1 & \\
\hline
\end{tabular}

Fonte: Elaborado pelo autor

A categoria "Fomento a novas estruturas decisórias" aborda se os representantes de GP fomentaram, de maneira formal ou informal, a construção de novas arenas/espaços decisórios (Forester, 1984; Rua, 2014; Cavalcante, 2017). O roteiro de pesquisa (Apêndice A) buscou capturar este comportamento. $\mathrm{Na}$ análise dos dados foi possível perceber a presença do comportamento do representante de GP da "A” (uma frequência). Segue o relato.

"Então sim. Eu acho que, nessa gestão o nosso líder de GP, como ele é bem parceiro das áreas de gestão estratégica etc. Ele é uma das áreas, assim, representa a gestão de pessoas e advoga para que a gente tenha espaço desse tipo, arenas desse tipo. A gente assim quer dizer. Pelo menos um espaço de discussão, apresentação das ideias, dos projetos. Ele é uma das pessoas que advoga por isso também" (Entrevistado 1, organização A)

Para a inserção estratégica de GP, o fomento de novas arenas decisórias representa uma tentativa do líder de GP legitimar um novo espaço de discussão que, a priori, terá mais eficiência que o atual, pois visa vencer os déficits da democracia representativa (Cavalcante, 2017). Um novo espaço converge com a iniciativa contra o não acesso às arenas de Araújo (2018): a criação de uma unidade de governança central, ou seja, o representante de GP adota estratégias para “igualdade efetiva, participação e voz” (Forester, 1984, p. 28). 
A categoria "Persuasão" foi identificada duas vezes nos relatos, tendo duas frequências na organização “A”. Conforme Forester (1984) e Rua (2014), é comum atores decisórios utilizarem de conhecimento técnico para angariar alianças. Da mesma forma, o líder de GP da organização "A" evidencia este comportamento. Seguem os relatos.

\begin{abstract}
"E aí é da habilidade do gestor da SGP, naquele momento, de conseguir vender ou não suas ideias. A gente vê que isso faz muita diferença. Quando é uma pessoa articulada, bem colocada, convincente e etc; a gente vê que as nossas políticas avançam bastante. Quando é uma pessoa menos articulada, a gente vê que as políticas de gestão de pessoas ficam mais travadas, conservadoras" (Entrevistado 1, organização A)
\end{abstract}

"Especificamente hoje, a gente tem uma pessoa que ela é muito atuante e muito articulada. Então assim, tem uma oratória muito boa. Ela tem segurança das coisas que ela diz. Preparada tecnicamente também" (Entrevistado 1, organização A)

Foi abordada a existência de múltiplas interpretações dos atores decisórios sobre uma determinada política/problema, assim como o conflito de suas agendas (Configuração Política da Organização) e a consequência da desvalorização de aspectos técnicos. Ao utilizar da persuasão, o representante de GP visa convencer os demais atores de pontos técnicos relevantes para a política discutida, portanto, adquirindo aliados e - consequentemente, sendo reconhecido como autoridade em determinados assuntos e convocado para as arenas.

“Coalizão” é uma categoria definida com base na definição de Rua (2014, p. 25): “Os atores constroem alianças com base em um pequeno ponto de interesse comum, embora permaneçam suas divergências com relação a muitos outros temas". Ou seja, o comportamento referente a criação de acordos ou alianças para atingir mútuos objetivos. Foi evidente a identificação da categoria pelo líder de GP na organização "A” (duas frequências) em que este moldou o seu comportamento, no intuito de colaborar e construir uma aliança para um objetivo comum. Seguem os relatos.

"Por exemplo: área de auditoria e acho que o projeto de dimensionamento da força de trabalho (DFT) é um exemplo ótimo. DFT. Um projeto de DFT é uma coisa que a gente está tentando emplacar já a vários anos aqui, com várias gestões. Nessa gestão teve uma auditoria de força de trabalho realizado no ano de 2018. Era um projeto grande e importante da área de auditoria. Então, embora tenha tido algumas resistências no início, porque ser auditado geralmente nunca é muito agradável. Mas o nosso representante foi muito inteligente em vê que olha 'isso vai acontecer, vamos apoiar o projeto do outro, vamos levantar a bola deles, vamos prestigiar o trabalho que eles estão fazendo'; colaborar. Porque isso depois nos ajudou a fundamentar o DFT, que a gente sabe que é necessário já a bastante tempo, inclusive de uma maneira mais ampla do que a gente tinha imaginado. Então acho que foi muito inteligente da parte dele. Hábil também. Porque não basta só você querer, também conseguiu fazer isso. 
E aí viabilizou uma coisa também que a gente sabia que era necessidade da organização, mas que não tinha ainda um cenário favorável" (Entrevistado 1, organização A)

"Na Parceria, é ligando, é conversando, colaborando também com os projetos das outras áreas, se mostrando disponível. Eu acho que dessa maneira o representante de GP tem conseguido agregar algumas parcerias interessantes" (Entrevistado 1, organização A)

A categoria seguinte de "Habilidades políticas da liderança de GP" obteve quatro frequências. Sheehan (2005) aborda que - se os líderes de GP não dispõem de abertura formal nos espaços decisórios, estes devem se apropriar da informalidade para se envolverem no processo decisório. O "Networking” caracteriza-se pelo sucesso no desenvolvimento, pelo líder GP, de uma rede acessível de comunicação aos principais atores da organização. Evidenciouse a frequência da categoria três vezes na organização "A" e uma na organização "B”. Seguem os relatos.

\footnotetext{
"Numa relação informal, ou uma relação pessoal que você tenha com as pessoas. Não necessariamente pessoal, amigo e tudo. Mais assim: você mandar um memorando para uma área, solicitando alguma coisa, pode não ser tão efetivo quanto (ou ele apenas sozinho não é tão efetivo quando) você também ligar. Você dizer "olha fulaninho". Eu vejo que o nosso líder de GP atua muito assim" (Entrevistado 1, organização A)
}

"Aqui é um lugar muito engessadinho, então ao mesmo tempo uma dificuldade que a gente observa é que aqui há uma necessidade grande de normatizar tudo. E, às vezes, isso engessa um pouco as coisas. Então, às vezes, é até mais interessante você deixar as coisas na informalidade, do que obviamente não é uma estrutura né. Dificulta do que você normatizar, por exemplo, normatizar uma comissão, um grupo de trabalho. Isso te deixa meio preso, numa configuração específica ou algo assim. A gente vai navegando para lá, para cá" (Entrevistado 1, organização A)

"É uma pessoa assim: uma pessoa de pessoas. Ele realmente consegue ter essa coisa agregadora né. De tentar incluir as pessoas, de escutar os outros - então você também tem informações para trocar. Ser colaborativo." (Entrevistado 1, organização A)

"A gente vê quais são os atores que atuam naquela solução que a gente imaginou. Conversar com eles, porque afinal, a gente não vai conseguir implementar sem o apoio deles" (Entrevistado 2, organização B)

O representante de GP que tem uma comunicação acessível com os executivos chave da organização pode se inserir, facilmente, nas principais arenas decisórias de acordo com o vínculo de sua relação com os atores.

A categoria de maior destaque trata sobre de que forma os representantes de GP controlam as percepções das informações e manipulam as impressões dos demais atores sobre as iniciativas de gestão estratégica de pessoas (Sheehan, 2015; Buyens \& De Vos, 2001; Forester, 1984). O "Produção e Controle de Informações" foi o comportamento mais 
evidenciado nos relatos do entrevistado da organização "A" (seis frequências). O líder de GP buscou direcionar o conteúdo para a aliança que ele desejava obter. Seguem os relatos.

\begin{abstract}
"A gente tenta compartilhar pelos meios institucionais. Aí você tem e-mail, você tem Intranet, tem memorando, circular, enfim. Mas também tudo tem uma estratégia, tanto para você compartilhar hierarquicamente acima, quanto para os seus pares. Então a gente tenta ter cuidado com o compartilhamento das informações aqui. Então para você levar para o superior, por exemplo, eu vejo que o nosso representante tem todo um cuidado de 'olha, eu sei que ele necessita de informações desse tipo'. Então existe uma preparação para isso para você já chegar lá preparado. Para o superior máximo também, quando é necessário compartilhar (e muitas vezes é), vender uma ideia para ele. Ser objetivo, ser curto, ter informações que ela considera relevante" (Entrevistado 1, organização A)

"Uma coisa aqui também é bem efetiva é você alcançar os gestores. Então, por exemplo, a secretaria de gestão de pessoas compartilhar essas informações em reunião com os outros secretários. Assim, a gente tentar fazer esse corpo a corpo também. Mas nós temos uma preocupação grande em como essas informações chegam. Não sei se a gente tem sucesso. Mas nada é levianamente liberado aqui, quando é, geralmente gera problema" (Entrevistado 1, organização A)
\end{abstract}

A alta frequência desta categoria permite compreender o impacto da habilidade no processo de inserção estratégica. A principal maneira de enfrentar a multiplicidade de agendas dos atores decisórios (Configuração Política da Organização) é justamente o líder de GP incorporar estas demandas gerais e particulares. A medida que o representante identifica as demandas, as iniciativas que este pretende apresentar na arena serão personalizadas para dialogar com os interesses dos membros. Se houver conformidade das proposições da unidade de GP com a agenda, maior a probabilidade do setor ser convocado a dar seus pareceres portanto, sendo considerado um parceiro estratégico (Buyens \& De Vos, 2001).

Outro fator que revela o quanto a habilidade "Produção e Controle de Informações" garante o sucesso no processo de inserção, são os "Recursos da unidade de GP”. O investimento da unidade na produção de informações relevantes pode resultar na convocação do setor, pois, quanto maior a credibilidade dada às informações produzidas pelo setor de GP, maior a chance de o representante da unidade ser convocado a dar seu parecer na arena decisória. Os relatos dos entrevistados exemplificam estas consequências do alinhamento das agendas pela habilidade "Controle de informações".

"Mas varia um pouco em relação ao tema. Por exemplo: quando é uma coisa sobre dados de pessoal relativo a banco de horas, coisas bem concretas que têm um impacto financeiro orçamentário, que tem um impacto bem direto; sim. São levados à sério. 
(...) Quando é uma coisa mais corriqueira, relacionada a coisas concretas que diretamente impactam o orçamento dinheiro etc; sim. Super levada a sério" (Entrevistado 1, organização A)

"Quando são coisas um pouco mais inovadoras, aí já tem uma certa 'será que gente precisa realmente fazer isso?', 'Porque né? Qual é o nosso ganho?', 'Não vai dar muito trabalho?'. (...). Quando é uma coisa mais inovadora, mais intangível, aí as pessoas já não são tão. Não é que não tenha credibilidade, tem. Mas não tem prioridade, talvez" (Entrevistado 1, organização A)

"Atualmente a gente tem muito essa realidade assim: de surgir um problema e a área de gestão de pessoas, especificamente a gestora, é chamada para considerar sobre este problema e oferecer soluções. Então isso acontece bastante. Assim: um evento da presidência. Em teoria estaria envolvido o cerimonial, não a área de gestão de pessoas. Ela poderia dar um apoio aqui ou ali, mas não. Realmente a gestora foi envolvida em todas as fases do processo. É como se desse uma segurança muitas vezes para o lado estratégico poder ter ali o gestor de pessoas, porque não sei. Uma ideia de que ele pode agregar" (...) "Não é todo gestor de pessoas que é incluído assim, mas atualmente é. " (Entrevistado 1, organização A)

"A gente investiu bastante em gerar melhores informações para tomada de decisão, então hoje, a alta direção da casa tem acesso à bastante jogos de números, indicadores de servidores, perspectivas de aposentadoria, absenteísmo, carência de pessoal, quantidade de horas extras e vários painéis gerenciais; que são fundamentais para dar suporte a essa tomada de decisão e são acessíveis o tempo todo pela direção da casa"

(Entrevistado 1, organização B)

Aos atores decisórios imputarem relevância às informações de GP, significa que os profissionais de gestão de pessoas são reconhecidos como parceiros estratégicos (GP orientada para o valor) e os instrumentos que estes produzem (Envolvimento oportuno da GP) são essenciais para a organização. Buyens \& De Vos (2001) revelam que a unidade de GP está ativamente envolvida nos processos decisórios nestes dois níveis.

De modo geral, as duas organizações pesquisadas contêm díspares níveis de inserção estratégica da unidade de gestão de pessoas. A organização "B" sofre com o excesso de atividades operacionais (Coexistência funcional de GP), assim como os atores decisórios exercem forte impacto nas iniciativas da área (Configuração política da organização). Também não houve fomento de novas arenas pelo líder de GP. Diante deste cenário, as habilidades políticas do líder de GP da "B" apresentaram-se com baixa frequência (duas no total). Duas conclusões são possíveis: primeiro, que o pouco tempo de cargo dos representantes não os possibilitou manifestar as habilidades políticas, pois, não havia domínio da função estratégica de GP e seu impacto sobre os processos básicos de negócio da organização (Sheehan \& De Cieri \& Cooper \& Shea, 2016). Segundo, o não acesso formal à arena decisória resulta no não desenvolvimento das habilidades políticas do líder (Araújo, 2018) - portanto, restando-lhe a inserção estratégica por meios informais. Porém, se o líder de GP da organização "B” não utiliza 
das habilidades (indício da baixa frequência), este terá oportunidades cada vez menores de inclusão no processo de tomada de decisão estratégica (Sheehan, 2015).

A organização "A" evidencia comportamento contrário. Comprovou-se alta frequência de manifestação das habilidades políticas (14 no total), como o elevado uso da habilidade "Produção e Controle de Informações" pelo líder de GP e impacto das informações que a unidade produz, assim como o reflexo do "Tempo de cargo" do representante do setor. Cabe ressaltar o sucesso na rede informal de relacionamento com os executivos chave (Networking), assim como as tentativas de fomentar novos espaços decisórios pelo representante de GP. Estas habilidades evidenciam o esforço do líder de GP em alternar as estruturas decisórias advogando pela necessidade de a unidade de pessoal ser inserida como membro formal e informal (Rua, 2014; Cavalcante, 2017; Forester, 1984) - portanto, ter um canal direto com os principais atores decisórios possibilita inserções contínuas na arena. O setor de GP da organização “A” contém aparente nível de inserção estratégica, conforme indício das categorias - sobretudo a elevada habilidade política do representante.

\subsection{Síntese dos Resultados}

No intuito de retratar os resultados de maneira integrada, cabe uma breve discussão em torno do argumento científico do fenômeno da inserção estratégica da área de pessoas. $\mathrm{Na}$ tentativa de compreender o setor público, nenhuma pesquisa deve ser realizada sem o pesquisador - primeiramente, conectar seu fenômeno de estudo com os aspectos históricos e culturais da administração pública brasileira. Ao não considerar estas características, perde-se detalhes preciosos que demonstram a complexidade da máquina pública.

Conforme o retrato histórico do desenvolvimento da administração pública brasileira, o corpo tecnocrático do Estado se expandiu e adquiriu autonomia graças à grupos de interesses que aderiram a agenda central do governo na época (Costa, 2008; Lima, 1998; Bresser, 1997). Ainda que, em momento inicial, a valorização do capital humano no setor público se deu através de grupos minoritários - é necessário compreender que os burocratas constituem uma importante força política conforme Howlett \& Ramesh \& Perl (2013) relatam. Da mesma forma que grupos de interesse aderiram e exerceram impacto sobre uma agenda central, os atores burocratas - sobretudo representantes da unidade de gestão de pessoas, podem e devem identificar os aspectos societais do momento (fator institucional) e, através de suas 
habilidades políticas, procurar ampliação de sua esfera de influência nos principais espaços de decisão.

Mantém-se o argumento de que as habilidades políticas do líder de GP constituem o principal fator de acesso às arenas decisórias (Araújo, 2018). A partir de uma análise e compreensão dos fatores institucionais, sobretudo aspectos societais (Côrtes 2016), o líder de GP poderá fazer frente às agendas contraditórias dos principais atores (Configuração Política da Organização), pois ele saberá que a agenda dos tomadores de decisão é regida por uma agenda central, externa à organização (Côrtes, 2016; Ingraham \& Rubaii-Barrett, 2007). Sem a identificação dos pontos de convergência entre as agendas, o representante de GP não poderá participar eficazmente do jogo político.

Precisam ser feitas algumas ressalvas sobre os fatores interferentes que impactam na inserção. "Recursos da unidade de GP" (Côrtes, 2016), especificamente o tempo de cargo do gestor de GP, revelou-se um aspecto importante. Pois, além do líder de GP compreender os pormenores da organização em que está inserido, assim como os processos básicos de GEP e do negócio organizacional (Sheehan, 2016); ele deve estar ciente dos aspectos societais e as agendas dos atores decisórios. Porém, devido sua baixa frequência, ele não é o aspecto dominante para a inserção.

A "Coexistência do Papel Funcional de GP” continua sendo uma consequência e também indicador do nível de inserção estratégica, conforme possibilita inferir que unidades de GP que despendem maior tempo com atividades operacionais possuem um baixo nível de inserção (Araújo, 2018; Buyens \& De Vos, 2001). "Recursos organizacionais", sobretudo a qualificação dos gestores da organização, foi considerado como um entrave ao processo de inserção, pois os gestores não têm os conhecimentos necessários (visão sistêmica) para compreensão dos macro processos organizacionais. Porém, o que é visto como barreira, também pode ser considerado uma oportunidade - pois, a partir dos limites cognitivos dos gestores, faz-se coerente que os líderes de GP controlem as informações para que as iniciativas de gestão estratégicas de pessoas tenham maior aderência e valorização (Sheehan, 2015; Buyens \& De Vos, 2001; Forester, 1984).

Conforme dito inicialmente sobre o contexto histórico da administração pública brasileira, evidenciou-se que as grandes alterações no funcionamento da máquina pública só foram possíveis graças à grupos da alta cúpula que aderiram a agendas reformistas (Costa, 2008; Lima, 1998; Bresser, 1997). O líder de GP que almeja posicionar no nível estratégico a unidade 
de gestão de pessoas deve aprender a jogar o jogo político, portanto, utilizando de suas diversas habilidades políticas. Habilidades como fomento a novas estruturas, persuasão, coalizão; mas sobretudo sua rede de contatos com executivos chave (Networking) e "Produção e Controle de Informações". Este controle que produz e divulga a relevância de suas iniciativas e, no fim, alinha a Gestão Estratégica de Pessoas com os objetivos organizacionais (Forester, 1984; Rua, 2014; Sheehan, 2006; Sheehan, 2016). 


\section{Considerações Finais}

O presente estudo teve como objetivo principal descrever o processo de inserção estratégica da área de Gestão de Pessoas de duas organizações do setor público e seus profissionais nas arenas decisórias. Para tal foi identificado o conteúdo abordado pela área de gestão de pessoas nas arenas e em seguida, foi identificado os fatores que facilitam ou dificultam a inserção estratégica da unidade de GP. Por fim, foram identificadas quais as habilidades políticas mais utilizadas pelo líder de GP para acesso às arenas decisórias.

A partir do relato dos entrevistados desta pesquisa, foi notada a influência de um contexto geral sobre o contingenciamento de gastos com pessoal na administração pública brasileira. Com base nesta demanda convergente dos órgãos, as iniciativas que as unidades de gestão de pessoas encaminharam às arenas visavam sanar este problema.

A análise dos resultados e da literatura, permite concluir que fatores como tempo de cargo - se baixo tempo, e visão sistêmica dos gestores (recursos organizacionais) são limitadores de pequeno peso para a inserção estratégica da área de pessoas. Ressalta-se, novamente, que a unidade de GP pode trabalhar uma mudança de cultura organizacional para o pensamento sistêmico em suas atividades operacionais e estratégicas. Já o impacto das divergências das agendas políticas dos atores decisórios (Configuração política da organização) e o excesso de papéis operacionais da unidade de GP (Coexistência do papel funcional) são fatores limitantes de forte peso ao processo de inserção estratégica.

Concomitante aos fatores limitantes, identificou-se que a relevância das informações produzidas pela unidade de GP (recursos da unidade de GP) é um facilitador do processo. Porém, são as habilidades políticas da liderança de gestão de pessoas que elevam as oportunidades de acesso às arenas decisórias. Evidenciou-se que o Produção e Controle de Informações e a construção - pelo líder de GP, de uma rede informal de relacionamento com os executivos chave (networking) são as habilidades mais comumente utilizadas. Contudo, outras habilidades como coalizão, fomento a novas arenas e persuasão; também são bastante utilizadas podendo serem exercidas conjuntamente pelos representantes do setor de GP.

No ponto de vista acadêmico, esta pesquisa contribui no aprofundamento da compreensão do fenômeno da inserção estratégica e seu impacto organizacional. De igual modo, os resultados enriquecem o debate dos fatores intervenientes das políticas de gestão 
estratégica, à medida que propicia iniciativas de combate às contingências políticas. Outro aspecto a ser ressaltado, foi o acréscimo de ricos e solidificados elementos do campo científico das Políticas Públicas à linha que fundamentou esta pesquisa. A partir dos resultados encontrados, alguns aspectos desta pesquisa possibilitam novos estudos.

Nesse sentido, como agenda de pesquisa, sugere-se o estudo das categorias de habilidade política em outros órgãos da administração pública, na busca de aperfeiçoa-las ou encontrar novas que exprimem de modo fidedigno a realidade. Outra possibilidade é a ampliação da amostra da pesquisa com os membros das arenas decisórias, pois capturar suas habilidades políticas permitiria melhor descrição das interações sociais na arena decisória.

Ademais, o estudo encontra limitações referentes a quantidade de dados coletados e amostra. O baixo número de entrevistas é um fator limitante da pesquisa, assim como o não acesso ao representante da unidade gestão de pessoas de uma das organizações. Outro aspecto foi a amostra de participantes recém alocados em seus cargos, fato que influenciou na qualidade dos dados coletados.

Diante do exposto, considera-se que a pesquisa fornece contribuições para a compreensão das complexas interações sociais existentes entre atores da administração pública brasileira, da mesma forma que propicia insumos para o entendimento e combate da contingência política da implementação de políticas e práticas de gestão estratégica de pessoal. A pesquisa convoca os líderes da unidade de pessoal do setor público, a interpretarem o complexo contexto que circunda a máquina pública - sobretudo o ambiente de competição das estruturas de poder, para fazerem frente aos malefícios que prejudicam o progresso do profissionalismo público brasileiro. A principal contribuição desta pesquisa é demonstrar que os representantes do setor de gestão de pessoas são agentes de transformação, pois - ao buscarem a constante inserção nos principais espaços de decisão, estes terão oportunidades de eleger iniciativas de elevado impacto benéfico para a sociedade. 


\section{Referências}

ABRUCIO, F. L. (1997). O impacto do modelo gerencial na administração pública: um breve estudo sobre a experiência internacional recente. Cadernos ENAP, 10, 52p.

ARAÚJO, Luciana Graziani Barbosa de. Gestão de desempenho no executivo federal: iniciativas de enfrentamento aos fatores intervenientes na implementação. 2018. 109 f., il. Dissertação (Mestrado em Administração)—Universidade de Brasília, Brasília, 2018.

BARDIN, L. (1977). Análise de conteúdo. São Paulo: Edições 70.

BAUER, Martin W., GASKELL, George (2002). Pesquisa qualitativa com texto, imagem e som: um manual prático. Petrópolis: Vozes, 2002.

BORGES, L. O. \& MOURÃO, L. (2013). O trabalho e as organizações: atuações a partir da psicologia. Porto Alegre: Artmed, 2013.

BRESSER, P. L. C. (1998). Uma reforma gerencial da administração pública no brasil. Revista do Serviço Público, nº 1, ano 49.

BUYENS, D. \& DE VOS, A. (2001). Perceptions of the Value of the HR Function. Human Resource Management Journal. 11. 70 - 89. 10.1111/j.1748-8583.2001.tb00046.x.

CAMÕES, M. R. S, PANJOTA, M. J \& BERGUE, S. T. (2010) Gestão de pessoas: bases teóricas e experiências no setor público. ENAP. Brasília, 2010.

CAMÕES, Marizaura Reis de Souza. Análise do processo de implementação da Política Nacional de Desenvolvimento de Pessoal. 2013. xii, 200 f. Dissertação (Mestrado em Administração)—Universidade de Brasília, Brasília, 2013.

CAMÕES, M. R. S, Fonseca, D. R. \& Porto, V. (2014) Estudos em gestão de pessoas no serviço público. Cadernos ENAP, 37.

CAMÕES, M. R. S. \& Meneses, P. P. M. (2016) Gestão de pessoas no governo federal: análise da implementação da política nacional de desenvolvimento de pessoal. Cadernos ENAP, 45, 104p. 
CASTRO, M. V. de M. (2018) Políticas e práticas estratégicas de gestão de pessoas em organizações públicas: Iniciativas organizacionais de favorecimento à implementação. (Dissertação de mestrado). Universidade de Brasília, Brasília, DF, Brasil.

CAVALCANTE, Pedro. (2017). Gestão Pública Contemporânea: do movimento gerencialista ao pós-NPM. IPEA. Brasília.

CÔRTES, Felipe Guimarães. Gestão estratégica de pessoas no Legislativo Federal: desafios e possibilidades. 2016. 286 f., il. Dissertação (Mestrado em Administração) —Universidade de Brasília, Brasília, 2016.

COSTA, Frederico Lustosa da. Brasil: 200 anos de Estado; 200 anos de administração pública; 200 anos de reformas. Rev. Adm. Pública, Rio de Janeiro, v. 42, n. 5, p. 829-874, Oct. 2008. Available from $\quad<$ http://www.scielo.br/scielo.php?script=sci_arttext\&pid=S003476122008000500003\&lng=en\&nrm=iso>. Access on 04 Apr. 2019. http://dx.doi.org/10.1590/S0034-76122008000500003.

COOPER, D. R., \& SCHINDLER, P. S. (2016). Métodos de Pesquisa em Administração - $12^{\mathrm{a}}$ Edição. McGraw Hill. Brasil.

CRESSWELL, John W. (2007). Projeto de pesquisa: métodos qualitativo, quantitativo e misto. 3ed. Porto Alegre: Artmed

DAGNANO, Renato et alii (2002): gestão estratégica da inovação: metodologias para análise e implementação. taubaté, editora cabral universitária.

DIAS, Reinaldo; MATOS, Fernanda. Políticas Públicas - Princípios, Propósitos e Processos. São Paulo: Atlas, 2012.

DYER, L. (1983), Bringing human resources into the strategy formulation process, Human Resource Management, Vol. 22 No. 3, pp. 257-71.

FLICK, U. (2009) Introdução à Pesquisa Qualitativa. Trad. Joice Elias Costa. 3. Ed. Porto Alegre: Artmed.

FONSECA, Diogo Ribeiro da. Análise da implantação da gestão por competências em agências reguladoras federais. 2011. 100 f. Monografia (Bacharelado em Administração) -Universidade de Brasília, Brasília, 2011. 
Fonseca, D. R. (2013). Autonomia de unidades de gestão de pessoas para desempenho das atividades estratégicas de capacitação na Administração Pública Federal (Dissertação de mestrado). Universidade de Brasília, Brasília, DF, Brasil.

FORESTER, J. (1984) Bounded rationality and the politics of muddling through. Public Administration Review, Vol. 44, No. 1.

GIL, A. C. (2008). Métodos e Técnicas de Pesquisa Social (6th ed.). São Paulo: Atlas.

HOWLETT, Michael; RAMESH, M. \& PERL, Anthony. (2013). Política Pública: seus ciclos e subsistemas: uma abordagem integral. Rio de Janeiro: Elsevier, 2013.

LIMA JR., O. B. 1998. As reformas administrativas no Brasil: modelos, sucessos e fracassos. Revista do Serviço Público, Brasília, v. 49, n. 2, p. 5-31, abr.-jun.

LACOMBE, B. M. B., CHU, R. A. (2008). Políticas e Práticas de Gestão de Pessoas: As abordagens estratégica e institucional. Revista de Administração de Empresas, 28(1), 25-35.

LACOMBE, B.M.B., TONELLI, M.J. O discurso e a prática: O que dizem os especialistas e o que mostram as práticas das empresas sobre os modelos de gestão de Recursos Humanos. Revista de administração contemporânea, Curitiba, V.5, n.2, p.157-174, maio/ago. 2001.

Lengnick-Hall, M. L., Lengnick-Hall, C. A., Andrade, L. S., \& Drake, B. (2009). Strategic human resource management: the evolution of the field. Strategic Human Resource Management, 19, 64-85.

LIPSKY, Michael. Street-level Bureaucracy: dilemmas of the individual in public services. New York: Russel Sage Foundation, 1980.

LONGO, F. Mérito e Flexibilidade: A gestão das pessoas no setor público. São Paulo: FUNDAP, 2007.

LOTTA, Gabriela. O papel das burocracias do nível da rua na implementação de públicas: entre o controle e a discricionariedade. In: FARIA, C. A (org). Implementação de Políticas Públicas. Teoria e Prática. Editora PUCMINAS, Belo Horizonte, 2012.

LOWI, Theodore J. American Business, Public Policy, Case-Studies, and Political Theory. World Politics, v. 16, n. 4, p. 677-715, 1964.

_. Theodore J. Four Systems of policy, politics and choice. In: Public Administration Rewiew, v. 32, n. 4, 1992. 
MARCONI, N. (2010). A gestão de recursos humanos no governo federal: diagnóstico e proposta. Digesto Econômico, n. 457, p. 80-98.

MARLER, J. H., \& Fisher, S. L. (2013). An evidence-based review of e-HRM and strategic human resource management. Human Resource Management Review, 23, 18-36.

MARTINS, H. F. (1997). Burocracia e a revolução gerencial - a persistência da dicotomia entre política e administração. Revista do Serviço Público, 48(1), 42-78. Disponível em: http://repositorio.enap.gov.br/handle/1/1424

MARTINS, Luciano. (1995). Reforma da administração pública e cultura política no Brasil: uma visão geral. Série monográfica: Cadernos ENAP, 08. Disponível em: http://repositorio.enap.gov.br/handle/1/1748

MATIAS-PEREIRA, J. (2008). Administração pública comparada: uma avaliação das reformas administrativas do Brasil, EUA e União Europeia. Revista de Administração Pública, 42(1), 61-82.

MINAYO, Maria Cecília. S.(org.). Pesquisa Social: teoria, método e criatividade. $32^{\circ}$ edição. Petrópolis (RJ): Vozes, 2012.

MONTEIRO, Jorge Vianna. (2006). Coletânea de políticas públicas: volume 1: o processo decisório de política. ENAP. Disponível em: http://repositorio.enap.gov.br/handle/1/1258

MOTTA, Paulo Roberto de Mendonça. O estado da arte da gestão pública. Rev. adm. empres., São Paulo , v. 53, n. 1, p. 82-90, Feb. 2013 . Available from $<$ http://www.scielo.br/scielo.php?script=sci_arttext\&pid=S003475902013000100008\&lng=en\&nrm=iso>. access on $04 \quad$ Apr. 2019. http://dx.doi.org/10.1590/S0034-75902013000100008.

MOURA, A. L. N.; SOUZA, B. C. Gestão estratégica de pessoas na administração indireta do setor público federal: na prática, ainda um discurso. Revista do Serviço Público, v. 67, n. 4, p. 575-602, 2016.

ONU (2008). A gestão de pessoas como um recurso estratégico. Departamento de assuntos econômicos e sociais. Revista do Serviço Público - RSP, v. 57, n. 3, p. 389-426. http://repositorio.enap.gov.br/handle/1/1403 
REIS, Bruno P. W.. Arena Política. In: Geraldo Di Giovanni; Marco Aurélio Nogueira. (Org.). Dicionário de Políticas Públicas. 1ed.São Paulo, SP: Ed. FUNDAP; Imprensa Oficial do Estado de São Paulo, 2013, v. 1, p. 1-1.

RUA, M. G. Políticas Públicas - 3. ed. rev. atua. - Florianópolis : Departamento de Ciências da Administração / UFSC; [Brasília] : CAPES : UAB, 2014. 130p. : il.

ROCHA, Ana Angélica B. M. A importância da implementação para a análise das políticas públicas. Pensamento \& Realidade, São Paulo, ano XV, v. 27 n 1/2012, p.3-16. Disponível em: http://revistas.pucsp.br/index.php/pensamentorealidade/article/view/11521/8337

SECCHI, Leonardo. Modelos organizacionais e reformas da administração pública. Rev. Adm. Pública, Rio de Janeiro , v. 43, n. 2, p. 347-369, Apr. 2009 . Available from $<$ http://www.scielo.br/scielo.php?script=sci_arttext\&pid=S0034-

76122009000200004\&lng=en\&nrm=iso>. access on $04 \quad$ Apr. 2019. http://dx.doi.org/10.1590/S0034-76122009000200004.

SECCHI, Leonardo. Políticas Públicas: Conceitos, Esquemas de Análise, Casos Práticos. São Paulo: Cengage Learning, 2010.

SHEEHAN, C. (2005). A model for HRM strategic integration. Personnel Review, 34(2), 192209. https://doi.org/10.1108/00483480510579420

SHEEHAN, C., Cooper, B., Holland, P., \& Cieri, H. de. (2007). The relationship between HRM avenues of political influence and perceived organizational performance. Human Resource Management Review, 46(4), 611-629.

SHEEHAN, C., De Cieri, H., Cooper, B., \& Shea, T. (2016). Strategic implications of HR role management in a dynamic environment. Personnel Review, 45(2), 353-373. https://doi.org/10.1108/PR-04-2014-0071

SHEEHAN, Cathy \& De Cieri, Helen \& K Cooper, Brian \& Brooks, Robert. (2015). The impact of HR political skill in the HRM and organisational performance relationship. Australian Journal of Management. 41. 10.1177/0312896214546055.

SOUZA, C. Políticas Públicas: uma revisão da literatura. Sociologias, n.16, p.20-45, 2006.

SILVA, Maria O. S. et al. Pesquisa Avaliativa: aspectos teóricos-metodológicos. São Paulo: Veras Editora, 2013. 
TERABE, C. P. A. R., \& BERGUE, S. T. (2014). Gestão estratégica de pessoas como política pública: estudo de caso no ministério da ciência, tecnologia e inovação. In: Camões, M. R. S, Fonseca, D. R. \& Porto, V. Estudos em gestão de pessoas no serviço público. Cadernos ENAP, 37.

WILSON, W. (1887) - “The study of administration”. Political Science Quarterly, Vol. 2, (2), pp. 197-222. 


\section{Apêndice A - Roteiro de entrevista semiestruturado}

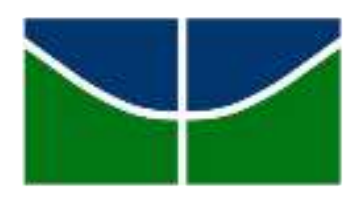

Universidade de Brasília
Faculdade de Economia, Administração, Contabilidade e
Gestão de Políticas Públicas
Graduação em Gestão de Políticas Públicas

O presente roteiro é uma ferramenta de auxílio à pesquisa para a coleta de dados do Trabalho de Conclusão de Curso do aluno Giullio César da Silva Barbosa da Universidade de Brasília, matrícula 15/0127987, sob a orientação do Prof. Doutor Pedro Paulo Murce Meneses. As informações coletadas através deste instrumento serão utilizadas em caráter estritamente acadêmico. A solicitação de sigilo das informações prestadas será respeitada.

No objetivo de descrever o processo de inserção estratégica da área de Gestão de Pessoas e seus profissionais nas arenas decisórias de duas organizações públicas. O fenômeno da inserção é definido como a presença da unidade de GP nas arenas decisórias, com liberdade para discutir, formular, monitorar e revisar propostas para a área.

Perfil do entrevistado

\begin{tabular}{l|l} 
Organização & \\
\hline Setor do qual faz parte & \\
\hline Cargo & \\
\hline Tempo no cargo & \\
\hline
\end{tabular}

\section{Seção 1 - Sobre as políticas de GP discutidas nas arenas decisórias}

1. Sobre questões referentes à Gestão de Pessoas, quais justificativas você julga relevante que a área de GP esteja presente nas arenas decisórias?

2. Nas arenas decisórias, quais políticas têm sido - ou foram, abordadas com maior frequência pela área de GP? E quais políticas foram demandadas pelos membros da arena à área? 
3. As informações/conteúdo acerca das políticas de GP em debate são produzidas somente pelo setor de GP? Há outros setores/atores que também apresentam informações acerca das políticas? Dê exemplos.

4. Se há outros setores/atores, qual a opinião destes atores acerca das informações/conteúdo sobre as políticas apresentadas pelo setor de GP? Eles consideram relevantes?

5. E o representante/líder de GP, considera as informações/conteúdo sobre as políticas apresentadas pelo outro setor/ator relevante?

6. Há atores (superior imediato ou pares) que contestam/não concordam acerca das informações/conteúdo apresentadas pelo representante/líder de GP? Se sim, qual a atitude do representante de GP frente a contestação/não concordância? Dê exemplos.

7. E no caso contrário, o representante de GP contesta/não concorda com as informações/conteúdos apresentados pelos demais atores. Qual a atitude desses atores frente a sua contestação/não concordância? Dê exemplos.

\section{Seção 2 - Compartilhamento de soluções de GP}

1. A solução/ideia de um determinado problema - que pode resultar numa nova política ou reformulação de uma política existente, é identificada pelo líder e/ou servidores da área de GP. De que forma esta solução/ideia é compartilhada para a organização/dentro e fora das arenas decisórias? Dê exemplos.

2. Em relação as soluções/ideias que foram compartilhadas pelo representante/líder de GP dentro e fora das arenas decisórias, qual o nível de aceitação dessas soluções/ideias?

3. Quais fatores dificultam a aderência de novas soluções/ideias da área de GP pela organização?

4. O representante/líder de GP já ofereceu alguma solução para uma política que - a priori, não era responsabilidade da área? Dê exemplos.

5. O setor/líder de GP contém parceiros/aliados para a difusão destas ideias/soluções?

6. De que forma o setor/líder de GP faz para conseguir novos parceiros/aliados aderentes a ideia? Dê exemplos.

\section{Seção 3 - Fomento a construção de novas estruturas decisórias}

1. Sobre as atuais e principais arenas decisórias, quais as dificuldades que a área de GP percebe/compartilha sobre a composição/estrutura destas arenas?

2. Outros setores compartilham das mesmas dificuldades de composição/estrutura às arenas decisórias? Dê exemplos 
3. Com vista a melhorar a composição das arenas decisórias e os processos decisórios, a área de GP já expôs - com ou sem a participação de outros setores, alguma solução ou nova configuração destas arenas?

a) Se sim, qual a nova configuração e de que forma a área expôs?

b) Se não, por que?

4. Se sim - além de exemplos, como esta nova configuração/solução foi percebida pela organização? Ela foi adotada? 


\title{
Apêndice B - Carta de Apresentação à Pesquisa
}

\author{
Ao Senhor [...] [Gestor]
}

Cumprimentando-o cordialmente, gostaria de me apresentar e expor a seguir; a pesquisa que estou realizando na Organização X.

1) Meu nome é Giullio César da Silva Barbosa, sou estudante de graduação do curso de Gestão de Políticas Públicas ( $9^{\circ}$ Semestre) da Universidade de Brasília/UnB, com matrícula 15/0127987;

2) Integro o grupo de pesquisa Projectum - Metodologias de Gestão, Centro de Pesquisa e Desenvolvimento. Este grupo busca criar e implementar modelos de gestão de última geração para alavancar a produtividade e eficiência operacional de organizações públicas e privadas. O grupo é coordenado pelo Prof. Dr. André Luiz Marques Serrano e pelo meu orientador, Prof. Dr. Pedro Paulo Murce Meneses.

3) A pesquisa da qual estou desenvolvendo integra a agenda do Centro de Pesquisa e Desenvolvimento de Políticas Estratégicas de Pessoas no Setor Público (CePGP), Grupo de Pesquisa coordenado pelo meu orientador, o Prof. Dr. Pedro Paulo Murce Meneses. O grupo busca contribuir com o desenvolvimento científico e profissional da área de gestão de pessoas no contexto do setor público brasileiro.

4) Meu Trabalho de Conclusão de Curso intitulado: "o fenômeno da inserção estratégica da área de gestão de pessoas: alinhamento entre políticas e práticas de gestão de pessoas e as diretrizes organizacionais em organizações públicas". A inserção estratégica é definida como a presença da unidade de Gestão de Pessoas (GP) nas arenas decisórias, com liberdade para discutir, formular, monitorar e revisar propostas para a área. $\mathrm{Na}$ finalidade de buscar a eficácia na implementação de políticas de GP, esta pesquisa tem por objetivo descrever o processo de inserção estratégica da área de Gestão de Pessoas e seus profissionais nas arenas decisórias de duas organizações públicas. Para isso será necessário: identificar o conteúdo abordado pela área de GP nas arenas decisórias, identificar os fatores que facilitam ou impendem a inserção, etc.

5) A atual etapa do trabalho será desenvolvida por meio da coleta de impressões e opiniões de gestores da área de Gestão de Pessoas da organização selecionada para o estudo, bem como das arenas decisórias desta organização a fim de descrever o fenômeno da inserção estratégica. Para isso, a abordagem de coleta adotada será a realização de entrevistas individuais semiestruturadas, com duração prevista de uma hora, a depender das respostas fornecidas.

6) É importante ressaltar que serão respeitadas todas as solicitações de sigilo de informações, não se fazendo necessárias a identificação das pessoas envolvidas. $\mathrm{O}$ assunto abordado somente será discutido no âmbito de grupos de estudo e da banca de 
análise do trabalho. De forma alguma faremos uso do material de maneira diferente do acordado ou a comprometer a organização e a equipe.

7) Apresentadas as motivações dessa pesquisa, caso seja de anuência de Vossa Senhoria a contribuição para essa pesquisa, solicito-lhe, por gentileza, indicar os dias e horários que melhor se adequam aos trabalhos de seu setor e dos possíveis participantes, em que eu poderia me apresentar para a coleta dos dados.

8) Para contatar-me, é possível utilizar o telefone (61) XXXX-XXXX ou o endereço eletrônico cesargiulliobol@gmail.com. Para contatar o meu orientador, é possível utilizar o endereço eletrônico pemeneses@yahoo.com.br.

Obrigado,

Atenciosamente, e desde já obrigado,

Giullio César da Silva Barbosa

Discente em Gestão de Políticas Públicas 


\title{
Apêndice C - Termo de Consentimento Livre e Esclarecido
}

\author{
Universidade de Brasília

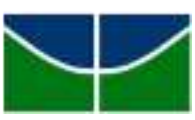 \\ Faculdade de Economia, Administração, Contabilidade e Gestão de \\ Políticas Públicas \\ Graduação em Gestão de Políticas Públicas \\ Termo de Consentimento Livre e Esclarecido (TECLE)
}

Título do Projeto: O fenômeno da inserção estratégica da área de gestão de pessoas: alinhamento entre políticas e práticas de gestão de pessoas e as diretrizes organizacionais em organizações públicas

Pesquisador Responsável: Giullio César da Silva Barbosa

Orientador: Prof. Dr. Pedro Paulo Murce Meneses

Telefones para contato: (61) XXXX-XXXX / (61) XXXX-XXXX

Convidamos Vossa Senhoria a participar da Pesquisa intitulada o fenômeno da inserção estratégica da área de gestão de pessoas: alinhamento entre políticas e práticas de gestão de pessoas e as diretrizes organizacionais em organizações públicas, sob a responsabilidade do pesquisador Giullio César da Silva Barbosa, a qual pretende descrever o processo de inserção estratégica da área de Gestão de Pessoas e seus profissionais nas arenas decisórias de duas organizações públicas

A participação é voluntária e se dará por meio de entrevistas, conduzidas em seu próprio local de trabalho. Serão obtidas cópias gravadas do áudio produzido durante essas ocasiões de coleta de dados, de forma a facilitar a transcrição e análise posteriores.

Caso Vossa Senhoria aceite participar, estará contribuindo para a melhor compreensão atuação das áreas de Gestão de Pessoas no processo de tomada de decisões nas organizações públicas, questões ainda muito pouco exploradas academicamente.

Após consentir em participar, caso Vossa Senhoria desista de continuar participando, tem o direito e a liberdade de retirar seu consentimento em qualquer fase da pesquisa, seja antes ou depois da coleta dos dados, independente do motivo e sem nenhum prejuízo a sua pessoa. A participação não gerará nenhuma despesa e também não ensejará nenhuma remuneração. Os resultados da pesquisa serão analisados e publicados, mas a identidade dos participantes não será divulgada, sendo guardada em sigilo. Para qualquer outra informação, o pesquisador e seu orientador estão à disposição por meio dos contatos informados.

\section{Consentimento Pós-Informação}

$\mathrm{Eu}$, ,fui informado sobre as atividades que o pesquisador pretende conduzir e porque precisa da minha colaboração, entendendo a explicação. Por isso, eu concordo em participar do projeto, sabendo que não vou ganhar nada e que posso sair quando quiser. Este documento é emitido em duas vias, que serão ambas assinadas por mim e pelo pesquisador, ficando uma via com cada um de nós.

Assinatura do participante

Assinatura do pesquisador responsável

Brasília,

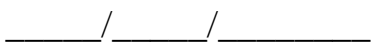

